\title{
USO E DIVERSIDADE GENÉTICA EM POPULAÇÕES NATURAIS DE BIRIBA (ESCHWEILERA OVATA [Cambess.] Miers): SUBISÍDIOS AO MANEJO E CONSERVAÇÃO DA ESPÉCIE
}

\section{EDUARDO GUSSON}

\author{
Dissertação apresentada à Escola Superior de \\ Agricultura "Luiz de Queiroz" Universidade de São \\ Paulo, para obtenção do título de Mestre em Ecologia \\ de Agroecossistemas.
}

P I R A C I C A B A

Estado de São Paulo - Brasil

Novembro - 2003 


\section{USO E DIVERSIDADE GENÉTICA EM POPULAÇÕES NATURAIS DE BIRIBA (ESCHWEILERA OVATA [Cambess.] Miers): SUBISÍDIOS AO MANEJO E CONSERVAÇÃO DA ESPÉCIE}

\section{EDUARDO GUSSON}

Engenheiro Florestal

Orientador: Prof. Dr. PAULO YOSHIO KAGEYAMA

Dissertação apresentada à Escola Superior de Agricultura "Luiz de Queiroz" Universidade de São Paulo, para obtenção do título de Mestre em Ecologia de Agroecossistemas.

P I R A C I C A B A

Estado de São Paulo - Brasil

Novembro - 2003 
Dados Internacionais de Catalogação na Publicação (CIP) DIVISÃO DE BIBLIOTECA E DOCUMENTAÇÃO - ESALQ/ USP

\author{
Gusson, Eduardo \\ Uso e diversidade genética em populações naturais de biriba (Escweilera \\ ovata [Cambess.] Miers) : subsídios ao manejo e conservação da espécie / \\ Eduardo Gusson. - - Piracicaba, 2003. \\ $91 \mathrm{p}$. \\ Dissertação (mestrado) - - Escola Superior de Agricultura Luiz de \\ Queiroz, 2003. \\ Bibliografia. \\ 1. Biriba 2. Conservação genética 3. Diversidade genética 4. Ecologia \\ florestal 5. Eletroforese 6. Manejo florestal 7. Mata Atlântica I. Título
}

CDD 634.94 


\section{AGRADECIMENTOS}

Inicialmente agradeço ao prof. Paulo Kageyama, meu mestre da arte florestal, por sua orientação, apoio e contribuição para a realização deste trabalho, impulsionando meu desenvolvimento cientifico e profissional, e pela boa amizade ao longo de alguns anos de convivência.

Ao pesquisar Alexandre Sebbenn, pela grande contribuição nas análises genéticas e discussão dos resultados, as quais foram muito enriquecedoras, possibilitando darboa qualidade ao trabalho, e a Rita, pela hospitalidade nos prolongados dia de trabalho em sua casa.

A pesquisadora Maria Beatriz Perecin, pelas sugestões e críticas e aceite de participação na composição de minha banca.

Ao camarada Leonardo, conhecedor do ambiente cultural e ambiental de Salvador, o qual contribui grandemente para o desenvolvimento logístico deste trabalho, juntamente a Ana, pela hospitalidade em suas terra natal.

Aos técnicos do LARGEA, Andréia, Gelson e Elza, pela colaboração nos exaustivos dias de trabalho, e a todos os estagiários que passaram pelo laboratório.

Aos amigos pós-graduando do LARGEA, Jõao, Cipó, Graciela, Renato, Edu, entre outros que eu possa ter esquecido de citar, que de formas diferenciadas colaboraram com na execusão deste projeto. Em especial ao Luciano, pela ajuda na leitura dos géis, e a Sybelle e Karina pelas críticas e sugestões finais do trabalho, grande saudação a todos.

Ao pessoal da Fundação Garcia D'Avila, pelo apoio logístico na coleta de campo 
na Reserva de Camarugipe, principalmente ao guias Biu, Jorge e Zé, com os quais pude trabalhar e aprender.

Agradecimento especial ao extrator Sr. Carlinhos, exímio conhecedor das matas de Itaparica e do manejo da biriba, pelo aprendizado e amizade nos exautivos dias de trabalho debaixo de muita chuva.

A meus camaradas do grupo da capoeira, pela manutenção das atividades na minha ausência e pela compreensão da situação, forte abraço a todos.

A meus filhos Lucas e Júlia e minha esposa Teresa, dos quais tanto me ausentei durante longos dias de trabalho noturno e finais de semana, muita paz em nossos caminhos.

Eternos agradecimentos a meus pais Aldo e Marlene e familiares pela liberdade em minha formação na escola da vida e apoio em todos os momentos.

E a quem mais esteve comigo durante este período que, por motivos alheio a minha vontade, deixo de citar. 


\section{Dedico}

a todas as pessoas que possam vir a ler este trabalho

$$
\text { e tirar algum proveito de seu conteúdo }
$$




\section{SUMÁRIO}

Página

AGRADECIMENTOS ....................................................................... iii

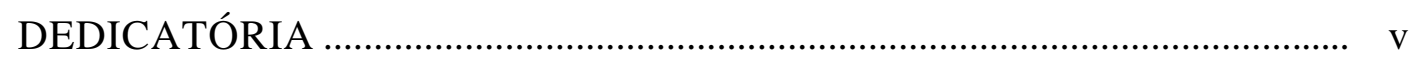

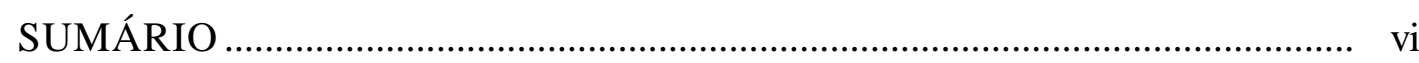

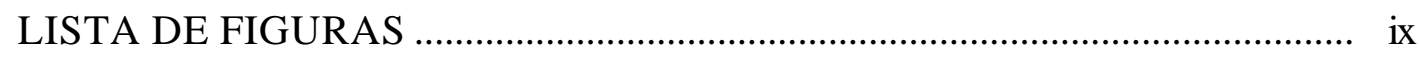

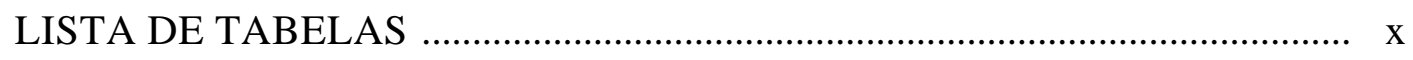

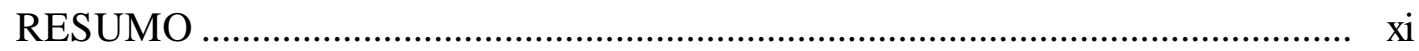

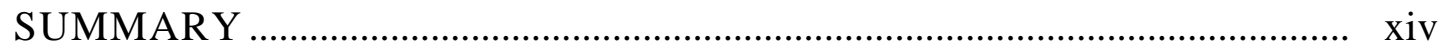

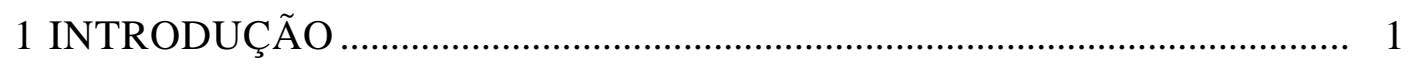

2 REVISÃO BIBLIOGRÁFICA _............................................................... 5

2.1 Manejo em floresta tropical por comunidades locais ............................... 5

2.2 Diversidade, raridade e dinâmica sucessional das espécies na floresta tropical e suas relações com o manejo florestal........................................... 8

2.3 Conservação in situ de recursos florestais .................................................. 12

2.4 Estrutura genética de populações .............................................................. 15

2.5 Estrutura espacial dos genótipos ............................................................. 16

2.6 Sistema de Reprodução de espécies arbóreas tropicais .............................. 17

2.7 Eletroferese de izoenzimas ....................................................................... 18

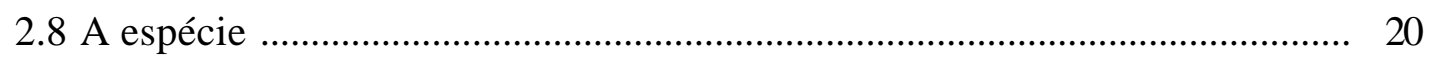

2.9 O Manejo tradicional da biriba por comunidades locais ............................ 24

3 MATERIAL E MÉTODOS …............................................................... 27 
3.1 Áreas de estudo

3.1.1 Caracterização da extração e comercialização de "biribas" em Itaparica ...... 31

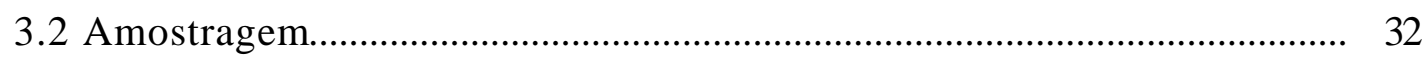

3.3 Protocolo de isoenzimas .......................................................................... 34

3.4 Análise estatística.............................................................................. 37

3.4.1 Sistema de reprodução....................................................................... 37

3.4.2 Diversidade genética intrapopulacional .................................................. 38

3.4.3 Estrutura genética ................................................................................ 39

3.4.3.1 Estrutura nas populações de adultos .................................................. 40

3.4.3.2 Análise individual das populações ......................................................... 40

3.4.3.3 Análise da variância conjunta das populações ..................................... 41

3.4.4 Distribuição espacial de genótipos.......................................................... 41

4 RESULTADOS E DISCUSSÕES ............................................................ 43

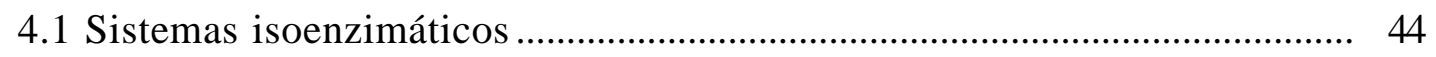

4.2 Sistemas de Reprodução........................................................................... 47

4.2.1 Teste de Equilíbrio de Hardy-Weinberg ................................................... 47

4.2.2 Desequilíbrio de ligação entre pares de locos ......................................... 48

4.2.3 Freqüências Alélicas dos Óvulos e do Pólen............................................. 49

4.2.4 Homogeneidade nas Freqüências Alélicas das Árvores das Populações adultas dos populações e Freqüências Alélicas dos Óvulos e Pólen .... 51

4. 2.5 Taxa de cruzame nto multiloco e uniloco ................................................ 52

4.2.6 Taxa de Cruzamento entre Parentes ........................................................ 55

4.2.7 Taxa de cruzamentos correlacionados ................................................... 56

4.2.8 Índices de Fixação............................................................................. 58

4.2.9 Coeficiente de coancestria e tamanho efetivo de variância .................... 59

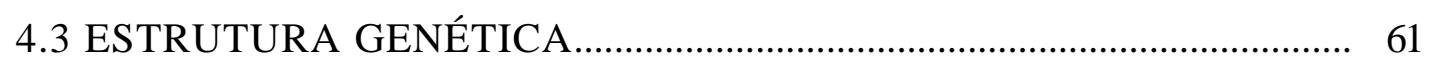

4.3.1 Freqüências alélicas .......................................................................... 61 
4.3.2 Distribuição da diversidade genética entre e dentro de populações ........ 63

4.3.2.1 Divergência genética entre populações................................................... 63

4.3.2.2 Distância genética entre populações....................................................... 64

4.3.3 Diversidade genética intrapopulacional .................................................. 65

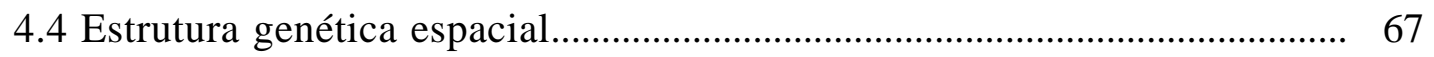

4.6 Subsídios ao manejo e a conservação genética de populações naturais de

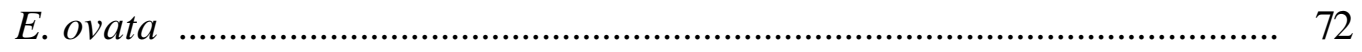

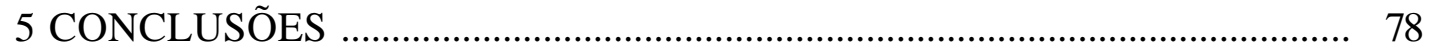

REFERÊNCIAS BIBLIOGRÁFICAS _........................................................ 79 


\section{LISTA DE FIGURAS}

Página

1 Mapa esquemático da localização das áreas de estudo

2 Distribuição por classes diamêtricas dos troncos dos indivíduos amostrados nas populações natural e manejada.

3 Amostras de géis de diferentes sistemas izoenzimáticos utilizados para a análise genética de E. ovata.

4 Representação esquemática da interpretação de bandas dos sistemas enzimaticos analisados para E. ovata.

46

5 Correlograma para o índ ice $I$ de Moran para o método do vizinho mais próximo por classes de distância na população Camarugipe, em E. ovata.

6 Correlograma para o índice $I$ de Moran para o método do vizinho mais próximo por classes de distância na população manejada de Itaparica, em E. ovata. 


\section{LISTA DE TABELAS}

Página

1 Probabilidades do teste exato de Fisher para o Equilíbrio de Hardy-Weinberg (EHW) em populações de Eschweleira ovata................................................... 48

2 Resumo do teste de qui-quadrado para ligação entre pares de locos, conjunto para ambas populações de progênies

3 Estimativa das frequiências alélicas, número total de alelos $\left(n_{a}\right)$ e tamanho amostral (n) do pólen e óvulos das progênies de Eschweleira ovata.

4 Estimativa da divergência genética entre as frequiências alélicas do pólen que fecundou as progênies, entre as freqüências alélicas das árvores adultas e os óvulos e entre as árvores adultas e o pólen em duas populações de Eschweleira ovata

5 Estimativa de parâmetros do sistema de reprodução em uma população de $E$. ovata.

6 Estimativa da taxa de cruzamento multiloco individual por planta materna $(\hat{t})$ em população de E. ovata. ( ): Intervalo de confiança, a 95\% de probabilidade pelo teste t de Student. [ ]: Erro padrão da média, obtido por 1.000 reamostragens bootstrap

7 Estimativa de freqüências alélicas em adultos e progênies de Eschweleira ovata.

8 Divergência genética entre populações e progênies 64 
9 Matriz de distâncias genéticas não viesadas de Nei (1978) (diagonal superior) e divergência genética entre populações .......................................................... 65

10 Índices de diversidade genética intrapopulacional e relação $\hat{N}_{e} / n$ em

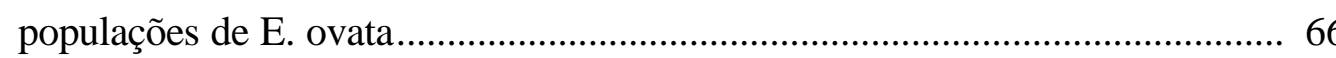

11 Coeficientes de autocorrelação espacial (Índice $I$ de Moran) obtidos nos 13 alelos de sete locos polimórficos, para 10 classes de distâncias na população de Camarugipe, em E. ovata.

12 Coeficientes de autocorrelação espacial (Índice $I$ de Moran), obtidos nos 13 alelos de sete locos polimórficos, para 10 classes de distâncias na população de Itaparica, em E. ovata. 


\title{
USO E DIVERSIDADE GENÉTICA EM POPULAÇÕES NATURAIS DE BIRIBA (ESCHWEILERA OVATA [Cambess.] Miers): SUBISÍDIOS AO MANEJO E CONSERVAÇÃO DA ESPÉCIE
}

\author{
Autor: EDUARDO GUSSON \\ Orientador: PROF. DR. PAULO YOSHIO KAGEYAMA
}

\section{RESUMO}

A exploração de produtos não madeireiro em florestas nativas tem sido alternativa na composição da renda de comunidades locais. Dentre as diversas espécies exploradas da Mata Atlântica, a biriba - Eschweilera ovata (Cambess.) Miers - vem sendo intensamente utilizada para a confecção do berimbau. Disponibilizar informações que auxiliem em apontar diretrizes para adequadas formas de conservação genética e manejo desta espécie é de fundamental importância, tanto do ponto de vista ecológico como econômico e social. Com este objetivo, realizou-se o estudo do sistema reprodutivo e da estrutura ge nética de E. ovata, através da técnica de eletroforese de isoenzimas, em três áreas de ocorrência natural de populações da espécie sob diferentes graus de antropização, sendo uma explorada e outras duas sem exploração, localizadas próximas à cidade de Salvador - BA. Os resultados do sistema de reprodução, obtidos para duas populações, mostram que a espécie reproduz-se predominantemente por cruzamento, tendo $\hat{t}_{m}$ variado de $98,5 \%$ a 99,9\%, valor este superior à média apresentada pelas espécies arbóreas tropicais. Uma certa taxa de cruzamentos endogâmicos foi 
evidenciada nas populações estudadas, sendo praticamente $100 \%$ da endogamia gerada nas progênies resultado de cruzamento entre parentes na população natural, e 76,8\% na população explorada, sendo o restante atribuído a autofecundação. $\mathrm{O}$ valor estimado para o coeficiente de coancestralidade dentro de progênies $\left(\hat{\boldsymbol{\theta}}_{F}\right)$ variou de 0,191 a 0,211. As estimativas das correlações de autofecundação $\left(\hat{r}_{s}\right)$, foram relativamente baixas em ambas as populações e não diferentes estatisticamente entre si, (variando de 0,100 a 0,107). O número provável de árvores doadoras de polén foi extremamente baixo, tendo em média, dois indivíduos por árvore matriz. O tamanho efetivo de variância $\left(N_{e(v)}\right)$ médio das populações foi de 2,13, sendo necessário assim, para reter o tamanho efetivo de 50, a coletas de cerca de 23 árvores nestas populações. O tamanho efetivo populacional foi próximo ao número de indivíduos amostrados. A divergência genética entre as populações de adultos $\left(\hat{\theta}_{p A}\right)$, foi de apenas $2,5 \%$,indicando que a maior parte da diversidade genética encontra-se distribuída dentro das populações (97,5\%). A divergência entre populações, estimada com base nas progênies $\left(\hat{\theta}_{p P}\right)$ foi ainda menor, de 1,4\% (0,1 a 3,5 O número médio de alelos por locos foi de 2,14 nos adultos e de 2,41 nas progênies. A porcentagem de locos polimórficos nas árvores adultas foi de 85,4\% e nas progênies de $81,8 \%$. A heterozigosidade esperada segundo as expectativas do Equilíbrio de Hardy-Weinberg (EHW) foram altas e variaram de 0,354 a 0,431, e a heterozigosidade observada variou de 0,332 a 0,371, sendo, tanto na progênies como nos adultos das populações, menor do que a heterozigosidade esperada, indicando que há mais homozigotos nas populações que o esperado pelas proporções do EHW. A análise de autocorrelação espacial das árvores de E. ovata dentro da populações estudadas mostrou haver estruturação, sendo que quanto mais próximos os indivíduos maior é probabilidade deles serem parentes. Os resultados obtidos possibilitaram realizar inferências a respeito da conservação e manejo da espécie.

PALAVRAS-CHAVES: diversidade genética; sistema reprodutivo; manejo florestal; eletroforese de isoenzimas; biriba (Eschweilera ovata). 


\title{
USE AND DIVERSITY GENETIC IN NATUAL POPULATIONS OF \\ BIRIBA (ESCHWEILERA OVATA [Cambess.] Miers): SUBSIDIES TO MANAGEMENT AND CONSERVATION OF SPECIE
}

\author{
Author: EDUARDO GUSSON \\ Adviser: PROF. DR. PAULO YOSHIO KAGEYAMA
}

\section{SUMMARY}

The exploitation of non-timber resources from tropical forest has been an alternative income to local human communities. Among the tree species which are exploited in the Atlantic forest, the "biriba" - Eschweilera ovata (Cambess.) Miers - has been used to manufacture the arc of "berimbau". The genetic conservation and the sustainable management of E. ovata populations are necessary to guarantee the longterm exploitation of this resource in an ecological, as well economic and social point of view. Adequate management strategies can be planned by getting information about the population genetic structure and mating system of the species. The aim of this study was to evaluate the mating system and the population genetic structure of E. ovata, using the allozyme electrophoresis technique. Three populations under different levels of human action in an area of natural occurrence of E. ovata near Salvador, Bahia state, were chosen. The results of the evaluation of the mating system of E. ovata, obtained for two population, indicate that the species reproduces itself through outcrossing. The outcrossing rate $\left(\hat{t}_{m}\right)$ varied from $98.5 \%$ to $99.9 \%$. These values are higher than that average estimates observed in tropical tree species. Inbred crosses were observed in the 
progenies. Almost $100 \%$ of the inbreeding observed in the non-disturbed population and $76.8 \%$ in the exploited population was due to crossing among related individuals. Selffertilization was also observed. The estimated value of the coefficient of the coancestrality among the progenies $\left(\hat{\boldsymbol{\theta}}_{F}\right)$ varied from 0.191 to 0.211 . The estimates of self-fertilization correlation $\left(\hat{r}_{s}\right)$ were low and statistically similar and non significant in both populations (the values varied from 0.100 to 0.107 ). The expected number of pollen donors was extremely low, having an average of two pollen donors by mother-tree. The average effective number of variance $\left(N_{e(v)}\right)$ was 2.13 . With this estimate was possible to conclude that it is necessary to collect about 23 adult trees in these populations to keep an effective size of 50 . The effective population size was similar to the number of individuals sampled. The genetic divergence among the adult populations $\left(\hat{\theta}_{p A}\right)$ was $2.5 \%$, showing the genetic diversity is mainly distributed within populations $(97.5 \%)$. The genetic divergence among the populations obtained from the progenies $\left(\hat{\theta}_{p P}\right)$ was also lower, $1.4 \%(0.1$ to $3.5 \%)$. The average number of alleles by loci was 2.14 in the adult populations and 2.41 in the progenies. The percentage of polymorphic loci was $85.4 \%$ in the adults and $81.8 \%$ in the progenies. The expected heterozigosity varied form 0.354 to 0.431 and the observed heterozigosity varied from 0.332 to 0.371 . The values of observed heterozigosity were inferior to the expected heterozigosity, indicating that there are more homozygous individuals than expected by the Hardy Weinberg Equilibrium. The spatial autocorrelation analysis of E. ovata shows that there is intrapopulational genetic structure in the studied populations of adult individuals. Closer individuals show a higher probability of being genetic related. The results obtained in this study are helpful to infer about the genetic conservation and the management of the species.

KEY WORDS: genetic diversity; mating system; forest management; isoezymes electrophoresis; biriba (Eschweilera ovata). 


\section{INTRODUÇÃO}

A redução dos ecossistemas tropicais, determinada pelos processos degenerativos resultantes da desordenada atividade humana sob estes ambientes, tem causado perdas inestimáveis desses repositórios de diversidade biológica, estando a Floresta Atlântica, representante de uma das mais complexa diversidade de espécie e altos índices de endemismo, entre os biomas mais ameaçados, restando atualmente cerca de apenas 7,3\% de sua cobertura original.

Esta região, caracterizada por pequenas áreas de remanescentes florestais isolados, é determinada pela forte ocupação populacional, abrigando em torno de $70 \%$ da população brasileira, a qual, de formas diversas, interagem com esses ambientes desde os primórdios de sua ocupação. Os diferentes graus de interferências nestes ambientes, que vão desde a utilização de seus recursos florestais à substituição desses complexos sistemas em sítios de produtividade monocultural, aliado ao isolamento dessas populações naturais, não representam boas perspectivas para a conservação, visto que a perda da diversidade genética e, conseqüente redução da capacidade de adaptação às mudanças ambientais, aumenta drasticamente as possibilidades de extinção de inúmeras espécies.

Particularmente na região costeira do nordeste, as modificações das paisagens naturais continuam apresentando riscos eminentes para várias espécies de plantas, das quais muitas são endêmicas (Mori et al., 1981). Como um agravante, essa região abriga centros secundários de distribuição para algumas famílias, destacando-se a Lecythidaceae, com algumas espécies de grande importância econômica (Mori, 1990; 1995).

A exploração de florestas nativas tem sido alternativa na composição da renda, seguindo, com poucas exceções, modos de extração desprovidos de qualquer estratégia 
de manejo que contemple tanto a necessidade de uso quanto da continuidade de populações geneticamente viáveis. Neste contexto, a necessidade de desenvolvimento de técnicas de exploração racional das florestas, através de formas de manejo sob regime de produção sustentada, é primordial para a conservação dos recursos florestais tropicais, além de ser exigência corrente nas atuais legislações ambientais.

Deve-se considerar que populações humanas vêm interagindo durante anos com a diversidade da floresta tropical e possuem valiosas informações de uso e manejo dos recursos florestais, inseridos em seus contextos culturais ,sendo elementos chave para entender, utilizar e proteger a biodiversidade local, porém, os impactos ecológicos e genéticos das técnicas locais deste manejo não são claramente explicitados.

O manejo sustentável necessita de parâmetros demográficos e genéticos que possibilitem subsidiar a elaboração dessas ações bem como o seu monitoramento no espaço e tempo. Porém a diversidade genética das espécies, um dos fatores primordiais a manutenção da vida nos ecossistemas tropicais, não tem sido considerada na quase totalidade dos programas de manejo, sendo estes baseados apenas em informações dendrométricas e demográficas.

Possíveis consequiências da exploração desordenadas das espécies nas florestas tropicais são alterações no seu comportamento dentro das populações, como: alteração do tamanho populacional; dos padrões espaciais e no comportamento dos polinizadores, afetando de forma negativa a estrutura genética de suas populações, podendo levar, por exemplo, à perda de alelos raros, à redução na heterozigosidade e na taxa de cruzamento, ao aumento da endogamia intrapopulacional e divergência entre populações. Estas alterações podem causar redução na aptidão e adaptação das gerações futuras, devido à erosão genética, colocando em risco a produção contínua e sustentada deste produto florestal e a conservação e manutenção da espécie, assim como dos ecossistemas que a abrangem.

Dentre as diversas espécies exploradas da Mata Atlântica, a biriba - Eschweilera ovata (Cambess.) Miers - vem sendo intensamente utilizada, entre outros usos, para a confecção do berimbau, sendo seu manejo inserido dentro de contextos culturais locais de sua área de extração. Comandando o andamento rítmico do jogo, o berimbau 
apresenta-se como indispensável na composição da orquestra de instrumentos nas rodas de capoeira, sendo acessório elementar, dotado de simbologias e fundamentos difundidos por antigos mestres desta arte, a qual, atualmente, possui grande número de praticantes em todo o mundo.

O uso da "biriba" para a confecção deste instrumento musical, por conferir instrumentos de ótima qualidade, é culturalmente tradicional, ligado intrinsecamente aos valores que regem o ambiente da capoeiragem. A mais, os incentivos ao turismo obtido pela Bahia nas últimas duas décadas, fortaleceram o comércio de acessórios que representem a marca de seu povo, sendo o berimbau um símbolo folclórico bastante apreciado pelos turistas que visitam este estado. Por esses motivos, a exploração de $E$. ovata vem se intensificando nos últimos anos, envolvendo um número significativamente grande de pessoas nas atividades relacionadas ao comércio do berimbau, que vai desde a extração da biriba até a comercialização do instrumento no mercado, tanto interno como externo, com um valor agregado alto.

A importância da manutenção das populações de E. ovata está sustentada não só na sua relevância ecológica, mas cultural, enquanto instrumento indispensável na realização da capoeira, elemento profundamente arraigado às tradições e identidade do povo brasileiro, e econômica, já que a extração e comercialização de caules da espécie, bem como do instrumento do qual é confeccionado, permite a captação de renda por uma parcela significativa de baianos, em sua maioria pequenos comerciantes, artesãos com micro empresas de estrutura familiar, extratores e capoeiristas (Pacheco, 2002 - não publicado).

O estudo de espécies utilizadas por populações tradicionais é de grande relevância, já que possibilita inferir sob a influência antrópica na estrutura ecológica e genética com base nas informações de manejo que estão presentes no contexto cultural dessas populações.

Propôs-se com este trabalho disponibilizar informações úteis à construção de modelo de manejo sustentável com respaldo à conservação genética de populações naturais de espécies arbóreas tropicais em áreas de florestas secundárias sob domínio da Mata Atlântica. Este foi realizado através do estudo genético de E. ovata, buscando 
identificar padrões no comportamento genético populacional desta espécie, em áreas sob diferentes condições de intervenção antrópica, localizadas no entorno da Grande Salvador - BA, com o objetivo de verificar se o manejo tradicional da espécie E. ovata nos ecossistemas naturais pode causar alteração nos padrões reprodutivos e na diversidade genética intra e interpopulacional.

Buscou-se com isso, dar continuidade à pesquisa sobre seu uso e subsídios técnicocientíficos para suprir a urgente necessidade de se ordenar e regulamentar a extração de caules desta típica espécie da Mata Atlântica, conforme discrimina o Artigo $2 \mathfrak{2}$ do Decreto 750 de 1993, que trata sobre o uso e a exploração dos recursos florestais deste bioma. Especificamente, este trabalho teve por finalidade:

1. estudar os padrões de reprodução desses tipos de populações por marcadores bioquímicos;

2. quantificar a diversidade genética entre e dentro de populações sob diferentes níveis de interferência antrópica;

3. verificar a existência de estruturação genética espacial nessas populações;

4. realizar inferências com base em indicadores genético-ecológicos que subsidiem o monitoramento da eficácia do manejo desta espécie. 


\section{REVISÃO BIBLIOGRÁFICA}

\subsection{Manejo em floresta tropical por comunidades locais}

A Mata Atlântica foi alvo de diferentes modos de ocupação humana conforme os ciclos econômicos e aspectos culturais e étnicos (Neves et al., 1999), sendo o histórico de ocupação destas áreas bem relatada no trabalho de Dean (1996) - A ferro e fogo: A História e a Devastação da Mata Atlântica Brasileira. Com cerca 93\% da cobertura original destruída e $80 \%$ destes remanescentes localizados em propriedade privada, seus recursos florestais são ainda alvo do extrativismo predatório, que vai da coleta seletivas de produtos não madeireiros, passando pela exploração de produtos madeiros, à substituição do uso da terra pela agropecuária, segundo Relatório para a Convenção sobre Diversidade Biológica do Brasil (Ministério do Meio Ambiente- MMA, 1998).

O artigo 10 da Convenção sobre a Diversidade Biológica (MMA, 1998), assinada durante a Conferência Rio-92, trata do uso sustentável da biodiversidade, atribuindo a seus signatários, entre outras, a tarefa de "adotar medidas econômica e socialmente racionais que incentivem à conservação e a utilização sustentável dos componentes da diversidade biológica, apoiando populações locais na elaboração e aplicação de medidas corretivas que minimizem os impactos na diversidade biológica".

Mais adiante, o Decreto $\mathrm{n}^{\circ}$ 750, de 10 de fevereiro de 1993, que dispõe sobre o corte, a exploração e a supressão de vegetação primária ou nos estágios avançado e médio de regeneração da Mata Atlântica, permite a execução de projetos de manejo de espécie da floresta atlântica, desde que seja de interesse social, podendo ser autorizado, mediante decisão motivada do órgão competente, quando fundamentados, entre outros aspectos, em estudos prévios técnico-científicos de estoq ues e de garantia de capacidade de manutenção da espécie alvo. Desta forma, fica evidenciado haver necessidade de 
desenvolvimento de pesquisas no campo do manejo florestal, voltados à utilização de recursos naturais deste bioma, para que se estabeleçam ações de manejo.

Lidar com a complexidade dos fatores sociais e suas interações com os fatores ambientais tem sido o grande desafio que se coloca para os que buscam entender e promover a sustentabilidade no uso dos recursos naturais, o qual exige um diálogo entre as ciências humanas, físicas e biológicas que ainda não se estabeleceu de fato (Teixeira, 2002). Neste sentido, esforços no campo da etnociência, vêm explicitando elementos de uma convivência dinâmica e sustentável, por vezes harmônica, estabelecida entre populações tradicionais e meio ambiente, via regimes de subsistência e de pequena produção mercantil (Neves et al., 1999), sendo este o tema de diversas reuniões cientificas. O uso de recursos vegetais de Mata Atlântica por populações tradicionais foi recentemente evidenciado por diversos autores (Begossi et al., 2001; Viana \& Diegues 2000; Simões, 2002). Estes usos podem estar relacionados de maneira mais complexa, englobando também a dinâmica florestal, não se restringindo apenas a espécies (Brookfield \& Padoch 1994; Balée 1989).

$\mathrm{Na}$ busca de formas de manejo sustentáveis para a conservação da biodiversidade, deve-se considerar que populações humanas que habitam florestas tropicais representam um dos componentes chave para entender, utilizar e proteger a biodiversidade tropical, pois são elas que interagiram durante séculos com a diversidade biológica presente nestes ambientes, possuindo as informações de uso e manejo presentes em seus contextos culturais. Considerar o conhecimento desta população na elaboração de planos de manejo e outras estratégias de conservação de espécies de uso comercial, pode ser fundamental para a garantia da manutenção das populações vegetais sem penalizar as comunidades locais que as tem como principal fonte de renda (Redford \& Padoch, 1992).

Com a crescente necessidade de alternativas econômicas para pequena produção, estes usos locais fazem com que esta diversidade de espécies tenha um potencial muito grande de aproveitamento, podendo servir como modelos para exploração sustentável de outras espécies (Cunningham, 2001). Assim, estudo do conhecimento dos extratores a respeito dos recursos naturais explorados é fundamental para a compreensão da 
dinâmica de extração e uso da espécie (Ellen, 1999), principalmente quando a espécie é explorada com a finalidade de atender a demanda comercial (Cunningham, 2001). Porém, apesar do conhecimento local sobre a grande maioria das espécies, os impactos ecológicos e genéticos das técnicas locais de manejo não são claramente explicitados (Cunningham, 2001).

A sustentabilidade dos programas de manejo só é possível quando inclui a manutenção dos processos dinâmicos característicos de cada comunidade florestal, garantindo a diversidade ambiental e biológica com suas intrínsecas interações, uma vez que a continuidade destes processos é a única forma de manter a estrutura das populações conservadas e produtivas por tempo indefinido nas florestas tropicais (Reis, 1993).

A manutenção de uma população sob manejo é dependente do recrutamento de novos indivíduos, independente da espécie ou do tipo de recurso explorado (Cunningham, 2001). Esses dados auxiliam na determinação de ciclos de exploração, que se apoiam na hipótese de que o crescimento da floresta deva ser igual ou superior à quantidade explorada da mesma. Porém, este modelo de manejo não considera um dos fatores primordiais para a manutenção da vida nos ecossistemas tropicais que é a diversidade genética das espécies - responsável pelas diferenças em produtividade, adaptação e reprodução entre indivíduos de uma espécie (Sebbenn et al., 2000).

Gandara \& Kageyama (1998) julgam fundamental para a conservação, manejo e recuperação do que resta da Floresta Tropical Atlântica, a junção dos conceitos de ecologia e genética de populações como forma de orientar as ações a serem efetuadas e definir parâmetros adequados para o monitoramento das mesmas. Neste sentido, Ratnam \& Boyle (2000) e Bawa \& Krugman (1994) argumentam que a exploração sustentada de florestas nativas necessita de estimativas confiáveis de parâmetros demográficos e genéticos que permitam a manutenção no espaço e no tempo das espécies exploradas. 


\subsection{Diversidade, raridade e dinâmica sucessional das espécies na floresta tropical e suas relações com o manejo florestal}

Biodiversidade refere-se à variedade natural em todos os níveis hierárquicos, desde do nível genético ao de ecossistemas, e toda a variabilidade existente dentro destes níveis, bem como de suas inter-relações ecológicas. Na Mata Atlântica, estima-se a existência de aproximadamente 20.000 espécies de plantas vasculares (Conservational International, 2003), das quais aproximadamente metade está restrita ao bioma. O trabalho de Reis (1993) contribui para compreender a divisão desta diversidade. Em estudo na Mata Atlântica de Santa Catarina, este autor identificou que o número de espécies arbóreas representa somente $35 \%$ das espécies vegetais, sendo as lianas e epífita representantes de $42 \%$ e as herbáceas e arbustos $23 \%$ do restante.

Kricher (1997), citado por Kageyama (2000), enfatiza que na floresta tropical a diversidade de espécies animais/microorganismos é cerca de 100 vezes a de vegetais, mostrando que a diversidade de espécie total aponta para uma intensa interação das plantas com outros organismos. Bawa (1985) constatou ser a maioria das espécies arbóreas tropicais $(97,5 \%)$ polinizadas por insetos, morcegos e beija-flores. Neste contexto, Estrada \& Fleming (1986) apontam para alta taxa de dispersão zoocórica de sementes nos ambientes tipicamente tropicais. Isto certamente prediz a existência de uma grande especiação, entre plantas e animais, resultante do processo de co-evolução dessas espécies. Do ponto de vista genético é o que possibilita entender as altas taxas de cruzamento, apontada por Kageyama (2001) com sendo acima de $90 \%$, e conseqüente diversidade genética das espécies arbóreas tropicais. Em vista esta imensa interação entre amimais e plantas, esta não pode deixar de ser considerada nos planos de manejo, já que a sustentabilidade destes está diretamente relacionada à manutenção desses complexos processos biológicos intrínsecos desses ecossistemas.

Kageyama (2000) atribui a alta diversidade de espécies da floresta tropical como um dos fatores responsáveis pela alta ocorrência de espécies raras, espécie com menos que 1 indivíduo por hectare, sendo estas a grande maioria das espécies arbóreas tropicais. De modo diferente, algumas espécies apresentam-se bastante adensadas, 
aparecendo com maior frequiência e abundância nos levantamentos fitossociológicos, recebendo a denominação de espécies comuns.

A raridade possibilita a coexistência de um maior número de espécie por área, podendo, segundo Schäffer (2002), ser encontrada mais de 450 espécies arbóreas em apenas1 ha de Mata Atlântica. Hubbell \& Foster (1986) em levantamento de 50 ha na Ilha de Barro Colorado, Panamá, demostram ser os indivíduos amostrados representantes de $75 \%$ das espécies da Ilha, a qual possui uma área de 1.5000 ha. $\mathrm{Na}$ amostragem de apenas 1 ha, foram representados apenas $43 \%$ de todas as espécies do total de espécies, tendo porém uma igual representatividade das famílias. Ainda neste sentido, Kageyama et al. (1991), em revisão de sete levantamentos fitossociológicos realizados no estado de São Paulo, verificou que 30\% das espécies se mostraram raras, ou com um só indivíduo na parcela, sendo estas, em média, pouco menores que 1 ha, enquanto $28 \%$ dos indivíduos pertenciam a somente três das espécies mais comuns.

Deve-se considerar que existe um gradiente na densidade das espécies nas comunidades, ocorrendo espécies com mais de 100 indivíduos adultos por hectare, até aqueles com 1 indivíduo adulto a cada 66 hectares (Kageyama et al., 1991 - não publicado). Torna-se evidente que em função das diferentes densidades de indivíduos, os mecanismos ecológicos e genéticos relacionados à manutenção desta espécie são, por vez, diferenciados.

Kageyama et al.(1991) comentam que embora existam espécies que podem apresentar variação em sua densidade de indivíduos dentro de sua região de ocorrência, a maioria das espécies arbóreas em florestas primárias ocorre em uma densidade mais ou menos fixa, estando esta densidade coerente com a distância de vôo dos polinizadores, o que é justificável, já que as arbóreas tropicais são preferencialmente alógamas. No caso, as espécies arbóreas raras seriam polinizadas por polinizadores de vôo longo e as comuns por polinizadores de vôo curto. Neste sentido, o fluxo gênico via pólen e sementes tem demostrado associado à estrutura genética das populações de espécies arbóreas tropicais, mostrando que a distância do vôo dos polinizadores e dispersores pode predizer a variação genética dessas espécies (Kageyama \& Lepsch-Cunha, 2001). 
Assim, as espécies raras apresentariam menor variação genética dentro, sendo maior entre populações, e menor taxa de cruza mento comparativamente às espécies comuns.

A distribuição desigual entre aos diferentes tipos de espécies é atribuída, segundo Kageyama \& Gandara (2000), aos processos de sucessão secundária, responsável pela contínua mudança na composição florística e e strutural da floresta. Este processo de cicatrização de clareiras em áreas naturais ou em locais perturbados é a forma pela qual as florestas se auto-renovam (GómezPompa, 1971). Essas clareiras são ocupadas por distintos grupos de espécies arbóreas, adaptadas para regenerarem em clareiras de diferentes tamanhos (Whitemore, 1982) Diferentemente da sucessão secundária, em áreas degradadas pela ação antrópica, ocorre uma sucessão diferenciada, especialmente quanto à origem das espécies iniciais (Pereira, 2002).

A separação das espécies em grupos sucessionais ou funcionais foi um catalizador de esforço de pesquisa de diversos autores (Budowski, 1965; Deslow, 1980; Whitemore, 1982; MartínezRamos, 1985; Gómez-Pompa, 1971; Bazzaz et al., 1980), e tem sido um instrumento de grande utilidade para o entendimento da dinâmica das florestas tropicais, bem como na elaboração de estratégias de regeneração de áreas desflorestadas (Kageyama \& Gandara, 2000). Uma forma muito habitual de separação das espécies é apresentada por Budowski (1965), classificando as espécies em 4 grupos sucessionais: pioneiras, secundárias iniciais, secundárias tardias e climácicas.

Tanto fatores naturais como antrópicos têm influenciado e modificado padrões de vegetação, em que se estabelece uma complexa interação entre fatores físicos, como topografia, pluviometria, e geologia, e fatores biológicos e sociais (Cunningham, 2001). Determinadas espécies que na floresta primária apresentam-se como raras, têm demostrado alterações em seu comportamento ao ocuparem áreas antropizadas. A exemplo disto, algumas espécies raras têm se tornado comuns, apresentando alta densidade de indivíduos, nesses ambientes antropizados. Esses desvios de seu comportamento vêm gerando confusão quanto à classificação das espécies em grupos sucessionais. Neste contexto, Kageyama \& Gandara (2000) consideram duas outras classes de classificação em grupos sucessionais, as das pioneiras antrópicas: espécies não tipicamente pioneiras na floresta primária, mas que fazem papel de pioneira em 
áreas degradadas, e secundárias/pioneiras Antrópica: espécies secundárias raras na floresta primária e que em área antrópicas fazem papel de pioneiras (Kageyama et al., 1994).

Os indicadores utilizados na separação das espécies nos diferentes grupos sucessionais provêm de uma série de características ecológicas como: velocidade de crescimento, tolerância à sombra, tempo de vida, dispersão e dormência de sementes, polinização, densidade de indivíduos, entre outras, que nos permite inferir sobre a dinâmica destes grupos nas comunidades/ecossistemas. O entendimento desta dinâmica ecológica, associada à questão da raridade das espécies tropicais, determina o comportamento da estrutura genética das espécies arbóreas tropicais. Estes conhecimentos são essenciais para apontar as potencialidades e limitações de manejo e conservação das espécies dos diferentes grupos sucessionais em seus ambientes naturais, sendo as espécies exploradas economicamente, em geral dos grupos finais da sucessão.

A raridade das espécies é característica marcante do grupo das secundárias tardias. Em levantamentos exaustivos de espécie deste grupo, estes têm indicado que estas espécies que são raras, apresentam curvas de freqüência de diâmetro seguindo uma curva normal de adultos, ño aparecendo indivíduos jovens nesses levantamentos, que contribuam estatisticamente, constatando-se apenas a ocorrência de plântulas em uma outra curva separada (Kageyama, 2000). Tal ocorrência é determinada pela forma de regeneração das espécies deste grupo que forma banco de plântulas temporários, as quais só serão recrutadas no ambiente se houver condições ambientais, determinadas por pequenas clareiras na floresta, suficientes para seu estabelecimento.

Como a maioria das espécies arbóreas da floresta tropical é rara, a probabilidade de uma plântula passar para a classe de jovens é um evento muito raro, o que explica a raridade dos adultos (Kageyama, 2000). Sendo o manejo florestal atual, principalmente os de produtos madeireiros, enfocado sobre um número limitado de espécies as quais são exploradas maximamente, ocorre uma limitação das fontes de propágulos de sementes, bem como a possibilidade de formação dos bancos de plântulas das espécies exploradas na área, reduzindo as possibilidades destas entrarem na composição dos novos indivíduos recrutados. Este é um dos principais motivos que tem gerado 
incertezas quanto a sustentabilidade do manejo nas florestas tropicais aos moldes praticados até o momento, conforme argumentado por Higushi \& Hummel (1997).

Um pressuposto básico para um possível manejo adequado de uma população é a existência de indivíduos jovens em quantidade e qualidade adequadas para repor, em um tempo predizível e econômico, a população a um patamar de uma nova exploração (Kageyama, 2000). Para esta ocorrência é requisito que a espécie sob manejo, apresente curva de frequiência de diâmetros do tipo "J invertido", ou seja, um grande número de indivíduos na classe dos jovens, reduzindo gradativamente para a classe dos adultos. Esta é uma característica típica do grupo das espécies climácicas, a exemplo da espécie Euterpe edullis (Reis, 1996).

Em se tratando da necessidade de manter as florestas e garantir, ao mesmo tempo, às comunidades locais o acesso a recursos de suma importância para sua subsistência, complementação de renda e bem-estar (Martin, 1995; Arnold \& Pérez, 2001), a exploração comercial de Produtos Florestais Não Madeireiros (PFNM) surge como uma alternativa de relevante importância ao manejo correlacionado à conservação das florestas tropicais (Pacheco, 2002 - não publicado), sendo este menos impactante.

\subsection{Conservação in situ de recursos florestais}

Diante a evidente necessidade de conservação da Floresta Tropical Atlântica, considera-se fundamental que ferramentas de análise que possibilitem inferir sobre as condições de conservação da biodiversidade deste bioma sejam explicitadas. Noss (1990) propõe o estudo da biodiversidade através da identificação de atributos e indicadores mensuráveis dentro dos diferentes níveis hierárquicos que a compõe, sendo estes representados pelos componentes genético, população/espécie e comunidade/ecossistema. O entendimento da composição, estrutura e função destes níveis serviriam para inventariar, monitorar e elaborar programas de conservação. Torna-se então, importante a definição do nível da informação que está se gerando, quando se busca apontar ferramentas para a compreensão e monitoramento da complexidade da diversidade da floresta tropical. 
Pereira (2002), expõe que entre os componentes da biodiversidade, os mais utilizados para gerar índices de diversidade são em nível de espécies e ecossistemas, principalmente relacionados à composição, de modo que muitas vezes espécies ou ecossistemas são alvo de extensos estudos e nem sempre representam o estado de conservação do bioma.

Redford \& Richter (1999) apontam o componente genético como sendo de grande sensibilidade ao uso humano. Do ponto de vista genético, tamanho efetivo populacional, estrutura genética espacial, diversidade e estrutura genética, fluxo gênico, entre outros, são aspectos que vem sendo estudados para inferir sobre o grau de conservação de populações de espécies nesses ambientes, sendo utilizado por diversos autores (Pereira, 2002; Sebbenn,2000; Ribas, 2003; Perecin,2000).

$\mathrm{Na}$ definição da eficiência no tocante à conservação dos recursos naturais, as teorias de metapopulação e ecologia de paisagem têm ganhado respaldo, não substituindo, mas sim acrescendo conceitos teóricos ao restrito contexto que abrangia as discussões a respeito dos SLOSS (single large ou several small). Estes conceitos consideram a questão do grau de isolamento dos fragmentos florestais e disposição destes na paisagem, levando em conta a conectivividade entre estas comunidades, estando a ciência gerando parâmetros confiáveis que possibilitam apontar para as expectativas de conservação in situ dos recursos naturais.

Deve-se considerar que a Floresta Atlântica encontra-se bastante fragmentada em sua paisagem original. Kageyama et al. (1998) propõem que para minimizar os efeitos genéticos e aumentar a probabilidade de manutenção das populações das espécies nos fragmentos, deve-se ter uma visão primeiramente da paisagem, e segundo, considerar o conceito de metapopulação. Dessa forma, o mosaico de fragmentos, o corredor de fluxo gênico, a distância mínima entre fragmentos pequenos, assim como os efeitos estocásticos de muitas gerações em várias sub-populações, são aspectos importantes para fundamentar teoricamente as ações.

Neste sentido, Kageyama (2001) argumenta que a efetividade da conservação in situ exige que se conheça a diversidade genética das populações das espécies, devendo haver um monitoramento dos padrões da variação genética ao longo do tempo. As 
principais consequiências teóricas da fragmentação e redução populacional, principalmente de espécies raras são: a deriva genética, aumento da endogamia e diminuição do fluxo gênico. Como estudar estes parâmetros de modo a gerar informações úteis é a essência para se realizar a conservação in situ na floresta tropical.

O uso de grupos de espécies de comportamento semelhante baseado em padrões ecológicos (status sucessional) e demográficos (densidade populacional), e de respostas à perturbação antrópica, são úteis para determinar padrões de espécies que apresentem característica e funções comuns, que podem também apresentar estruturas genética e populacional semelhantes (Kageyama et al., 2001). Estes comentam que o trabalho está em monitorar os parâmetros demográficos (abundância, distribuição etária ou crescimento, mortalidade) e genéticos (diversidade, taxa de cruzamento, autorelação espacial, etc) destas espécies, as quais são altamente dependentes das interações com outras espécies (polinização, dispersão de sementes, predação, competição, etc), de modo a apontar para a estabilidade da manutenção das interações de uma considerável parte da comunidade. Assim, os dados obtidos de poucas espécies modelo poderia ser extrapolados para boa parte da comunidade.

A influência antrópica na estrutura genética de espécies arbóreas tropicais assim como nos níveis de diversidade tem sido evidenciada (Ratnam \& Boyle, 2000). Uma proposta relevante e deve ser considerada é o estudo de espécies úteis que estejam sob regime de exploração, já que estas não só refletiria a influência antrópica na estrutura ecológica e genética, como minimizaria o problema de encontrar quais espécies seriam mais importantes para conservação, pois seu estudo e enriquecido com informações de manejo as quais já estão presentes no contexto cultural das populações humanas locais.

\subsection{Estrutura genética de populações}

Estrutura genética é definida como a distribuição não aleatória de alelos e genótipos dentro populações de espécies (Hamrick, 1983). O desenvolvimento e a manutenção da estrutura genética ocorrem devido às interações de um conjunto complexo de fatores evolucionários, com variação no conjunto gênico; organização desta variação dentro de genótipos; distribuição espacial dos genótipos; sistema de 
reprodução que controla a união dos gametas para a formação das progênies; dispersão das progênies; seleção; deriva; mutação; eventos casuais; e processos de crescimento, mortalidade e reposição dos indivíduos que darão origem às populações futuras $(\mathrm{Clegg}$, 1980; Hamrick, 1983; Loveless \& Hamrick, 1984; Hamrick, 1989). São ainda de importância fundamental o tamanho efetivo populacional, a seleção e a habilidade da espécie de dispersar pólen e sementes (Hamrick, 1983).

Hamrick (1983) aborda a necessidade do conhecimento da variabilidade genética tanto dentro como entre as populações para dar suporte à conservação dos recursos genéticos. Espécies que apresentam sistema misto de reprodução, mecanismos eficientes de dispersão de sementes e pólen, deverão apresentar alta variação genética dentro das populações e baixa entre estas (Loveless \& Hamrick, 1984). Já espécies com populações pequenas, de autofecundação e/ou reprodução vegetativa, com limitada dispersão de pólen e sementes, deverão mostrar baixa variabilidade dentro e alta entre as populações (Loveless \& Hamrick, 1984).

Neste sentido, Guries \& Kageyama (2000), indicam que tanto a densidade natural como o estágio sucessional afeta a estrutura genética das espécies. Baseado em dados preliminares, os autores apontam possuir as espécies raras, menor variação genética dentro de populações e menor taxa de cruzamento, comparativamente ás espécies comuns. As espécies pioneiras, por sua vez, apresentam menor variação genética e maior taxa de cruzamento do que as espécies não pioneiras.

Para Barret \& Kohn (1991), o importante é considerar o número de indivíduos que efetivamente realizam trocas gênicas, sendo este número geralmente diferente do tamanho real ou número senso da população. Esta ocorrência é devido a fatores como, flutuações temporais no número de indivíduos, cruzamentos direcionados, diferenciais de fertilidade e fluxo gênico entre populações. Frankel e Soulé (1983) comentam que grandes tamanhos populacionais são de suma importância para minimizar os riscos de extinção das espécies.

A redução no tamanho populacional, em função da fragmentação ou práticas predatórias de exploração, pode reduzir a variabilidade genética através da deriva amostral causada pelo gargalo genético. A deriva genética e o restrito fluxo gênico, 
provocam um acréscimo na endogamia promovendo um aumento da divergência genética entre populações. A endogamia pode levar a fixação de alelos recessivos deletérios, colocando em risco de extinção determinadas populações presentes em certos habitats (Young et al., 1996). A diferenciação entre as populações é aumentada pela seleção e deriva genética, sendo que espécies com intenso movimento de pólen e sementes, em geral, têm menor diferenciação do que espécies com fluxo gênico restrito (Hamrick, 1989)

Para Yeh (1988), a capacidade de regeneração e diversidade genética seriam dois pontos importantes para o desenvolvimento de um guia do manejo florestal sustentável e estratégias efetivas de conservação. Sebbenn et al. (2000) comentam que o manejo envolve alterações no tamanho populacional e nos padrões espaciais dentro das populações, variáveis que, dependendo da forma trabalhada, podem ter efeitos negativos sobre a estrutura genética das populações de uma espécie, como a perda de alelos raros, aumento da endogamia e redução na produtividade e adaptação das gerações futuras, colocando em risco o principal objetivo do manejo que é a produção contínua e sustentada dos produtos florestais Os referidos autores comparando uma população manejada com uma natural de Tabebuia cassinoides L. observaram redução nas heterozigosidades, taxa de cruzamento e aumento na endogamia das populações sob manejo. Também foram observadas perdas de alelos raros na população manejada.

\subsection{Estrutura espacial dos genótipos}

Gandara (1996) destaca a importância do conhecimento da estrutura genética espacial para o estabelecimento de estratégias de amostragem de populações naturais, tanto para a conservação genética quanto para fins de melhoramento, possibilitando a formação de amostras significativas. Cita, também, a importância deste conhecimento para minimizar o impacto de práticas de manejo na sustentabilidade dos recursos genéticos.

Estudos na estrutura intrapopulacional de espécies arbóreas têm demonstrado que a distribuição de alelos e genótipos não é aleatória dentro das populações. Tal estrutura pode ser determinada pela dispersão de pólen e sementes, habitat de distribuição e 
seleção micro ambiental (Hamrick, 1983). Isto porque a freqüência alélica na próxima geração, será influenciada pelo número de indivíduos que efetivamente trocarão alelos. Especialmente em pequenas populações, e a taxa de homozigotos tenderá a crescer com a autofecundação, os cruzamentos de indivíduos aparentados, e entre indivíduos similares que ficaram próximos em decorrência de dispersão de pólen e sementes a curta distância. Estes cruzamentos, segundo Whight (1978), proporcionam a formação de demes panmíticos e reduzem a proporção de heterozigotos na população, a qual pode ser quantificada pelo índice de fixação, a partir do teorema de Hardy-Weinberg.

Futuyma (1992) comenta que como em uma população existem limitações físicas que não permitem o cruzamento de todos com todos, ou seja, aleatória, devendo haver maior probabilidade de cruzamentos entre indivíduos próximos, o que gera a redução dos heterozigotos e formação dos grupos, estruturando a população.

\subsection{Sistema de reprodução de espécies arbóreas tropicais}

O estudo do sistema de reprodução permite estimar a taxa de cruzamento entre indivíduos, determinando o modo de transmissão de genes de uma geração à próxima (Brown,1990). Relevância é dada ao pioneiro trabalho realizado por Bawa (1974), que estudando o sistema de reprodução em espécies arbóreas tropicais da Costa Rica, através de polinização controlada e observações da biologia floral, verificou apresentarem, em um total de 130 espécies estudadas, 14\% espécies autocompatíveis, 54\% autoincompatíveis, $68 \%$ hermafroditas, $22 \%$ dióicas e 10\% monóicas. Marcadores isoenzimáticos ou moleculares vêm sendo utilizado com grande eficiência nos estudos de sistemas de reprodução em espécies arbóreas tropicais, as quais têm demostrado ser a grande maioria das espécies florestais alógamas ou de sistema misto, com predomínio de alogamia (O'Malley \& Bawa 1987, Murawski et al. 1990, Murawski, 1995).

Diferente das espécies predominantemente de autofecundação, onde a maior parte de sua variabilidade genética está distribuída entre populações, espécies de cruzamento mantêm a maior parte da variabilidade dentro e menor entre populações, (Hamrick 1983, Hamrick \& Godt, 1989), o que prediz maior heterozigosidade dentro e reduzidos níveis de divergência genética entre populações, devido ao intenso fluxo de 
pólen entre populações e grandes tamanhos efetivos e de vizinhança com reduzida subdivisão dentro de populações Sebbenn (2001). O sistema misto de reprodução prediz variabilidade genética intermediarias entre espécies de autofecundação e alógamas, sendo o potencial de diferenciação entre populações variável em função do balanço dessas duas formas de reprodução (Loveless \& Hamrick, 1984).

Dois modelos têm sido utilizados para caracterização dos sistemas de cruzamento, o modelo de cruzamento aleatório, e o modelo misto de reprodução, sendo o segundo o modelo mais difundido para avaliação do sistema de reprodução em plantas a partir de dados de marcadores genéticos (Clegg, 1980). As pressuposições básicas para a aplicação do modelo misto são: (a) os genótipos foram gerados por cruzamento aleatórios ou autofecundação; (b) as frequiências alélicas do pólen são homogêneas para todos os cruzamentos com genótipos maternos; (c) a taxa de cruzamento é independente do genótipo materno; e (d) não existe seleção atuando nos marcadores entre o período de cruzamentos e avaliação genética das progênies. (Ritland \& Jain, 1981; Ritland, 1990).

O sistema de reprodução, juntamente com os mecanismos de dispersão de pólen e sementes, tem papel fundamental na determinação da estrutura genética espacial e temporal das populações (Hamrick, 1983; Hamrick \& Lovelless, 1986). Portanto, o conhecimento da forma de reprodução de uma espécie é de fundamental importância em programas de melhoramento e conservação genética pois permite delinear estratégias que otimizem a amostragem da variabilidade genética e a adoção de modelos genéticosestatísticos adequados para a estimativa de parâmetros genéticos (Souza, 2003), e para determinar estratégias de manejo de populações em áreas naturais de modo que sejam mantidos os mecanismos de manutenção da diversidade genética das espécies.

\subsection{Eletroforese de isoenzimas}

Glaubitz \& Moram (2000) apresentam diversas aplicações dos marcadores genéticos na conservação genética dos recursos florestais, sendo estas: mensuração da diversidade genética e diferenciação em populações naturais e manejadas, estimativas das taxas de fluxo gênico ou migração, caracterização do sistema de cruzamento, análise 
de paternidade, avaliação da eficiência do pomar de sementes, estudos filogenéticos e taxonômicos, bem como quantificação e mapeamento de ligações genéticas.

Uma ferramenta que tem sido usada com grande eficiência para a análise do sistema reprodutivo e da estrutura genética de populações de espécies de plantas é a técnica de eletroforese de isoenzimas, tendo sido empregada na grande maioria dos estudos populacionais com plantas. A eletroforese de isoenzimas consiste na migração de moléculas ionizadas em um gel submetido à influência de um campo elétrico. A taxa de migração é determinada pelo tamanho, forma e carga da proteína (Alfenas, 1998). As isoenzimas são controladas geneticamente por um ou vários genes, situados num mesmo loco ou em diferentes locos (Alfenas et al., 1991). A variação na intensidade de bandas de atividade enzimática que são visualizadas em gel, denominadas isoenzimas, é função da atividade enzimática, da estrutura quaternária da enzima, do número de loco e número de alelo no loco que contribuem para a síntese da enzima (Alfenas et al., 1991).

Esta técnica apresenta vantagens em relação aos outros métodos clássicos quantitativos de análise da estrutura genética de populações, pois: permite a análise de vários locos simultaneamente; os alelos de cada loco são codominantes, permitindo a identificação de heterozigotos; e mede a variabilidade a um nível próximo do DNA pois constituem um produto direto da ação gênica (Alfenas, 1991). Cheliak \& Pitel (1984), acrescenta que os marcadores genéticos não são associados às características fenotípicas observadas, sendo, portanto, neutros, ou seja, agem como variantes casuais não influenciadas diretamente pela ação natural, permitindo a formulação de hipóteses relativas à quantidade, distribuição e manutenção da variabilidade genética.

A principal limitação da técnica de isoenzimas é o número pequeno de locos acessíveis e a variação da expressão das isoenzimas de acordo com o tecido da planta (Pereira, 2002. A mesma afirma ser o grau de polimorfismo geralmente de baixo a moderado, enquanto que em outras técnicas, como microssátelites, é alto. 


\subsection{A espécie}

\section{Ocorrência}

A espécie Eschweilera ovata (Cambess.) Miers, conhecida popularmente por biriba ou imbiriba, pertencente à família Lecythidaceae, é uma espécie com distribuição disjunta entre o leste da Amazônia e o leste do Brasil. Característica e exclusiva das matas pluviais Atlântica e Amazônica, apresenta frequiência ocasional e dispersão quase que contínua ao longo da sua área de distribuição entre os Estados de Pernambuco e Espírito Santo (Mori, 1995; Lorenzi, 1998; Mainieri et al, 1989). Espécie perenifólia, heliófita, seletiva xerófita, ocorre preferencialmente em terrenos bem drenados, tanto na floresta primária como em formações abertas e capoeiras (Lorenzi, 1998; Mori, 1990).

\section{Descrição morfológica e fenologia}

Árvore de porte pequeno a médio, com altura de 3 a $20 \mathrm{~m}$, dotada de copa piramidal densa. Sendo que, nas restinga e capoeiras, costuma apresentar-se, florescendo e frutificando, como um arboreto com tamanho médio de $3 \mathrm{~m}$. Possui tronco ereto e cilíndrico, de 40 - $60 \mathrm{~cm}$ de diâmetro, revestido por casca grossa, acizentada, com fissuras longitudinais superficiais. A casca pode variar também de acordo com o ambiente no qual a espécie se desenvolve: nas capoeiras e áreas abertas apresenta-se mais clara e no interior das matas a casca é quase negra . Lâminas foliares elípticas, 5$14,5 \mathrm{~cm}$ x 3-6,5 cm, glabra, cartácea a coriácea, com oito a dez pares de nervuras laterais visíveis, ápice agudo ou acuminado, base obtusa a redonda, margens inteiras, pecíolo de 5 a $10 \mathrm{~cm}$ de comprimento. Plantas de mata higrófila possuem folhas maiores e menos espessas que as plantas de restinga e capoeira. (Mori \& Prance, 1983, 1990; Mori, 1995; Lorenzi, 1998).

Inflorescências em racemos ou terminais axilares, geralmente não ramificado, de 3-12 cm de comprimento. Flores amarelas e brancas, com tamanho de 3-4 cm de diâmetro, zigomorfas, cálice com 6 lóbulos bem ovalados, pétalas em número de seis, usualmente amarelo claro, às vezes branco, bem ovalados, com capuz estaminal completamente espiralado, formando um rolo duplo, apêndices do capuz completamente 
estéreis, anel estaminal com 160 - 170 estames, ovário bilocular, com 7-9 óvulos basalmente anexados, estilete com cerca de $2-3 \mathrm{~mm}$. Frutos turbinados, pixídios, deiscentes, geralmente assimétrico na base, 2,5-3,5 x 2,5-4,0 cm (excluindo o opérculo). Pericarpo 2-3 mm de espessura, contendo de 1 a 4 sementes listradas, com arilo lateral (Mori \& Perante, 1983, 1990; Mori, 1995; Lorenzi, 1998).

Flores podem ser encontradas durante todo o ano, com exceção de junho, julho e agosto, contudo, a floração parece estar concentrada nos meses compreendidos entre setembro e fevereiro. Costuma ocorrer quando as folhas estão maduras, não existindo uma relação entre o lançamento de folhas e a floração. A polinização das flores foi freqüentemente observada sendo realizada por abelhas do gênero Xylocopa (Mori \& Prance, 1981; Mori, 1988; Knudsen, 1996) Santos (2003), em recente estudo da polinização da espécie, aponta também Xylocopa frontalis como o principal polinizador na área de estudo, enquanto Epicharis bicolor, Eulaema nigrita e Eufriesea mussitans como sendo polinizadores secundários. A frutificação costuma ocorrer de janeiro a junho. Apesar da ausência de informações disponíveis para a espécie, estudos com outras plantas da família indicam que os frutos de Lecythidaceae costumam ser dispersos, principalmente, por morcegos, aves, pequenos roedores e símios (Prance \& Mori, 1978; Mori, 1990; Forget, 1992; Stevenson, 2001).

\section{Utilização}

A sua madeira é pesada e dura ao corte, compacta, uniforme, de propriedades mecânicas altas, mediamente resistente ao ataque de fungos e moderadamente durável, podendo ser usada para construções externas, como postes e mourões, dormentes, estacas marítimas e trapiches, entre outros serviços de marcenaria (Mainieri et al., 1989; Lorenzi, 1998). Porém o principal objetivo de sua exp loração é para se confeccionar o arco (verga) do berimbau. Estudos recentes têm demostrado que a madeira da biriba possui excelentes características de sonoridade, ressonância e operacionalidade, justificando, em parte, a empiricidade de seu uso como artefato deste mais típico instrumento musical da Bahia (Bonates et al., 1998). 
A espécie apresenta um grande potencial de rebrotamento quando seus caules são cortados. Seus indivíduos possuem uma porção caulinar subterrânea disposta horizontalmente, que se torna bastante engrossada com o desenvolvimento da planta. Os brotamentos se dão desse órgão subterrâneo, ou mesmo das porções aéreas remanescentes dos caules cortados (Assis \& Piccolo, 2000). A expressiva regeneração vegetativa da espécie favorece para que a mesma seja uma promissora fonte de matériaprima, seja para a construção de berimbaus ou para outras finalidades.

A espécie também é recomendada para composição de reflorestamento mistos destinado à recuperação da vegetação de áreas degradas (Lorenzi, 1998). Neste sentido, Montagnini et al.(1995) a considera uma espécie chave em processos de recuperação de áreas degradadas, contribuindo à reabilitação do solo através do incremento de carbono e nitrogênio. Em se tratando da restauração ecológica de paisagens degradadas, Reis \& Kageyama (Reis et al., 1999) atentam pela utilização de "bagueiras", que são espécies atrativas na alimentação de um grande número de animais para ampliar as probabilidades de dispersão de propágulos advindos de outras áreas. A E. ovata é uma espécie bastante atrativa neste sentido, já que por apresentar estas características, são utilizadas como "seva" por caçadores locais em sua época de frutificação.

Estudos fitoquímicos com outras espécies do gênero Eschweilera apresentaram alguns constituintes com atividades farmacológicas antifúngicas e antimicrobianas, pela presença de triterpenos pentacíclicos, saponinas, ácidos elágicos e alcalóides (Carvalho, 1999), havendo necessidade de estudos para averiguar a presença destes compostos em E. ovata.

\section{Dinâmica sucessional}

Em estudo comparativo da vegetação em três estágios de sucessão (capoeira baixa, < 2 anos; capoeira alta, > 20 anos; mata primária) na Estação Ecológica do Paut brasil, Bahia, realizado por Serpa et al. (1984), foi observado que E. ovata ocorreu nos três tipos de vegetações estudadas, tendo sido na capoeira alta a espécie com maior densidade. Neste mesmo trabalho, ao se comparar os índices de valor de importância 
(IVI) das espécies para cada estágio de sucessão, a espécie se apresentou em quinto lugar na capoeira alta e em terceiro lugar na mata primária.

Outros estudos conduzidos em Florestas de Tabuleiros do sul da Bahia e norte do Espírito Santo, verificaram que a espécie pode ocorrer em densidades consideravelmente elevadas (Rizzini et al., 1997; de Souza et al., 1996; Mori et al., 1983). Assis \& Piccolo (2000) estimaram densidades de 190 e 210 indivíduos/ha, desde plântulas a adultos, em duas diferentes áreas de ocorrência de biriba, tendo apresentado área basal de 1,05 e 2,21 $\mathrm{m}^{2} /$ ha, sendo o maior valor obtido em área menos antropizadas. Mori et al. (1983) estimaram $16 \mathrm{ind} / \mathrm{ha}$ da espécie com DAP $\geq 10 \mathrm{~cm}$ em estudo realizado no sul da Bahia. Souza et al. (1996), considerando DAP $\geq 10 \mathrm{~cm}$, obtiveram a estimativa de $39,1 \mathrm{ind} / \mathrm{ha}$ pem um fragmento também no sul da Bahia.

Prance (1975) verificou altos valores de densidade para 5 espécies dessa família (Lecythidaceae), sendo que estas cresciam principalmente por brotamentos. Prance \& More, (1979) alertam ao fato das espécies que possuem a habilidade de rebrota, podem tornar-se dominantes em vegetação secundária, sendo favorecidas pela ocorrência sucessiva desse tipo de ação perturbadora. Galvão \& Medeiros (2002) fazem menção à espécie, na ocupação em altas densidades destas em áreas de pastagem recém formadas, atribuindo o fato, a capacidade de rebrota desta.

Com relação ao grupo sucessional, no presente trabalho, a E. ovata será classificada como espécie climácica, atuando como pioneira antrópica na ocupação de áreas degradas. Esta classificação foi baseada nas seguintes características apresentadas pela espécie: apresenta velocidade de crescimento de média a lenta; possui madeira dura e pesada; demostra-se tolerante à sombra, com rebrota independente das condições local de luz; é pouco exigente a tipo de ambientes; suas sementes são dispersas por muitos animais (zoocórica) ou por gravidade (barocórica), não apresentando dormência, sendo estas sementes do tipo recalcitrantes, perdendo o poder germinativo muito rapidamente; possui polinizadores específicos; apresenta alta densidade de indivíduos na floresta, o que a caracteriza como uma espécie comum; apresenta tempo de vida longo. 


\subsection{O Manejo tradicional da biriba por populações locais}

A capoeira, uma manifestação cultural afro-brasileira, apresenta-se como um jogo/luta, traz embutido em seu universo outros elementos, como a dança e a música. Em torno de seu desenvolvimento, desde de seu princípio até atingir o estágio de complexidade em que ela se expressa hoje, muitos elementos influenciaram sua trajetória, mantendo vários traços marcantes da cultura negra. Conhecida e praticada em todo o Brasil e presente em mais de 50 países, é considerada como esporte pelo Comitê Olímpico Mundial. O jogo da capoeira chega aos nossos dias com um conteúdo artístico, filosófico, cultural, histórico e social resultado de uma intensa contribuição sócio cultural dos africanos e seus descendentes na formação de uma identidade nacional, englobando valiosos aspectos etnobiológico em seu contexto.

$\mathrm{O}$ berimbau, um instrumento musical utilizado como componente principal da orquestra da capoeira, onde tem a função de impor um comando rítmico ao jogo, constitui elemento indispensável à sua execução (Oliveira, 1958; Shaffer, 1977). A Eschweilera ovata, por ser culturalmente tradicional e ligado intrinsecamente aos valores que regem o ambiente da capoeiragem, é a espécie preferencialmente utilizada na confecção deste instrumento. Devido ao crescimento vultuoso da capoeira e na transformação do berimbau em um símbolo áudio-visual da Bahia e, por conseguinte, em um dos souvenires mais comercializados no estado (Menezes, 1996) - citado por Pacheco (2002), a exploração de E. ovata vem se intensificando nos últimos anos, envolvendo um número significativamente grande de pessoas envolvidas nas atividades relacionadas ao comercio do berimbau, que vai desde a extração da biriba até a comercialização do instrumento tanto no mercado interno como externo, com um valor agregado bastante alto.

A fragmentação, devido principalmente ao crescimento desorganizado da urbanização da grande Salvador, tem ocasionado uma lenta e gradual diminuição dos espaços tradicionalmente utilizados para coleta desse recurso, pondo em risco as das populações de Eschweilera ovata nestes locais, bem como da manutenção dos ricos aspectos sócio culturais que envolvem seu uso (Pacheco, 2002 - não publicado) 
Visto a urgente demanda de minimizar os problemas relacionados ao uso desordenado deste recurso florestal, estudos visando conhecer os aspectos da extração e uso de E. ovata foram realizados através de uma equipe multidisciplinar e apresentado por Cunha et al. (1996), dimensionando e mapeando o processo extrativo em Fragmentos de Mata Atlântica e englobando as relações sócio-econômicas existentes na extração desta espécie. Conjuntamente, realizoutse a evolução espaço-temporal da cobertura vegetal. Estes estudos geraram alguns sub-produtos os quais foram apresentados por Assis \& Piccolo (2000), enfocando principalmente os padrões estruturais de populações impactadas, e por Neves et al. (1999), divulgando este trabalho no primeiro Seminário Nacional sobre Recurso florestais da Mata Atlântica, cujo tema foi a exploração e utilização dos recursos, seus impactos sócio-econômicos atuais e potencialidades de manejo sustentável.

Algumas considerações, com relação ao estudo a respeito do manejo da espécie E. ovata, apresentadas pelos autores acima citados, serão aqui explicitadas como forma de auxiliarem nas implicações a respeito do manejo da espécie.

1) O conhecimento do eixo etnobotânico deste estudo demostrou que após o corte em qualquer lugar do caule, ela rebrota com dois a cinco perfilhos, sendo possível observar moitas com mais de uma dezena destes perfilhos.

2) a prática de extração não diminui a densidade de caules de biriba na mata, ao contrário, esta induz um aumento no número destes devido a capacidade de rebrota.

3) As populações de E. ovata das áreas analisadas demostraram-se sofrer exaustivas intervenções, apresentando poucos indivíduos adultos na área mais antropizada abordada pelo estudo. Nestas áreas, não foram observadas qualquer planta jovem isolada, pois todas pertenciam a sistemas de rebrotas das moitas sendo este fato atribuindo ao pequeno número de indivíduos adultos na área, decorrente de ações antrópicas no passado, podendo ser o fator de impedimento à reprodução sexuada.

4) Há necessidade de manter indivíduos adultos na população, para a manutenção da reprodução sexuada, garantindo a diversidade genética. 
5) A espécie apresenta distribuição diamétrica do tipo "J" invertido, porém a extração exaustiva do recurso em uma área pode levar ao desbalanceamento desta curva, pondo em risco o recrutamento de indivíduos jovens para a classe dos adultos.

6) Existe há necessidade de estabelecimento de plano de rot ação dentro da mata estudada, que, segundo informação dos extratores, este está em torno de um ano, sendo este período questionado pelos autores. Porém, dentro do tempo do projeto, dados sobre esta questão não foi possível de serem obtidos.

Mesmo não sendo o trabalho acima mencionado, realizado nas mesmas áreas utilizadas para a coleta de dados do presente estudo, este conhecimento vem a ser útil quando da inferência sob a estrutura demográfica populacional de E. ovata submetidas à exploração. 


\section{MATERIAIS E MÉTODOS}

\section{1 Áreas de estudo}

Para a escolha das áreas de estudo, realizourse o levantamento de informações, junto a pessoas que possuíam conhecimento das atividades de coletores, artesãos e comerciantes de berimbaus na Grande Salvador, a respeito de áreas com ocorrência de populações de biribas que apresentassem diferentes graus de interferência antrópica.

Efetuourse o reconhecimento de locais de extração de biribas através de visitas às áreas, acompanhadas pelos extratores que as utilizavam para coleta de material, sendo selecionada para o estudo como representante de uma área de extração, a que possuía um maior número de informações do histórico de interferência antrópica, e que não incluísse outro tipo de interferência alheia à exploração de caules da espécie para a confecção do berimbau, bem como apresentava condição logística viável para implantação da atividade desta pesquisa. Criteriosa também foi a escolha de outras duas áreas para amostragem de populações de E.ovata que não sofressem atividade de exploração.

Deve-se ressaltar que as matas nesta região são, ainda hoje, fontes fornecedoras de matéria-prima para moradores locais. Além da extração de biribas, outra atividade comumente realizada é a extração de fibras de piaçava, considerada, aparentemente, como atividade de baixo impacto. Nessas, soma-se ainda uma notória exploração de produtos madeireiros, realizada de forma predatória, sem distinção de técnicas que garantam um sistema de manejo sustentável, destinado, principalmente, à construção civil. Firmou-se a 
amostragem para o estudo genético da espécie em três populações naturais de E. ovata, sendo elas:

- Mata de Itaparica 1 (ITE) - população natural sob regime de exploração tradicional. Esta área localiza-se no Município de Itaparica - BA, nas proximidades da localidade denominada de Tairu. A área está contida em um contínuo florestal bastante extenso, formado por um mosaico de estruturas fisionômicas distintas determinadas em função das diferentes interferências antrópica sofridas ou ainda atuantes, apresentando desde capoeirões em processo de regeneração, bem como áreas com fisionomias da Floresta Ombrófila Densa secundária. Esta floresta vem, a mais de uma década, sendo utilizada intensamente para a extração de caules da espécie E.ovata destinados à fabricação de berimbau.

- Mata de Itaparica 2 (ITBA) - população natural sob baixa influência antrópica. Localiza-se próxima à população sob regime de exploração de Itaparica, porém, devido a não autorização do proprietário, dificuldade de acesso de pessoal e escoamento da matéria-prima do local, esta não é utilizada pelos extratores, apresentando fisionomia da Floresta Ombrófila Densa em bom estado de conservação.

- Mata de Camarugipe (CAN) - população natural sob baixa influência antrópica. Localiza-se no município de Malhada - BA, próxima à Reserva de Sapiranga, sendo a área administrada pela Fundação Garcia D`Ávila,. Considerada pelos pesquisadores locais como sendo uma das florestas que menos sofreu a ação do homem na região norte de Salvador, tem cerca de 1.300 ha de floresta contínua. Segundo informações de moradores locais, as atividades de extração seletiva de madeira podem ter ocorrido no local, não havendo, porém, nenhum indício de que possíveis atividades perturbadoras de grande impacto deste ambiente possam ter ocorrido nos últimos 30 anos.

Um esquema representativo da localização das áreas pode ser visto na Figura 1. 

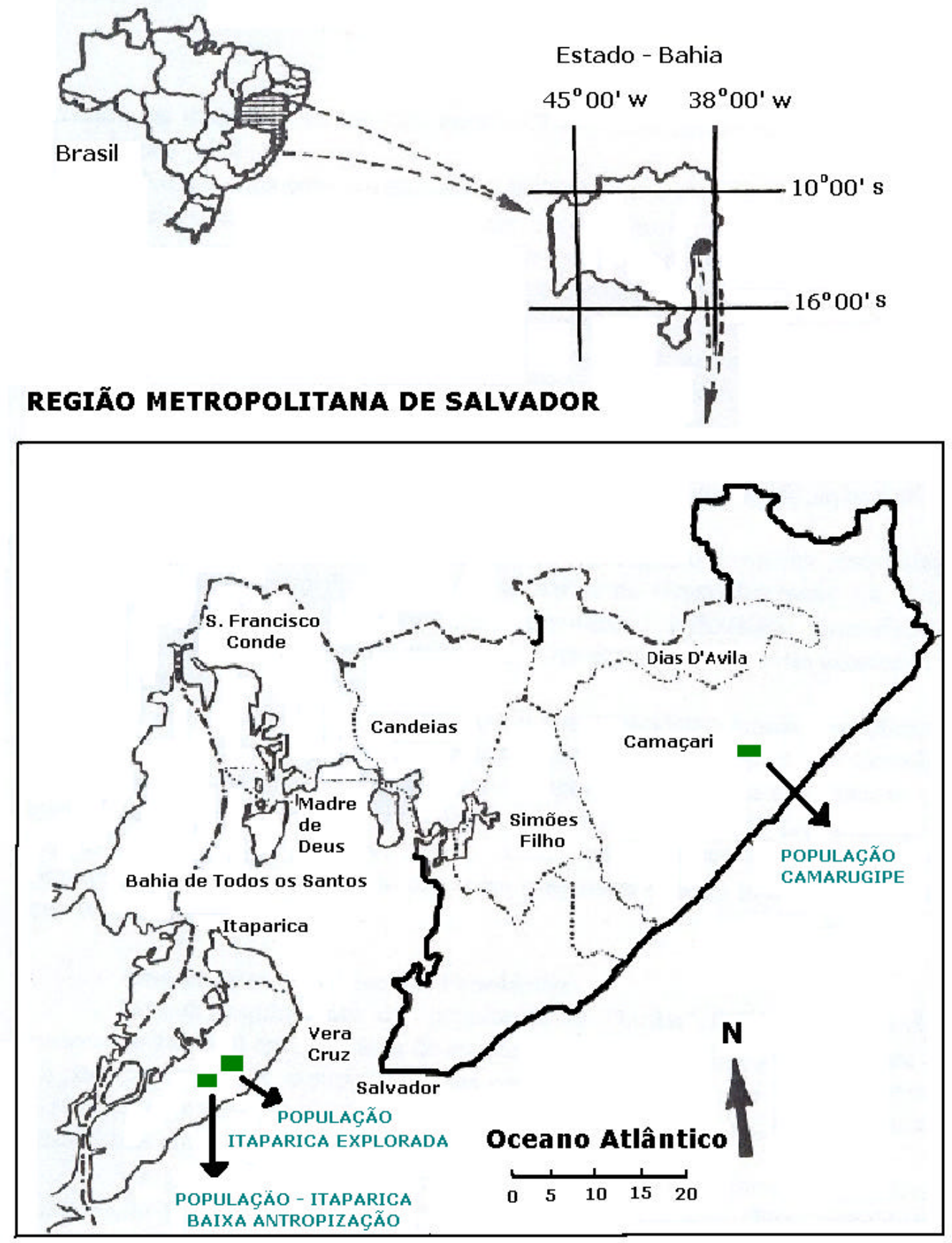

Figura 1 - Mapa esquemático da localização das áreas de estudo (adaptado de Assis \& Picollo, 2000) 
A distância da Mata de Camarugipe com relação às áreas localizadas em Itaparica é de 95,1 Km (ITE) e 96,7 Km ( ITBA), sendo a distância entre estas duas áreas de Itaparica de aproximadamente $1.830 \mathrm{~m}$. As coordenadas geográficas aproximadas das áreas são: $13^{\circ} 01^{\prime}$ 90" S e $38^{\circ} 43^{\prime} 97^{\prime \prime} \mathrm{W}$ para a população ITE; $13^{\circ} 02^{\prime} 63^{\prime \prime} \mathrm{S}$ e $38^{\circ} 44^{\prime} 70$ " W para a população de ITBA; e $12^{\circ} 30^{\prime} 43^{\prime \prime}$ S e $38^{\circ} 01^{\prime} 87$ W " para a população de Camarugipe. As três áreas se caracterizam por apresentarem uma vegetação característica da Floresta Ombrófila Densa de tabuleiros de planícies litorâneas. Essas apresentam uma estratificação evidente com cerca de 15 a 20 metros de altura, salvo algumas emergentes, sendo esta altura um pouco menor na área de exploração, com cerca de 10 a 15 m. As áreas apresentam-se em condições secundárias com diferentes grau de conservação, conforme apresentado anteriormente.

O clima regional é do tipo tropical constantemente úmido, classificado como $\mathrm{AF}$ no sistema Köppen. As temperaturas médias anuais são elevadas ( $24^{\circ} \mathrm{C}$ ), sem ocorrência de estação fria. Mesmo nos meses quentes, as temperaturas médias sempre são superiores à $15^{\circ}$ C. Os totais pluviométricos variam entre 1750 a $2000 \mathrm{~mm}$ anuais, sendo relativamente bem distribuídos durante as diferentes estações do ano, com uma curta estação seca nos meses de janeiro e fevereiro.

\subsubsection{Caracterização da extração e come rcialização de "biribas" em Itaparica.}

A grande riqueza de elementos etnobotânicos que envolvem esta atividade e o significativo contingente de pessoas envolvidas na cadeia de comercialização, bem como a forma que esta ocorre, fazem com que a apresentação destas informações, baseadas em dados empíricos advindos dos exaustivos diálogos realizados junto aos extratores e comerciante local, no período de coleta de dados para este trabalho, ainda que sucinta, seja importante para a compreensão da atividade de extração da espécie neste local. Contribuindo, assim, não apenas para o entendimento dos resultados deste trabalho, mas principalmente para a proposição de um manejo adequado da espécie em áreas naturais. 
A extração de "biribas" para a confecção desse instrumento se da através do corte de caules de indivíduos jovens da espécie. São caules úteis para esta finalidade os que apresentam cerca de 3 a $5 \mathrm{~cm}$ de diâmetro, desprovidos de nós e retilíneos. O corte é usualmente feito na base do caule a uma altura variável, de 10 a 30 centímetros. Porém, muitas vezes podem ser observados indivíduos cortados a alturas superiores, bem como o corte de indivíduos de maior diâmetro. Este tipo de corte é realizado para se obter partes de caule úteis que se encontram em alturas superiores. Devido à alta capacidade de rebrota da espécie, verifica-se que após o corte dos caules, estes emitem brotações laterais na cepa, sendo o número de brotos variável. Assis \& Picollo (2000), em outras áreas de extração de caules da espécie para esta finalidade, observaram que esta atividade de corte favorece o aumento do número de caules da espécie na área para a extração futura, devido ao sucesso no fenômeno de rebrota. A verga (arco do berimbau) possui não mais que dois metros, assim, toda a prrção de caule do indivíduo cortado que apresente estas condições são utilizadas, podendo um único caule proporcionar mais que uma verga.

No contínuo florestal onde se realizou o estudo, cerca de quatro extratores atuam freqüentemente, tendo esta atividade como a principal fonte de renda. Este número de pessoas pode aumentar dependendo da demanda do mercado. Esta demanda é maior nos meses de dezembro a fevereiro, em consequiência principalmente do aumento do turismo na região de Salvador. O número de "biribas" (ou caules de E.ovata) extraídas pela equipe varia de 100 a 150 unidades por dia. O tempo de retorno a uma área já explorada, segundo informações dos extratores, está em torno de um ano. Deve-se ressaltar que este tempo não é, possivelmente, o mesmo que um rebroto necessita para atingir a classe de diâmetro considerada viável para o corte. Este é, porém, o tempo necessário para que a área apresente novos caules, recrutados em função do crescimento de novas plantas via sementes na área, ou do desenvolvimento de brotações de cepas geradas em cortes anteriores à intervenção de um ano. 
O transporte dessa matéria-prima é realizado por animal, assim é mais comum a extração nas proximidades (cerca de $200 \mathrm{~m}$ ) das trilhas utilizadas por estes extratores para se movimentarem na floresta. Esse material é repassado a um comerciante local que revende em diversos mercados, tendo como principal ponto de venda o Mercado Modelo, ponto de artesões em Salvador. No caso local, os extratores são ressarcidos financeiramente em função do cento de vergas úteis entregues ao comerciante. As vergas que não servem para a confecção do instrumento, são reaproveitadas na construção de estruturas rústicas, como cercas, casas, entre outras. Segundo informações destas pessoas, o aproveitamento da coleta de biribas par confecção do instrumento é entorno de 70\%. A agregação de valor na cadeia de comercialização desse material, que se inicia na venda da matéria-prima pelo extrator até atingir o consumidor final, é bastante alta e desproporcionalmente distribuída.

\subsection{Amostragem}

Após prévio reconhecimento de trechos das florestas em estudo, visando uma caracterização preliminar de suas fisionomias para coleta de material foliar dos indivíduos nessas populações, foram determinadas áreas onde houvesse uma boa representatividade de indivíduos adultos da espécie. Nas populações de Camarugipe e Itaparica Explorada, fez-se um transecto, a partir do qual todos os indivíduos adultos que estivessem a até $20 \mathrm{~m}$ perpendicularmente a esse, foram numerados, recebendo identificação de seu respectivo número. A distância do transcecto variou em função do sucesso de identificação do número de árvores previamente estabelecido, o qual foi de 60 indivíduos. Na população de Itaparica de Baixa Antropização, ao invés da demarcação com transecto determinourse o posicionamento dos indivíduos através da obtenção da distância (Rumo) da última árvore marcada e angulação entre estas (azimute).

O georeferenciamento espacial de alguns indivíduos foi realizado com o auxílio de um aparelho de GPS, sendo possível na análise dos dados, a amarração dos pontos de localização de todos os indivíduos. Destes, anotou-se o DAP, a altura total e a localização 
espacial. Consideraram-se adultas as árvores que apresentavam DAP de aproximadamente 10 $\mathrm{cm}(\mathrm{CAP} \geq 30 \mathrm{~cm})$. A distribuição por casses de diâmetro do tronco dos indivíduos demarcados são apresentados na Figura 2. Estas populações apresentaram demografia muito semelhante, sendo de 52 e 56 árvores/ha na população de Camarugipe e na de Itaparica explorada, respectivamente.

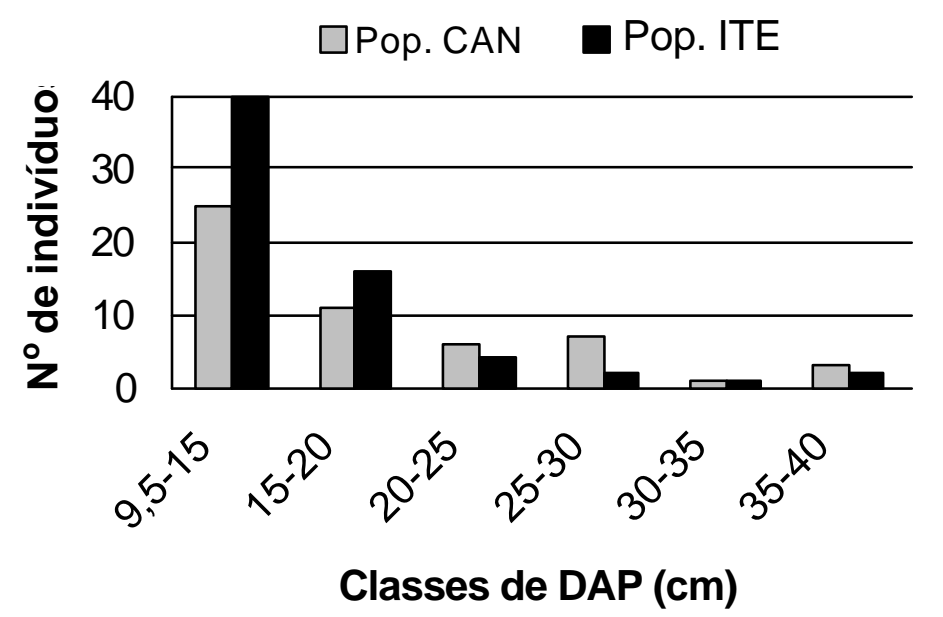

Figura 2 - Distribuição por classes diamêtricas dos troncos dos indivíduos amostrados nas populações natural e manejada

Para análise das populações foram amostrados tecidos foliares em 60 indivíduos adultos de cada população, totalizando 180 amostras. As amostras de tecidos foliares foram embaladas em sacos de papel identificados com o número da árvore de origem, acondicionados em ambiente refrigerado, por no máximo cinco dias, e transportadas ao Laboratório de Reprodução e Genética de Espécies Arbóreas (LARGEA - ESALQ/USP), onde foi realizado o processo de extração das isoenzimas. Estas amostras foram armazenadas em microtubo no ultrafreezer $\left(-80^{\circ} \mathrm{C}\right)$ onde aguardaram para serem utilizadas por um período máximo de três meses. 
Para a caracterização do sistema de reprodução, coletou-se semente de 30 árvores adulta na população explorada de Itaparica e na população de Camarugipe. Para a coleta caminhou-se aleatoriamente pelas florestas escolhendo as árvores que serviriam para esta finalidade em função da disponibilidade de sementes nas copas. Assim, a área utilizada para a coleta das sementes foi muito além da área de amostragem dos adultos, pelo fato de poucas árvores adultas demarcadas apresentarem número suficientes de sementes e que estivessem ainda nos frutos na copa. De cada árvore foram coletadas sementes em várias partes da copa, objetivando a obtenção de pelo menos 30 sementes viáveis por árvore matriz. As sementes foram colocadas para germinar em recipientes gerbox com vermiculita, separadamente por árvore matriz. A germinação foi realizada em incubadora, sob condições controladas de luz e temperatura. Estas condições consistiram em fotoperíodo de 8 horas com temperatura de $30^{\circ}$ $\mathrm{C}$, simulando o período de luz, e de $25^{\circ} \mathrm{C}$, durante o período escuro (16 horas).

Os gerboxes que apresentavam mais que 10 plântulas germinadas eram retirados da incubadora e colocados em ambiente natural, para continuidade do processo de desenvolvimento das mudas. O maior número de sementes germina das foi observado entre 20 e 25 dias após incubação De cada população foram analisadas por eletroforese de isoenzimas, plântulas de 20 árvores matrizes, e de cada árvore matriz foram genotipadas 10 plântulas, totalizando 400 plântulas analisadas (20 progênies x 2 populações x 10 plântulas).

\section{3 Protocolo de isoenzimas}

O protocolo de análise eletroforética de isoenzimas foi desenvolvido para E. ovata por não haver previamente nenhum estudo neste sentido. As "corridas" eletroforéticas foram realizadas no LARGEA (ESALQ/USP). Durante a extração das isoenzimas, testou-se o uso de três diferentes tampões, sendo determinado a utilização do tampão 1, citado em Alfenas (1998), por apresentar melhores resultados, além de ser bastante completo e já ser utilizado para várias espécies florestais. Após extração, wicks (papel whatman n.3) foram embebidos 
nos extratos obtidos, colocados em micro tubos e armazenados em um freezer $\left(-80^{0} \mathrm{C}\right)$, onde aguardaram o momento da realização da corrida eletroforética.

A constituição do gel foi adequada às condições de laboratório, sendo testado quatro sistemas tampão gel/eletrodo e 28 sistemas enzimáticos, apresentados no Quadro 1. A eletroforese de isoenzimas foi a horizontal, conduzida em meio suporte de gel horizontal de amido de milho (penetrose) e amido de batata (13\% de amido). Em cada gel foram colocadas 20 amostras e 3 wicks com azul de bromofenol para marcar distância de migração.

Os sistemas tampão gel/eletrodo e sistemas enzimáticos foram avaliados de acordo com a qualidade dos padrões de bandas obtidos nas amostras, nas diferentes condições de corrida. As bandas foram avaliadas quanto à atividade enzimática e quanto à resolução das mesmas (recebendo nota 0,1 ou 2). A constituição dos tampões e das soluções de revelação das diferentes enzimas foi usada de acordo com ALFENAS et al. (1991;1998). Para o material coletado dos indivíduos adultos, os sistemas tampões gel/eletrodo 8 - morpholinacitrato, $\mathrm{pH} 7,1 / 6,1$ e o sistema 25 - histidina-HCl/tris-citrato, $\mathrm{pH} 7,0 / 7,0$ foram os que apresentaram melhor resolução das bandas. Descartou-se a utilização dos sistemas 19 - triscitrato/sodio-borato, $\mathrm{pH}$ 7,5/7,5 e do TC- tris-citrato, $\mathrm{pH}$ 7,5/8,6, logo na primeira corrida eletroforética por não apresentarem boas resoluções para os sistemas enzimáticos que haviam apresentado atividade e melhor resolução nos outros sistemas tampões. 


\begin{tabular}{|c|c|}
\hline Enzima & Código \\
\hline Esterase & $\alpha$ EST - EC. 3.1.1.1 \\
\hline Malato Desidrogenase & MDH - EC 1.1.1.37 \\
\hline$\beta$ - Glucosidade & $\beta-$ GLU - EC 3.2.1.21 \\
\hline Fumarase & FUM - EC 4.2.1.2 \\
\hline Galactose desidrogenase & GLDH - EC 1.1.1.48 \\
\hline 6-fosfogluconato desidrogenase & 6PGDH - EC 1.1.1.44 \\
\hline Leucina aminopeptidase & LAP - EC 3.4.11.1 \\
\hline Menadinona redutase & MR -EC 1.6.99.3 \\
\hline Fosfatase ácida & $\mathrm{ACP}-\mathrm{EC} 3.1 .3 .2$ \\
\hline Glutamato desidrogenase & GDH - EC 1.4.1.3 \\
\hline Isocitrato desidrogenase & IDH - EC 1.1.1.42 \\
\hline Fosfoglucose isomerase & PGI -EC 5.3.1.9 \\
\hline Lactato desidrogenase & LDH - EC 1.1.1.27 \\
\hline Glucose-6-fosfato desidrogenase & G6PDH - EC 1.1.1.44 \\
\hline Álcool desidrogenase & ADH - EC 1.1.1.1 \\
\hline Nicotinamida adenina dinucleotídeo desidrogenase & NADHDH - EC 1.6.99.3 \\
\hline Glutamato-oxaloacetato transamitase & GOT - EC 2.6.1.1 \\
\hline Diaforase & DIA - EC 1.6.4.3 \\
\hline Peroxidase & PO - EC 1.11.1.7 \\
\hline Fosfoglucomutase & PGM -EC 2.7.5.1 \\
\hline Xiquimato desidrogenase & SKDH - EC 1.1.1.25 \\
\hline Sorbitol desidrogenase & SDH - EC 1.1.1.14 \\
\hline Fosfatase alcalina & ALP - EC 3.3.3.1 \\
\hline Superóxido dismutase & SOD - EC 1.15.1.1 \\
\hline Glicerato 2 desidrogenase & G2DH-EC 1.1.1.29 \\
\hline Endopeptidase & ENP- EC 3. 2. \\
\hline Manitol desidrogenase & MADH- EC 1.1.1.67 \\
\hline Peroxidase método II & POII- EC 1.11.1.7 \\
\hline
\end{tabular}

Quadro 1 - Enzimas testadas e seus respectivos códigos (Alfenas, 1998) 


\subsection{Análise estatística}

\subsubsection{Sistema de reprodução}

O sistema de reprodução da população de E. ovata foi analisado com base nos modelos de reprodução mistos de Ritland \& Jain (1981) e cruzamentos correlacionados (Ritland, 1989), com o auxílio do programa "Multilocos MLTR” (Ritland 1997). Foram estimadas: 1) a taxa populacional de cruzamento multilocos $\left(\hat{t}_{m}\right)$, pelo método de máxima verossimilhança (Expectation-Maximization - EM); 2) a taxa populacional de cruzamento unilocos $\left.\left(\hat{t}_{s}\right) ; 3\right)$ a taxa de cruzamento entre aparentados $\left.\left(\hat{t}_{m}-\hat{t_{s}}\right) ; 4\right)$ a taxa individual de cruzamento multilocos $(\hat{t}), 5)$ as freqüências alélicas dos óvulos e do pólen $(o$ e $p) ; 6)$ o índice de fixação nas árvores maternas $\left.\left(\hat{F}_{m}\right) ; 7\right)$ a correlação de autofecundação $\left(\hat{r}_{s}\right)$ e; 8$)$ a correlação de paternidade $\left(\hat{r}_{p}\right)$. As pressuposições do modelo misto são: a) que o conjunto de pólen é homogêneo para o cruzamento de todos os genótipos maternos; b) que os alelos de diferentes locos segregam independentemente e; c) que os locos avaliados não sofreram seleção ou mutação entre o evento reprodutivo e a análise dos indivíduos (Ritland \& Jain, 1981; Ritland, 1990).

O erro padrão das estimativas dos parâmetros foi obtido por 500 reamostragens bootstraps, onde a unidade de amostragem para as estimativas das taxas de cruzamento individual e populacional foi as plantas dentro das progênies e as progênies, respectivamente.

O teste de cruzamentos aleatórios foi avaliado pelo teste de Equilíbrio de HardyWeinberg, teste de homogeneidade entre as frequiências alélicas dos óvulos vs. pólen, calculando-se o estimador $\hat{F}_{S T}$ (Nei, 1977) apenas como uma medida de divergência genética entre frequiências alélicas de diferentes grupos. Para testar a significância de $\hat{F}_{S T}$, para cada loco, aplicou-se o teste de qui-quadrado $\left[\chi^{2}=2 n \hat{F}_{S T}(k-1) ; \mathrm{GL}=(k-1)(s-1)\right]$, proposto por Workman \& Niswander (1970), em que: $n$ = número de indivíduos nos dois grupos, $k=$ número de alelos e $s=$ número de grupos. Os índices de fixação para adultos $(\hat{F})$ e progênies $\left(\hat{F}_{p}\right)$ e seus respectivos intervalos de confiança foram obtidos por 10.000 
reamostragens bootstraps, estimativas estas obtidas pelo programa GDA (Lewis \& Zaykin 1999).

O coeficiente de coancestria $(\theta)$ dentro de progênies foi estimado do coeficiente de correlação de parentesco $\left(\hat{r}_{x y}\right)$, entre plantas dentro de progênies, conforme Ritland (1989),

$$
\hat{r}_{x y}=0,25\left(1+\hat{F}_{p}\right)\left[4 \hat{s}+\left(\hat{t}^{2}+\hat{s} \hat{t} \hat{r}_{s}\right)\left(1+\hat{r}_{p}\right)\right] .
$$

sendo, $\hat{F}_{p}$ o coeficiente de endogamia da geração parental e $\hat{s}$ é taxa de autofecundação (1$\left.\hat{t}_{m}\right)$. Os demais parâmetros foram definidos anteriormente. Como em espécies diplóides, na ausência de endogamia, o coeficiente de parentesco $\left(\hat{r}_{x y}\right)$ é o dobro do coeficiente de coancestria $(\boldsymbol{\theta})$, têm-se que:

$$
\begin{aligned}
& \hat{\theta}=\hat{r}_{x y} / 2 ; \mathrm{e}, \\
& \hat{\boldsymbol{\theta}}_{x y}=0,125\left(1+\hat{F}_{p}\right)\left[4 \hat{s}+\left(\hat{t}^{2}+\hat{s} \hat{t} \hat{r}_{s}\right)\left(1+\hat{r}_{p}\right)\right] .
\end{aligned}
$$

O tamanho efetivo de variância de uma simples progênie foi estimado com base em Cockerham (1969),

$$
\hat{N}_{e(v)}=\frac{0,5}{\hat{\theta}\left(\frac{n-1}{n}\right)+\frac{1+\hat{F}_{o}}{2 n}}
$$

\subsubsection{Diversidade genética intrapopulacional}

A diversidade genética intrapopulacional foi avaliada pelas freqüências alélicas, heterozigosidade observada $\left(\hat{H}_{o}\right)$, diversidade gênica esperada segundo o equilíbrio de Hardy-Weinberg $\left(\hat{H}_{e}\right)$, número médio de alelos por loco $(A)$, porcentagem de locos polimórficos $(P)$ e índices de fixação de Wright $(\hat{f})$ - estimativas obtidas a partir do programa BIOSYS-1 (Swofford \& Selander, 1989). As freqüências alélicas foram estimadas por $: \hat{p}_{i j}=n_{i j} / n_{\cdot j}$, em que $\hat{p}_{i j}=$ freqüência do alelo $i$ na população $j ; n_{i j}=$ número de ocorrência do alelo $i$ na população $j ; n_{\cdot j}=$ número total de alelos amostrados na população $j$. 
A $\hat{H}_{o}$ para cada loco foi obtida por $H_{o}=1-\Sigma P_{i i}$, em que: $P_{i i}=$ frequiência do homozigoto $i i$ e $\hat{H}_{e}$ por $\hat{H}_{e}=1-\sum p_{i}{ }^{2}$, em que: $p_{i}=$ frequiência alélica estimada do $i$-ésimo alelo. $\mathrm{O}$ valor de $P$ foi estimado pela média arlTEética do número total de locos polimórficos dividido pelo número total de locos (polimórficos + monomórficos). O índice de fixação $(\hat{f})$ foi estimado por:

$$
\hat{f}=1-\frac{\hat{H}_{o}}{\hat{H}_{e}}
$$

A representatividade genética dos indivíduos adultos das populações, foi realizada pelo tamanho efetivo de endogamia ( $\hat{N}_{e}$ ), de acordo com Vencovsky (1997),

$$
\hat{N}_{e}=\frac{n}{1+\hat{f}}
$$

em que $n$ é o tamanho amostral e $\hat{f}$ é o índice de fixação de Wright.

\subsubsection{Estrutura genética}

A distribuição da variabilidade genética entre e dentro das populações foi caracterizada pelas estatísticas $F$ de Wright, segundo a metodologia de Cockerham \& Weir (1984), utilizando o programa GDA (Lewis \& Zaykin (1999).

\section{Análise de variância de freqüências alélicas}

Em um primeiro momento analisaram-se os dados considerando duas populações e, após, desconsiderando-se esta estrutura, tomando os dados como sendo de uma única população.

Esta análise foi inicialmente realizada ao nível de alelo e, posteriormente, conjunta para todos os alelos. Para cada alelo de cada loco polimórfico das plantas adultas e plântulas foi feita a análise de variância no modelo aleatório hierárquico desbalanceado, baseado em Weir (1990) e Vencovsky (1992). Assim, de acordo com estes autores, a 
variável Xil corresponde ao gene "l” na população “i”, portanto, quando xil estava presente recebeu o valor um, e quando estava ausente recebeu o valor zero.

\subsubsection{Estrutura nas populações de árvores adultas}

Para análise das frequiências alélicas das árvores adultas foi realizada pelo modelo estatístico,

$$
\mathrm{Y}_{\mathrm{ikl}}=\mathrm{m}+\mathrm{p}_{\mathrm{i}}+\mathrm{b}_{\mathrm{k}(\mathrm{i})}+\mathrm{g}_{(\mathrm{ik})}
$$

em que, $Y_{\text {ikl }}$ : frequiência do gene 1, dentro do indivíduo k, dentro da população i; m: média geral da frequiência alélica; $p_{i}$ : efeito da população i, com i $=1,2, \ldots, a$; $b_{k(i)}$ : efeito do indivíduo $\mathrm{k}$, dentro da população $\mathrm{i}$, com $\mathrm{k}=1,2, \ldots, \mathrm{b}_{\mathrm{i}}$; $\mathrm{g}_{(\mathrm{ik})}$ : efeito do gene 1 , dentro do indivíduo $\mathrm{k}$, dentro da população i, com $1=1,2, \ldots, n_{\text {ik. }}$

Os parâmetro estimados foram: divergência genética média entre populações, $\hat{\boldsymbol{\theta}}_{P}$; correlação entre alelos dentro de indivíduos de diferentes populações, $\hat{F}$; correlação entre alelos dentro de indivíduos de mesma populações, $\hat{f}$.

\subsubsection{Análise Individual das Populações}

O modelo estatístico para a análise hierárquica de indivíduos dentro de progênies foi:

$$
Y_{i j k}=m+f_{i}+b_{j(i)}+g_{k(i j)}
$$

em que, $Y_{i j k}=$ frequiência do alelo $k$, dentro do indivíduo $j$, dentro da progênie $i ; m=$ média geral das freqüências alélicas; $f_{i}=$ efeito da progênie $i$, com $i=1,2, \ldots, a ; b_{j(i)}=$ efeito do indivíduo $j$, dentro da progênie $i$, com $j=1,2, \ldots, b_{i} ; g_{k(i j)}=$ efeito do alelo $k$, dentro do indivíduo $j$, dentro da progênie $i, \operatorname{com} k=1,2, \ldots, n_{i j}$.

Estimou-se o coeficiente de coancestralidade médio entre duas plantas dentro das progênies $\left(\hat{\boldsymbol{\theta}}_{F}\right)$ ou divergência genética entre progênies; a correlação entre alelos, dentro de indivíduos de diferentes progênies, $\hat{F}$; e o índice de fixação ou correlação entre alelos dentro de indivíduos de uma mesma progênie, $\hat{f}$. 


\subsubsection{Análise da variância conjunta das populações}

Para análise da variância das frequiências alélicas de indivíduos dentro de progênies, dentro de populações, utilizoutse o modelo estatístico:

$$
Y_{i j k l}=m+p_{l}+f_{i(l)}+b_{j(i l)}+g_{k(i j l)}
$$

em que, $Y_{i j k l}=$ frequiência do alelo dentro do indivíduo, dentro da progênie, dentro da população ; $m=$ média geral das frequiências alélicas; $p_{l}=$ efeito da população $l, \operatorname{com} i=1,2$, $\ldots, a ; f_{i(l)}=$ efeito da progênie $i$, dentro da população $l$, com $i=1,2, \ldots, b_{l} ; b_{j(i l)}=$ efeito do indivíduo $j$, dentro da progênie $i$, dentro da população $l, \operatorname{com} j=1,2, \ldots, c_{i l} ; g_{k(i j l)}=$ efeito do alelo $k$, dentro do indivíduo $j$, dentro da progênie $i$, dentro da população $l$, com $k=1,2, \ldots$, $n_{i j l}$.

Para verificar se as estimativas médias de $\hat{\boldsymbol{\theta}}_{P}, \hat{\boldsymbol{\theta}}_{F}, \hat{F}, \mathrm{e} \hat{f}$ eram diferentes de zero, estimaram-se os intervalos de confiança a $95 \%$ de probabilidade pelo método de reamostragem bootstraps. Foram utilizadas 10.000 repetições sobre os locos.

\subsubsection{Distribuição espacial de genótipos}

A análise de autocorrelação genética espacial foi realizada dentro de duas das populações. Para análise de autocorrelação espacial, os dados de cada genótipo foram codificados para suas freqüências alélicas, ou seja, quando o genótipo era homozigoto para o alelo sob análise recebeu valor 1,0, quando heterozigoto recebeu valor 0,5 e quando homozigoto para outro alelo recebeu valos 0,0 (Sokal e Oden, 1978). Para locos que tinham mais de dois alelos, a análise foi realizada para todos os alelos, independente de sua freqüência. Todos os possíveis pares de combinações de árvores foram considerados como um conjunto e foram acessados para uma das 10 classes de distância. As extensões das classes de distância foram selecionadas sem a equalização do número total de cada conjunto de pares de comparações, sendo as classes de distância eqüidistantes dentro da população 
analisada Foram calculados os valores do índice $I$ de Moran (Sokal e Oden, 1978) para cada uma das classes de distância, em cada loco e para a média dos locos pela expressão:

$$
\hat{I}=n \sum_{i} \sum_{j} w_{i j} Z_{i} Z_{j} / w \sum_{i} Z_{i}^{2}
$$

em que: $w_{i j}=1$ para todas as células $i$ e $j$ localizadas em uma classe de distância $(r, r+\Delta r)$, e do contrário $w_{i j}=0$; Wé a soma de todos os pesos (contagem de todos os pares usados em todos os casos); e $Z_{i}$ é o desvio da frequiência alélica da $i$-ésima célula da média. $\mathrm{O}$ valor esperado de $\mathrm{I}=-1 /(n-1)$ aproxima-se de zero para grandes $n$. Os valores estimados do índice I de Moran foram usados para testar a significância dos desvios dos valores esperados, $\mathrm{E}(I)=$ -1/(n-1), sobre a hipótese de nulidade de distribuição aleatória (Cliff e Ord, 1981). A significância total de cada correlograma foi testada usando critérios de Bonferroni (Sakai e Oden, 1983). As análises de autocorrelação espacial e os teste foram realizado utilizando-se o programa SAAP (versão 4.3) de D. Wartenberg. 


\section{RESULTADOS E DISCUSSÃO}

\subsection{Sistemas enzimáticos}

Dos 28 sistemas enzimáticos testados no protocolo de isoenzimas dos indivíduos adultos de E.ovata, 13 apresentaram atividade. Destes, quatro ( $\alpha$-EST, PGM, GOT e G6PDH) apresentaram baixa resolução ou revelação irregular, motivo pelo qual foram descartados. Os nove sistemas selecionados para serem utilizados apresentaram condições passíveis de interpretação das bandas. Considerou-se trabalhar com o sistema tampão gel/eletrodo 25 (Alfenas, 1998) para os sistemas enzimáticos PO, SKDH, 6PGDH, IDH e ACP, e com o sistema 08 (Alfenas, 1998) para os sistemas enzimáticos PGI, MDH, MR e DIA.

Após elaboração do protocolo para as progênies, selecionourse para utilização os seguintes sistemas enzimáticos: ACP, G6PDH, IDH e 6PGDH no sistema tampão gel/cuba TC; e os sistemas PGI, MDH, DIA, NADHDH e MR no sistema tampão gel/cuba CM. Os sistemas G6PDH e NADHDH foram analisados exclusivamente nas progênies. O sistema MR foi posteriormente descartado da análise, tanto dos adultos como nas progênies, pelo fato de expressar os mesmos locos que a enzima DIA. Notificou-se, após obtenção dos géis com amostras de indivíduos de progênies, que o sistema $\mathrm{MDH}$ não apresentava o mesmo padrão de expressão de bandas observado nos géis contendo amostras dos adultos. Esse sistema apresentou alta complexidade de expressão da enzima, o que tornou difícil a definição na genotipagem, sendo também descartado da análise dos adultos. O sistema PO também foi descartado da análise pelo mesmo motivo. Cabe ressaltar que o padrão de resolução dos géis das amostras de progênies foi superior aos adultos.

A Figura 3 apresenta os padrões izoenzimáticos obtidos, após transparentização, dos 
géis de cada um dos sistemas enzimáticos utilizados, sendo possível identificar o nível de resolução obtido após otimização dos protocolos. Na análise genética das populações adultas, os sete sistemas isoenzimáticos avaliados revelaram um total de oito zonas de atividades que foram passíveis de interpretação. Embora o sistma IDH tenha sido totalmente monomórfico, este foi mantido. Apenas o sistema PGI apresentou duas zonas interpretáveis, sendo observados dois locos polimórficos em estrutura dimérica, onde o da região mais anódica revelou três alelos e o outro dois alelos. A enzima 6PGDH apresentou um loco polimórfico com dois alelos em estrutura dimérica. A SKDH apresentou uma zona de atividade, interpretada como loco polimórfico de expressão monomérica. A ACP apresentadou duas zonas de atividade. Uma delas com baixa resolução não compôs a análise. A PO apresentou uma zona interpretável, sendo esta polimórfica com dois alelos, os quais apresentavam migração oposta no campo eletroforético. Para a DIA foi possível identificar três zonas de atividade, sendo interpretada apenas a região mais anódica nos adultos, pelo fato dos outros dois locos não apresentarem boa resolução. Para esta enzima, nas progênies, todos os locos foram analisados, sendo estes polimórficos com três alelos em cada um. Nos sistemas enzimáticos exclusivos para a progênie, a MDH apresentou dois locos, com dois alelos no loco mais anódico e três alelos no mais catódico. A NADHDH apresentou duas zonas de atividade, em estrutura monomérica, sendo ambos os locos polimórficos com até três alelos por loco. Já a G6PDH, apresentou uma zona de atividade composta por enzima de expressão monomérica com polimorfismo, tendo esta dois alelos. A análise genética das progênies foi composta por 13 locos distribuídos em sete sistemas enzimáticos interpretados. Destes locos, apenas cinco foram utilizados nas análises tanto de adultos como de progênies. A Figura 4 demostra a representação esquemática dos zimogramas adotados na interpretação da bandas reveladas nos géis com amostras da espécie. 

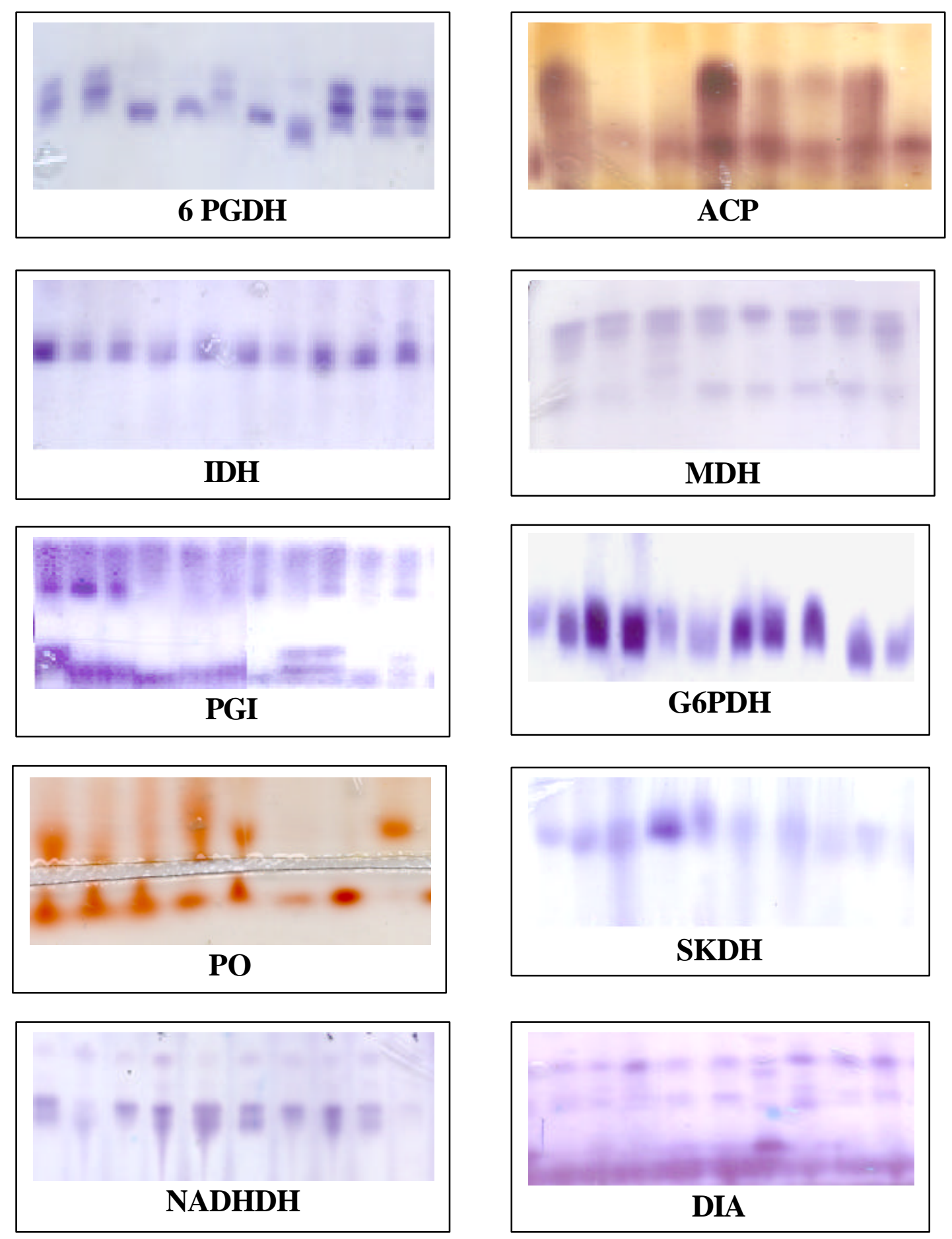

Figura 3 - Amostras de géis de diferentes sistemas izoenzimáticos utilizados para a análise genética de $E$. ovata 

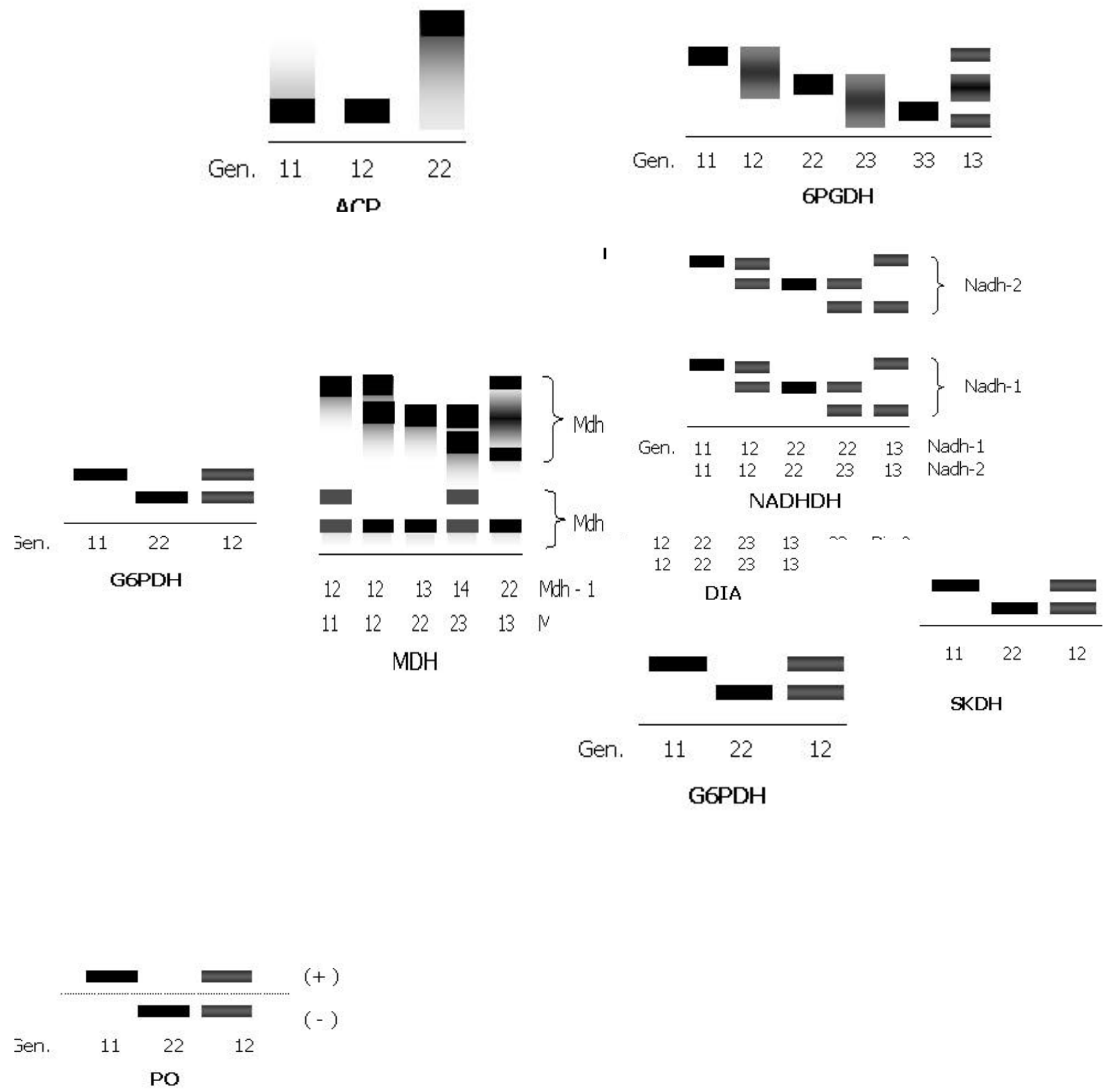

Figura 4 - Representação esquemática da interpretação de bandas dos sistemas enzimaticos analisados para E. ovata. 


\subsection{Sistema de reprodução}

\subsubsection{Teste de Equilíbrio de Hardy-Weinberg}

Inicialmente, abordou-se o sistema de reprodução de E. ovata pelo teste de Equilíbrio de Hardy-Weinberg (EHW) nas populações adultas e nas progênies por meio do uso do teste exato de Fisher (Tabela 1). Este último teste é o mais adequado quando existem freqüências esperadas inferiores a 5\%. Em EHW a frequiência relativa dos alelos deve permanecer a mesma de uma geração para outra, sendo a única mudança possível na composição genética da população a redistribuição dos alelos dentro dos genótipos da nova geração (Futuyma, 1992).

O teste exato de Fisher para o EHW revelou desvios das freqüências genotípicas observadas em relação às esperadas pelo modelo em $57 \%$ dos locos polimórficos (Po, Dia, Skdh e 6pgdh) da população de adultos de Camarugipe, 29\% (Pgi-2 e Skdh) da explorada de Itaparica e 42\% (Pgi-2, Skdh e 6pgdh) da Itaparica com baixa antropização. Nas progênies, o teste de Fisher apresentou desvios de EHW, em 75\% dos locos na população de Camarugipe e em $66 \%$ da população de Itaparica. Portanto, foram detectados desvios de EHW nas populações estudadas, tanto nos adultos como em suas progênies. Desvios do EHW podem ser causados pelo sistema de reprodução ou por fatores evolutivos e genéticos como seleção, migração, deriva genética ou mutação (Sebbenn et al., 2000). O uso do teste de equilíbrio de endogamia de Wright permite separar os efeitos do sistema de reprodução dos fatores evolutivos. Contudo, esse teste só pode ser aplicado em locos com três ou mais alelos, visto que em locos com dois alelos não existem graus de liberdade suficientes para sua execução (um grau de liberdade a mais é perdido na estimativa do coeficiente de endogamia). Como a maioria dos locos que apresentaram desvios do EHW tinha apenas dois alelos, não foi possível aplicar o teste. 
Tabela 1. Probabilidades do teste exato de Fisher para o Equilíbrio de Hardy-Weinberg (EHW) em populações de Eschweleira ovata

\begin{tabular}{|c|c|c|c|c|c|}
\hline \multirow[t]{2}{*}{ Loco } & \multicolumn{2}{|c|}{ CAN } & \multicolumn{2}{|c|}{ ITE } & \multirow{2}{*}{$\begin{array}{c}\text { ITBA } \\
\text { Adultos }\end{array}$} \\
\hline & Adulto & Progênies & Adulto & Progênies & \\
\hline Mdh-1 & ---- & $1,000 \quad$ (2) & $\begin{array}{l}--- \\
-\end{array}$ & 0,917 & ---- \\
\hline Mdh-2 & ---- & $0,010 * *(2)$ & ---- & $0,027 *(2)$ & ---- \\
\hline 6Pgdh & $1,000 *(2)$ & $0,021 *(2)$ & 1,000 & $0,000 * *(2)$ & $0,023 *(1)$ \\
\hline Acp & $1,000 \quad$ (1) & $0,002 * *(1)$ & 0,648 & 0,218 & $0,326 \quad$ (1) \\
\hline G6pdh & --- & $0,000 * *(1)$ & ---- & $0,000 * *$ & ---- \\
\hline Pgi-1 & $0,558 \quad(2)$ & 0,473 & 0,168 & $0,015 *(2)$ & $1,000 \quad(2)$ \\
\hline Pgi-2 & $1,000 \quad(2)$ & $0,000 * *(2)$ & $0,047 *$ & $0,018 *$ & $0,045 *(1)$ \\
\hline Dial & $0,030 *(1)$ & $0,000 * *(2)$ & 1,000 & $0,002 * *(1)$ & 0,700 \\
\hline Dia2 & ---- & $0,028 *(2)$ & ---- & $0,015 *(2)$ & --- \\
\hline Dia3 & ---- & $0,037 *(2)$ & ---- & 0,599 & ---- \\
\hline Nadhdh-1 & --- & $0,042 *(1)$ & ---- & $0,745 * \quad(1)$ & ---- \\
\hline Nadhdh-2 & ---- & 0,592 & ---- & 0,795 & ---- \\
\hline Skdh & $0,021 *(1)$ & ---- & $0,000 * *(1)$ & ---- & $0,005 * *(1)$ \\
\hline Po & $0,020 *(1)$ & ---- & $0,565 \quad(1)$ & ---- & $1,000 \quad(1)$ \\
\hline
\end{tabular}

*: $P \leq 0,05 ; * *: P \leq 0,01$.

( ): graus de liberdade.

\subsubsection{Desequilíbrio de ligação entre pares locos}

Um das pressuposições básicas do modelo de reprodução mista de Ritland \& Jain (1981) é a independência na segregação de alelos de diferentes locos, ou em outros termos, é a presença de equilíbrio de ligação entre os locos utilizados na análise do sistema de reprodução. Assim, em estudos de sistema de reprodução é desejável a avaliação da associação entre locos antes das análises. Na Tabela 2 são apresentados os resultados do teste de qui-quadrado $\left(\chi^{2}\right)$ e a probabilidade para os locos que apresentaram ligação.

Os resultados indicaram associação altamente significativa entre os locos Idh e Pgi2, 6Pgdh e Pgi2, Dia1 e Dia2 e Dia2 e Dia3, sugerindo que estes encontram-se ligados e próximos entre si. Observa-se que os locos Pgi2 e Dia2 encontram-se em todos os grupos de ligações e, a sua exclusão quebra a ligação entre estes grupos, motivo pelo qual foram excluídos da análise do sistema de reprodução. 
Tabela 2. Resumo do teste de qui-quadrado para ligação entre pares de locos conjunto para ambas populações de progênies

\begin{tabular}{lccc}
\hline Locos & $\chi^{2}$ & GL & $P$ \\
\hline Idh e Pgi2 & Infinito & 2 & 0,0000 \\
6Pgdh e Pgi2 & Infinito & 4 & 0,0000 \\
Dia1 e Dia2 & Infinito & 4 & 0,0000 \\
Dia2 e Dia3 & Infinito & 4 & 0,0000 \\
\hline
\end{tabular}

\subsubsection{Frequiências alélicas dos óvulos e pólen}

A estimativa da divergência genética entre as freqüências alélicas dos óvulos e do pólen revelou diferenças significativas para os locos Mdh-2, Pgi-1 e Dia-1 na população natural de Camarugipe e para o loco Mdh-2, Acp e Dia-1 na população explorada de Itaparica (Tabela 3). Diferenças entre as frequiências alélicas do pólen e dos óvulos podem ser atribuídas a diferenças nas funções masculina e feminina das plantas, imigração de pólen de fora das populações amostradas, seleção entre o período de polinização e análise de isoenzimas, devido à amostragem não representativa das árvores maternas (Ritland \& Jain, 1981) e desvios de cruzamentos aleatórios causados por autofecundações, cruzamentos biparentais, cruzamentos endogâmicos (cruzamentos entre indivíduos aparentados) e variação na fenologia de florescimento. Dentre estes fatores, o primeiro é pouco provável já que estudos fenológicos da espécie não demostraram esta ocorrência (Santos, 2003). Os mais prováveis são amostragem não representativa das árvores maternas e desvios de cruzamentos aleatórios. 
Tabela 3. Estimativa das frequiências alélicas, número total de alelos $\left(n_{a}\right)$ e tamanho amostral $(n)$ do pólen e óvulos das progênies de Eschweleira ovata

\begin{tabular}{|c|c|c|c|c|c|c|c|c|c|c|c|c|c|}
\hline \multirow[b]{2}{*}{ Loco } & \multirow[b]{2}{*}{ Alelo } & \multicolumn{6}{|c|}{ Natural } & \multicolumn{6}{|c|}{ Explorada } \\
\hline & & Pólen & Óvulo & $\hat{F}_{S T}$ & $n$ & GL & $\chi^{2}$ & Pólen & Óvulo & $\hat{F}_{S T}$ & $n$ & GL & $\chi^{2}$ \\
\hline \multirow[t]{2}{*}{ Mdh-1 } & 1 & 0,005 & 0,025 & & & & & 0,005 & 0,024 & & & & \\
\hline & 2 & 0,995 & 0,975 & 0,007 & 193 & 1 & 1,31 & 0,995 & 0,976 & 0,006 & 199 & 1 & 1,26 \\
\hline \multirow[t]{3}{*}{ Mdh-2 } & 1 & 0,021 & 0,024 & & & & & 0,051 & 0,005 & & & & \\
\hline & 2 & 0,890 & 0,732 & & & & & 0,660 & 0,925 & & & & \\
\hline & 3 & 0,089 & 0,244 & 0,039 & 194 & 2 & $15,13 * *$ & 0,289 & 0,025 & 0,101 & 188 & 2 & $38,15^{* *}$ \\
\hline \multirow[t]{3}{*}{$6 \mathrm{pgdh}$} & 1 & 0,440 & 0,550 & & & & & 0,384 & 0,405 & & & & \\
\hline & 2 & 0,380 & 0,250 & & & & & 0,396 & 0,336 & & & & \\
\hline & 3 & 0,180 & 0,200 & 0,012 & 192 & 2 & $4, .55$ & 0,220 & 0,260 & 0,009 & 197 & 2 & 3,41 \\
\hline \multirow[t]{2}{*}{ Acp } & 1 & 0,208 & 0,300 & & & & & 0,274 & 0,387 & & & & \\
\hline & 2 & 0,792 & 0,700 & 0,011 & 196 & 1 & 2,19 & 0,726 & 0,613 & 0,054 & 196 & 1 & $10,55^{* *}$ \\
\hline \multirow[t]{2}{*}{ G6pdh } & 1 & 0,444 & 0,400 & & & & & 0,447 & 0,386 & & & & \\
\hline & 2 & 0,556 & 0,600 & 0,002 & 182 & 1 & 0,36 & 0,553 & 0,614 & 0,016 & 196 & 1 & 3,08 \\
\hline \multirow[t]{3}{*}{ Pgi-1 } & 1 & 0,151 & 0,100 & & & & & 0,132 & 0,104 & & & & \\
\hline & 2 & 0,604 & 0,450 & & & & & 0,688 & 0,682 & & & & \\
\hline & 3 & 0,245 & 0,450 & 0,029 & 192 & 2 & $11,20 * *$ & 0,180 & 0,215 & 0,004 & 188 & 2 & 1,63 \\
\hline \multirow[t]{3}{*}{ Dia-1 } & 1 & 0,249 & 0,463 & & & & & 0,582 & 0,429 & & & & \\
\hline & 2 & 0,746 & 0,512 & & & & & 0,418 & 0,572 & & & & \\
\hline & 3 & 0,006 & 0,024 & 0,053 & 179 & 2 & $18,93 * *$ & ---- & --- & 0,096 & 174 & 1 & $16,74 * *$ \\
\hline \multirow[t]{3}{*}{ Dia-3 } & 1 & 0,106 & 0,075 & & & & & 0,029 & 0,052 & & & & \\
\hline & 2 & 0,753 & 0,725 & & & & & 0,864 & 0,845 & & & & \\
\hline & 3 & 0,141 & 0,200 & 0,003 & 169 & 2 & 1.06 & 0,108 & 0,104 & 0,003 & 143 & 2 & 0,96 \\
\hline \multirow[t]{2}{*}{ Nadhdh-1 } & 1 & 0,667 & 0,725 & & & & & 0,877 & 0,876 & & & & \\
\hline & 2 & 0,333 & 0,275 & 0,004 & 100 & 2 & 1,06 & 0,123 & 0,124 & 0,000 & 120 & 1 & 0,00 \\
\hline \multirow[t]{3}{*}{ Nadhdh-2 } & 1 & 0,623 & 0,683 & & & & & 0,629 & 0,656 & & & & \\
\hline & 2 & 0,344 & 0,293 & & & & & 0,365 & 0,329 & & & & \\
\hline & 3 & 0,034 & 0,024 & 0,003 & 149 & 1 & 0,99 & 0,006 & 0,015 & 0,005 & 166 & 2 & 1,52 \\
\hline
\end{tabular}

** $P<0,01 ; P<0,05$. 
4.2.4 Homogeneidade nas freqüências alélicas das árvores adultas das populações e frequiências alélicas dos óvulos e pólen

Na Tabela 4 são apresentados para cada população os resultados da divergência genética entre as frequiências alélicas do pólen que fecundou cada uma das árvores, entre as árvores adultas e o óvulo e entre as árvores adultas e o pólen.

Tabela 4. Estimativa da divergência genética entre as frequiências alélicas do pólen que fecundou as progênies, entre as frequiências alélicas das árvores adultas e os óvulos, e entre as árvores adultas e o pólen em duas populações de Eschweleira ovata

\begin{tabular}{lcccccc}
\hline & \multicolumn{2}{c}{ Heterogeneidade do polen } & \multicolumn{2}{c}{ Adultos vs óvulos } & \multicolumn{2}{c}{ Adultos vs pólen } \\
Loco & Natural & Explorada & Natural & Explorada & Natural & Explorada \\
\hline Mdh-1 & 0,052 & $0,138^{* *}$ & - & - & - & - \\
Mdh-2 & $0,043 * *$ & $0,645^{* *}$ & - & - & - & - \\
6pgdh & $0,164^{* *}$ & $0,255^{* *}$ & $0,024 * *$ & $0,011^{* *}$ & 0,004 & $0,011 * *$ \\
Acp & $0,110^{* *}$ & $0,122^{* *}$ & $0,092^{* *}$ & $0,136^{* *}$ & $0,380^{* *}$ & $0,015 * *$ \\
G6pdh & $0,134^{* *}$ & $0,244^{* *}$ & - & - & - & - \\
Pgi-1 & $0,070 * *$ & $0,153^{* *}$ & $0,033^{* *}$ & 0,002 & $0,018^{* *}$ & $0,009 *$ \\
Dia-1 & $0,084 * *$ & $0,170^{* *}$ & $0,011^{* *}$ & $0,045^{* *}$ & $0,123 * *$ & $0,011 * *$ \\
Dia-3 & $0,096^{* *}$ & $0,127^{* *}$ & - & - & - & - \\
Nadh-1 & $0,114^{*}$ & $0,157^{* *}$ & - & - & - & - \\
Nadh-2 & $0,115^{*}$ & $0,125^{* *}$ & - & - & - & - \\
\hline
\end{tabular}

Todos os locos, nas duas populações apresentaram divergência genética $\left(\hat{F}_{S T}\right)$ significativa entre as frequiências alélicas do pólen que fecundou cada uma das árvores maternas, com exceção do loco Mdh-1 na população natural. Isto demonstra que o pólen que fecundou as árvores não era homogêneo e indica que os cruzamentos não foram aleatórios. A homogeneidade nas frequiências alélicas é um dos pressupostos básicos do modelo de reprodução mista de Ritland \& Jain (1981). Contudo, desvios desta pressuposição abrem espaço para o entendimento de outros fatores do processo de reprodução. Por exemplo, a heterogeneidade nas frequiências alélicas pode ser causada por cruzamentos biparentais, que por sua vez, podem estar associados à pequenas vizinhanças. Outra causa pode ser a variação espacial e temporal entre árvores na 
fenologia de florescimento e fecundidade (Mitton, 1992) e a proporção de árvores adultas que se reproduzem dentro da estação (Murawski \& Hamrick, 1991).

A comparação entre as frequiências alélicas das árvores adultas e os óvulos e das árvores adultas e o pólen foram significativas, revelando divergência genética $\left(\hat{F}_{S T}\right)$ significância em quase todos os locos, com exceção do loco Pgi-1 na população explorada e 6pgdh na população natural. Estes resultados indicam que as 20 árvores maternas amostradas em cada população não representavam as árvores adultas das populações, em termos de frequiências alélicas. Portanto, neste caso seria necessário um número maior de árvores maternas, provavelmente, 50 a 60 árvores seriam suficientes, considerando os resultados obtidos por ElKassaby \& Sziklai (1983) e Sebbenn (2002), que estudaram o efeito da amostragem para representar frequiências alélicas em populações de espécies arbóreas. Contudo, tendo em vista o alto custo e a dificuldade de genotipar progênies de 50 a 60 árvores de uma simples população, acredita-se que a coleta de sementes em 30 a 35 árvores já seria suficiente.

A heterogeneidade nas frequiências alélicas das árvores adultas e do pólen também indica que este último não era uma amostra representativa da população. A causa pode ser atribuída a cruzamentos biparentais, autofecundações, cruzamentos entre parentes e a fluxo de pólen de fora da população. É difícil determinar qual foi a real causa, mas provavelmente todos estes fatores podem ter contribuído para este resultado.

Ressalta-se que, embora tenham sido detectados desvios das pressuposições do modelo de reprodução mista, segundo Ritland \& Jain (1981), tais desvios têm pouco efeito nas estimativas multiloco de cruzamento, sendo a pressuposição de ausência de ligação entre locos a mais importante.

\subsubsection{Taxa de cruzamento multiloco e uniloco}

A estimativa da taxa de cruzamento multiloco (Tabela 5) foi de 0,999 na população natural e 0,985 na população explorada. Estas estimativas não foram significativamente diferentes da unidade, podendo ser consideradas altas em ambas as populações e indicando que a espécie se reproduz predominantemente por cruzamento. 
Tabela 5. Estimativa de parâmetros do sistema de reprodução em uma população de E. ovata

\begin{tabular}{lcc}
\hline \multirow{2}{*}{ Parâmetros } & \multicolumn{2}{c}{ Populações } \\
\cline { 2 - 3 } & $0,999(0,004)$ & $0,985(0,023)$ \\
\hline Taxa de cruzamento multiloco $\left(\hat{t}_{m}\right)$ & $0,933(0,011)$ & $0,912(0,017)$ \\
Taxa de cruzamento uniloco $\left(\hat{t}_{s}\right)$ & $0,066(0,012)$ & $0,073(0,016)$ \\
Taxa de cruzamento entre aparentados $\left(\hat{t}_{m}-\hat{t}_{s}\right)$ & $0,107(0,001)$ & $0,100(0,008)$ \\
Correlação de autofecundação $\left(\hat{r}_{s}\right)$ & $0,577(0,088)$ & $0,423(0,070)$ \\
Correlação de paternidade $\left(\hat{r}_{P}\right)$ & 1,7 & 2,4 \\
№ médio de árvores doadoras de pólen $\left(1 / \hat{r}_{P}\right)$ & $0,2 \%$ & $2,2 \%$ \\
Proporção de irmãos de autofecundação $\left(\hat{P}_{I A}\right)$ & $57,6 \%$ & $41,7 \%$ \\
Proporção de irmãos-completos $\left(\hat{P}_{I C}\right)$ & $42,2 \%$ & $56,8 \%$ \\
Proporção de meios-irmãos $\left(\hat{P}_{M I}\right)$ & $0,032[-0,224$ a 0,254$]$ & $0,193[-0,020$ a 0,441$]$ \\
Índice de fixação na árvores adultas $(\hat{F})$ & $0,071[-0,0520$ a & $0,061[-0,0784$ a \\
Índice de fixação nas progênies $\left(\hat{F}_{p}\right)$ & $0,1750]$ & $0,1864]$ \\
Coancestria dentro de progênies $\left(\hat{\boldsymbol{\theta}}_{F}\right)$ & 0,211 & 0,191 \\
Tamanho efetivo de variância $\left(\hat{N}_{e(v)}\right)$ & 2,05 & 2,22 \\
Número de matrizes para reter o $\hat{N}_{e}=50(\hat{m})$ & 25 & 23 \\
\hline [ ] Intervalo de confiança a 95\% de probabilidade, obtido por 10.000 reamostragens $($ bootstrap $)$ \\
sobre locos. \\
( ) Erro padrão da média, obtido por 500 reamostragens $($ bootstrap $)$.
\end{tabular}

A taxa de cruzamento uniloco foi menor do que a taxa de cruzamento multiloco, com valores de 0,933 na população natural e 0,912 na explorada. Estas estimativas da taxa de cruzamento sugerem ausência de mecanismos de auto-incompatibilidade na espécie. Comparando estes resultados com a estimativa da taxa de cruzamento multiloco, calculada para a média das espécies arbóreas tropicais $(0,880 \pm 0,040$; Sebbenn, 2001), observa-se que os valores obtidos para as populações estudadas da espécie E. ovata são levemente superiores a este, diferindo estatisticamente em ambas as populações estudadas. Altas estimativas de cruzamentos são prerrogativas de alta taxa de recombinação e, portanto, predizem que a espécie apresenta alta variabilidade genética. A reprodução por cruzamentos favorece a recombinação e a formação de ampla variedade de genótipos, os quais podem 
conferir alto potencial evolutivo para as espécies e fazer frente à seleção natural nos mais diversos ambientes de ocorrência de uma espécie.

A Tabela 6 apresenta a taxa de cruzamento individual em ambas as populações. Verifica-se que estas apresentaram grande variação entre plantas.

Tabela 6. Estimativa da taxa de cruzamento multiloco individual por planta materna $(\hat{t}) \mathrm{em}$ população de E. ovata

\begin{tabular}{cccccc}
\hline & \multicolumn{2}{c}{ Pop. CAN } & Pop. ITE & $\hat{t}$ \\
Progênies & $n$ & $\hat{t}$ & Progênies & $n$ & $0,91(0,09)$ \\
1 & 10 & $1,00(0,00)$ & 1 & 10 & $0,33(0,17)$ \\
2 & 10 & $1,00(0,00)$ & 2 & 10 & $1,00(0,00)$ \\
3 & 10 & $0,41(0,18)$ & 3 & 10 & $1,00(0,00)$ \\
4 & 10 & $1,00(0,00)$ & 4 & 10 & $0,93(0,08)$ \\
5 & 10 & $1,00(0,04)$ & 5 & 10 & $1,00(0,00)$ \\
6 & 10 & $0,39(0,23)$ & 6 & 10 & $1,00(0,00)$ \\
7 & 10 & $0,98(0,07)$ & 7 & 10 & $1,00(0,00)$ \\
8 & 10 & $1,00(0,00)$ & 8 & 10 & $1,00(0,00)$ \\
9 & 10 & $0,53(0,18)$ & 9 & 10 & $0,32(0,21)$ \\
10 & 10 & $1,00(0,00)$ & 10 & 10 & $1,00(0,05)$ \\
11 & 10 & $0,97(0,06)$ & 11 & 10 & $0,91(0,09)$ \\
12 & 10 & $0,99(0,10)$ & 12 & 10 & $0,96(0,10)$ \\
13 & 10 & $0,82(0,13)$ & 13 & 10 & $0,71(0,15)$ \\
14 & 10 & $0,92(0,09)$ & 14 & 10 & $0,91(0,10)$ \\
15 & 10 & $1,00(0,00)$ & 15 & 10 & $0,72(0,23)$ \\
16 & 10 & $0,98(0,11)$ & 16 & 10 & $1,00(0,00)$ \\
17 & 10 & $1,00(0,00)$ & 17 & 10 & $1,00(0,00)$ \\
18 & 10 & $1,00(0,03)$ & 18 & 10 & $1,00(0,00)$ \\
19 & 10 & $1,00(0,00)$ & 19 & 10 & $0,83(0,13)$ \\
20 & 10 & $1,00(0,00)$ & 20 &
\end{tabular}

( ): Intervalo de confiança, a 95\% de probabilidade pelo teste t de Student.

[ ]: Erro padrão da média, obtido por 1.000 reamostragens (bootstrap) sobre locos

Na população natural a taxa de cruzamento variou de 0,39 a 1,0 e na explorada de 0,32 a 1,0. Entretanto, apenas $10 \%$ das estimativas em ambas as populações foram menores do que 0,5 . E ainda, $20 \%$ das estimativas obtidas na população natural e $25 \%$ na explorada, foram estatisticamente diferentes de um, reforçando que a espécie se reproduz por sistema misto com predomínio de cruzamentos e que, provavelmente, não existe autoincompatibilidade na espécie. 


\subsubsection{Taxa de cruzamento entre parentes}

A diferença entre a taxa de cruzamento multiloco e uniloco $\left(\hat{t}_{m}-\hat{t}_{s}\right)$ tem sido utilizada para quantificar a ocorrência de cruzamentos endogâmicos ou, em outros termos, entre indivíduos aparentados. Os resultados aqui obtidos revelaram cruzamento entre parentes em ambas as populações, sendo de 0,066 na população natural e de 0,073 na explorada (Tabela 5). Estes valores não diferem-se estatisticamente entre si e podem ser considerados moderadamente baixos, porém em ambas as populações estes são significativamente diferente de zero. O cruzamento entre parentes, além da autofecundação, é outra foram de geração de endogamia nas populações de espécie arbóreas, embora seus efeitos sejam mais brandos do que os efeitos da autofecundação. Tendo em vista que a endogamia observada nas progênies $\left(\hat{F}_{p}\right)$ da população natural foi de 0,071 , e que a endogamia pode ser gerada por autofecundações $\left(1-\hat{t}_{m}\right)$ e por cruzamentos entre parentes, somando-se a taxa de autofecundação a taxa de cruzamento entre parentes, conclui-se que praticamente $100 \%$ dessa endogamia foi gerada por cruzamento entre parentes. Aplicando o mesmo raciocínio de cálculo com os dados da população explorada, determina-se ser 76,8\% da endogamia, gerada por cruzamentos entre parentes, sendo o restante atribuído à autofecundação. Ainda, visto que em espécies de cruzamentos, a endogamia nas progênies é igual a coancestria entre os parentais cruzados (Lindgren et al., 1997), pode-se dizer que o parentesco entre as plantas responsáveis pela taxa de cruzamento entre aparentados foi próximo a primos de primeiro grau $(0,0625)$, ou resumidamente, existe parentesco nas populações sendo esse em média próximo ao esperado entre primos de primeiro grau. 


\subsubsection{Taxa de cruzamentos correlacionados}

As estimativas das correlações de autofecundação $\left(\hat{r}_{s}\right)$, ou a probabilidade de encontrar um indivíduo gerado por autofecundação onde foi encontrado outro indivíduo de autofecundação, foram relativamente baixas em ambas as populações e não diferentes estatisticamente entre si, tendo apresentado valores de 0,107 (†0,001) para a população natural e $0,100(-0,008)$ na população explorada. Este resultado sugere que não existe forte tendência de algumas plantas maternas deixarem mais descendentes por autofecundação ou cruzamentos do que outra, estando os indivíduos advindos de autofecundação, distribuídos aleatoriamente dentro das progênies. Isto reforça novamente a possibilidade da espécie ser autocompatível.

A correlação $r_{p}$ mede a proporção de indivíduos de cruzamentos que foram gerados por cruzamentos biparentais (irmãos-completos) (Ritland 1989). A estimativa da correlação $r_{p}$ em E. ovata (Tabela 5) foi elevada e significativamente diferente de zero, nas duas populações, sendo de $0,577^{ \pm} 0,088$ e $0,423^{ \pm} 0,070$, respectivamente, para a população de natural e explorada. Também se verificou que elas não se diferiram estatisticamente. Estes resultados sugerem que uma parte das progênies de cruzamentos foram geradas pelo mesmo parental materno e paterno, indicando haver a presença de cruzamentos biparentais dentro das populações. Assim, as progênies oriundas de cruzamentos não são compostas por meiosirmãos exclusivamente, mas também por irmãos completos. Sun \& Ritland (1998), atribuem as causas dos cruzamentos biparentais: ao comportamento dos polinizadores, visitando de forma sistemática árvores próximas; ao pequeno número de vizinhos próximos; e ao assincronismo no florescimento das árvores. Além disso, em algumas espécies pode ocorrer poliandria ou o depósito de múltiplos grãos de pólen de um simples polinizador (Muana et al., 1991). Variações ambientais podem também afetar o comportamento e/ou a densidade das populações de polinizadores, levando à alterações na taxa de cruzamento das espécies em diferentes populações (Murawski, 1995).

Souza et al. (2003) afirmam que o sistema misto de reprodução normalmente é 
conceituado como a mistura de cruzamentos aleatórios e autofecundações, porém, esta conceituação desconsidera a ocorrência de cruzamentos biparentais, que é outra forma de reprodução a qual também pode causar desvios de cruzamentos aleatórios, mesmo em espécies obrigatoriamente de cruzamento (espécies dióicas). Em Cariniana legalis Mart. O. Ktze. (Sebbenn et al 2000), espécie da mesma família da E. ovata, as correlações de paternidade variaram entre populações de 0,212 a 0,324. Em populações de Esenbeckia leiocarpa Engl. (Seoane et al., 2001) as estimativas das correlações de paternidade variaram de 0,749 a 0,986, sendo estas umas das mais altas detectadas em espécies arbóreas tropicais. Em Tabebuia cassinoides (Lam.) A.P. de Candolle (Sebbenn et al. 2001) foi detectada maior correlação de paternidade em uma população natural $(0,547)$, em comparação a uma população explorada $(0,295)$. Apesar das correlações não diferirem estatisticamente entre si, nota-se a mesma ocorrência nas populações de E. ovata estudadas, ou seja, maior $r_{p}$ na população não explorada, sendo ambas as espécies com comportamento muito semelhante com relação ao adensamento demográfico. Em concordância com estes estudos, Murawski \& Hamrick (1991) observaram que em populações de espécies arbóreas de baixa densidade, o pólen dos cruzamentos era menos diversificado do que em espécies de alta densidade. Estudo recente realizado com Pachira quinta (Jacq.) Alverson (Fuchs et al., 2003), uma espécie arbórea tropical das florestas da Costa Rica, comparando a estimativa da correlação de paternidade em uma população adensada em relação à outra com 15 árvores, distantes por pelo menos 500 m entre si, detectou $r_{p}$ de 0,470 para a população adensada e 0,740 para a de árvores isoladas. Os autores atribuíram a maior correlação de paternidade na última população ao isolamento das árvores e a baixa densidade populacional.

A partir da correlação de paternidade é possível estimar o número médio de indivíduos polinizadores efetivos por árvore $\left(1 / \hat{r}_{p}\right)$, ou seja, a média do número provável de indivíduos que contribuíram com pólen no evento de reprodução de uma árvore-mãe. Os números de indivíduos polinizadores efetivos foram extremamente baixo, tendo em média, dois indivíduos por árvore. Estudos semelhantes sobre o sistema de reprodução em espécies arbóreas tropicais, corroboram com este resultado. Alves et al. (2003) estudando uma 
população de Teobroma grandiflorum (Willd. \& Spreng.) Schum. encontraram que o número médio de polinizadores era de um a dois indivíduos. Moraes et al. (2003 - no prelo), estudando duas populações de Myracrodruon urundeuva Fr. All, no sudeste do Brasil, detectaram de dois a três polinizadores efetivos. Resultados próximos ao encontrado também foram observados em Eucalyptus rameliana F. Muell (Sampson, 1998), Picea mariana (Mill.) BSP (Perry \& Bosquet (2001) e Grevillea iaspicula McGill (Hoebee \& Young, 2001). Estes resultados vêm de encontro com a teoria geral de que a polinização natural em espécies arbóreas é realizada a partir de grande número de plantas.

Combinando a correlação de paternidade $\left(\hat{r}_{p}\right)$ com a taxa de cruzamento multiloco $\left(\hat{t}_{m}\right)$ é possível conhecer a proporção dos diferentes tipos de parentesco dentro das progênies. A proporção de irmãos de autofecundação foi nula na população natural e de apenas 2,2\% na população explorada. A proporção de irmãos-completos foi de 56,6\% e 41,7\% nas populações natural e explorada, respectivamente, e a proporção de meios-irmãos foi de $42,2 \%$ e 56,8\% nas populações natural e explorada, respectivamente. Estes resultados demostram que as progênies de E. ovata da população natural são compostas em maior proporção por irmãos-completos, enquanto que na população explorada a proporção de meios-irmãos é maior.

\subsection{8 Índices de fixação}

O índice de fixação de Whight (1965) mede a relação entre a heterozigosidade observada e a esperada em uma população de cruzamentos aleatórios, conforme as expectativas do EHW. Na população de natural, a estimativa do índice de fixação mostrou maior endogamia nas progênies $\left(F_{p}=0,071\right)$, em comparação às árvores adultas $(\hat{F}=0,032)$. O mesmo não ocorreu na população de manejada, onde o valor de $\hat{F}(0,193)$ é consideravelmente maior que $F_{p}(0,061)$. Contudo, o índice de fixação nas árvores adultas e nas progênies de ambas as populações não foram estatisticamente diferentes de zero e entre si. O índice de fixação verificado na população natural sugere que está ocorrendo seleção contra 
homozigotos, visto que a endogamia nas progênies foi superior à observada nos adultos. Resultado semelhante tem sido observado em diversos estudos comparando gerações de árvores tropicais adultas com suas progênies (Sebbenn et al., 2001; Seoane at al., 2001; Souza et al, 2003; Alves at al., 2003).

Em arbóreas de fecundação cruzada, a endogamia pode ter efeitos negativos sobre a capacidade adaptativa e reprodutiva de populações pequenas, sendo estes efeitos incrementados pela sobreposição de gerações. Em populações pequenas, na ausência de seleção contra homozigotos, a taxa de endogamia e parentesco pode crescer rapidamente, levando à depressão endogâmica. Suas principais características são a perda de vigor, fertilidade, capacidade de adaptação e reprodução (Allard, 1970).

\subsubsection{Coeficiente de coancestria e tamanho efetivo de variância}

Em concordância com as estimativas da correlação de paternidade, o valor estimado para o coeficiente de coancestralidade dentro de progênies da população natural $\left(\hat{\boldsymbol{\Theta}}_{F}=0,211\right)$ e explorada $\left(\hat{\boldsymbol{\theta}}_{F}=0,191\right)$ atingiu valores relativos $40,8 \%$ e $34,5 \%$ superiores ao esperado em progênies de meios-irmãos $(0,125)$. A maior coancestria na população natural pode ser atribuída a maior correlação de paternidade, ou seja, a maior proporção de cruzamentos biparentais, sendo a maioria das progênies geradas, aparentadas no grau de irmãoscompletos.

Vale ressaltar que na população explorada foi detectada taxa de cruzamento entre indivíduos aparentado de 7,3\% e na natural de 6,6\%, podendo-se, assim, dizer que uma parte pequena, porém significativa, das progênies geradas por cruzamentos aleatórios e biparentais, devem ser aparentadas em grau superior ao de meios-irmãos e irmãos-completos.

O coeficiente de coancestria $(\hat{\theta})$ tem papel central, em programas de melhoramento e conservação genética, na estimativa do coeficiente de correlação parentesco $\left(r_{x y}\right)$ entre plantas dentro de progênies e tamanho efetivo de variância. O coeficiente de correlação é a base do cálculo da variância genética aditiva e coeficientes de herdabilidade e ganho na 
seleção. Em espécies de cruzamentos, o coeficiente de correlação de parentesco é o dobro do coeficiente de coancestria $\left(r_{x y}=2 \theta_{x y}\right)$, de forma que alterações na coancestria geram simultaneamente alterações no coeficiente de correlação de parentesco. Em progênies perfeitamente de meios-irmãos o coeficiente de parentesco estima $25 \%$ da variação genética aditiva. No presente trabalho a correlação de parentesco estimada do coeficiente de coancestria corresponde a 0,422 e 0,382, na população natural e explorada, respectivamente. Portanto, em termos de melhoramento, os coeficientes de correlação estimados indicam que assumir progênies de meios-irmãos para a estimativa de parâmetros genéticos irá gerar superestimativas na variância genética aditiva e parâmetros a fins.

O tamanho efetivo de variância mede a representatividade genética de uma população, em função de alterações nas frequiências alélicas entre gerações, devido efeitos da deriva genética. O sistema misto de reprodução tem implicações na estimativa do tamanho efetivo de variância $\left(N_{e(v)}\right)$, devido à endogamia causada por autofecundações e pelos cruzamentos entre aparentados, além da representatividade genética diminuir por causa da menor diversidade de indivíduos polinizadores (plantas doadoras de pólen). Os valores estimados para o $N_{e(v)}$ foram de 2,05 para a população natural, e 2,22 para a explorada. Estes valores são basicamente a metade do valor teórico máximo esperado (aproximadamente quatro) em uma simples progênie de uma população idealizada (tamanho infinito, praticando cruzamentos aleatórios, sem seleção, mutação e migração).

O tamanho efetivo de 50 tem sido sugerido como suficiente para manter o coeficiente de endogamia a uma taxa de $1 \%$ por geração, até 10 gerações, em locos com dois alelos, em populações de espécies com gerações discretas (Frankel \& Soulé, 1981). Através das estimativas do tamanho efetivo de variância $\left(N_{e(v)}\right)$, foi possível estimar o número de matrizes necessárias para reter um $N_{e}$ igual a 50 para $E$. ovata, sendo este número calculado pela

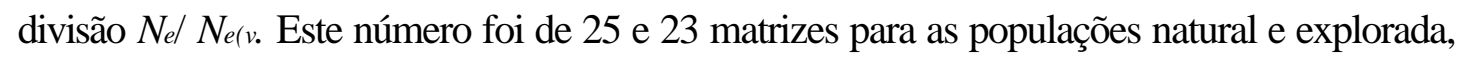
respectivamente. Assim, havendo interesse na conservação ex situ a curto prazo da espécie, aproximadamente 25 indivíduos seria o número médio mínimo de árvores matrizes de uma população a ser considerado na coleta de sementes para a formação de um banco ativo de 
germoplasma. Este número é basicamente o dobro do sugerido em literatura, e comumente utilizado como referência na coleta de sementes para formação de mudas a serem utilizadas em plantios de restauração florestal.

O tamanho de 50 conserva muito dos genes de uma população e pode ser suficiente para evitar os danos da depressão por endogamia a curto prazo, mas não é suficiente para manter por longo tempo grande proporção da variação genética (Sebbenn, 2002). Com o propósito a conservação genética a longo prazo, Franklin (1980) sugeriu o tamanho efetivo de 500, o qual para a espécie seria representada por um número de aproximadamente 244 árvores matrizes.

\section{3 Estrutura genética}

\section{3. 1 Freqüiências alélicas}

As estimativas das frequiências alélicas das populações de indivíduos adultos e progênie de E. ovata são apresentadas na Tabela 7. Observa-se algumas alterações nas frequiências alélicas entre populações. No loco Pgi-1 a frequiência do alelo 2 apresenta-se elevada sobre os alelos 1 e 3 em todas as populações, ocorrendo o mesmo com o alelo 1 do loco Pgi-2. Moderadas alterações nas frequências alélicas são também observadas no locos Dia-1, Dia-2 e Nadhdh-2 e Nadhdh-1, exceto este último na população explorada, apresentando maior freqüência do alelo 1, e no loco Po com maior frequência do alelo 2, exceto na população explorada. Alterações maiores nas frequiências alélicas são observadas nos locos Acp, Mdh-1, Mdh-2, Dia-3, tendo o alelo 2 destes locos elevada freqüência sobre os demais. As frequiências alélicas apresentaram-se equalitariamente distribuídas nos locos 6pgdh, G6pdh na população natural, no loco Skdh 1, nas populações de baixa antropização, e no loco 6pgdh-1, na população explorada. No demais locos nas populações, estes apresentaram posições intermediárias de distribuição.

Alelos exclusivos foram detectados nas árvores adultas da população natural (alelo 3 no loco Pgi-2) e nas progênies, no loco Dia-1 (alelo 3) na população natural e Pgi-2 (alelo 4) na população explorada. Os alelos exclusivos observados nas progênies não estavam 
presentes nas árvores adultas dessas populações. A causa pode estar associada ao tamanho da área de amostragem das árvores adultas ou a fluxo de genes de fora das populações.

Tabela 7. Estimativa de frequiências alélicas em adultos e progênies de Eschweleira ovata

\begin{tabular}{|c|c|c|c|c|c|c|}
\hline \multirow[b]{2}{*}{ Loco } & \multirow[b]{2}{*}{ Alelo } & \multicolumn{3}{|c|}{ Adultos } & \multicolumn{2}{|c|}{ Progênies } \\
\hline & & CAN & ITE & ITBA & CAN. & ITE \\
\hline Idh & 1 & ---- & ---- & ---- & 1,000 & 1,000 \\
\hline \multirow[t]{3}{*}{ Mdh-1 } & 1 & ---- & ---- & ---- & 0,010 & 0,056 \\
\hline & 2 & ---- & --- & ---- & 0,820 & 0,787 \\
\hline & 3 & ---- & --- & ---- & 0,170 & 0,157 \\
\hline \multirow[t]{2}{*}{ Mdh-2 } & 1 & ---- & --- & ---- & 0,008 & 0,003 \\
\hline & 2 & ---- & ---- & ---- & 0,992 & 0,997 \\
\hline \multirow[t]{3}{*}{ 6Pgdh } & 1 & 0,362 & 0,290 & 0,394 & 0,490 & 0,409 \\
\hline & 2 & 0,404 & 0,355 & 0,221 & 0,315 & 0,338 \\
\hline & 3 & 0,234 & 0,355 & 0,385 & 0,195 & 0,254 \\
\hline \multirow[t]{2}{*}{ Acp } & 1 & 0,074 & 0,173 & 0,327 & 0,242 & 0,385 \\
\hline & 2 & 0,926 & 0,827 & 0,673 & 0,758 & 0,615 \\
\hline \multirow[t]{2}{*}{ G6pdh } & 1 & ---- & ---- & ---- & 0,420 & 0,388 \\
\hline & 2 & ---- & --- & ---- & 0,580 & 0,612 \\
\hline \multirow{3}{*}{ Pgi-1 } & 1 & 0,298 & 0,079 & 0,255 & 0,135 & 0,114 \\
\hline & 2 & 0,457 & 0,632 & 0,592 & 0,518 & 0,665 \\
\hline & 3 & 0,245 & 0,289 & 0,153 & 0,346 & 0,231 \\
\hline \multirow[t]{4}{*}{ Pgi-2 } & 1 & 0,764 & 0,658 & 0,638 & 0,558 & 0,640 \\
\hline & 2 & 0,198 & 0,342 & 0,362 & 0,386 & 0,229 \\
\hline & 3 & 0,038 & ---- & ---- & 0,056 & 0,123 \\
\hline & 4 & ---- & --- & ---- & --- & 0,008 \\
\hline \multirow[t]{2}{*}{$\mathrm{PO}$} & 1 & 0,302 & 0,404 & 0,264 & & \\
\hline & 2 & 0,698 & 0,596 & 0,736 & & \\
\hline \multirow[t]{3}{*}{ Dia-1 } & 1 & 0,578 & 0,476 & 0,661 & 0,394 & 0,422 \\
\hline & 2 & 0,422 & 0,524 & 0,339 & 0,603 & 0,578 \\
\hline & 3 & ---- & ---- & ---- & 0,003 & --- \\
\hline \multirow[t]{3}{*}{ Dia-2 } & 1 & ---- & --- & ---- & 0,178 & 0,244 \\
\hline & 2 & ---- & ---- & ---- & 0,647 & 0,659 \\
\hline & 3 & ---- & ---- & ---- & 0,175 & 0,096 \\
\hline \multirow[t]{3}{*}{ Dia-3 } & 1 & ---- & --- & ---- & 0,083 & 0,035 \\
\hline & 2 & ---- & ---- & ---- & 0,757 & 0,846 \\
\hline & 3 & ---- & --- & ---- & 0,160 & 0,119 \\
\hline \multirow[t]{2}{*}{ Nadhdh-1 } & 1 & ---- & --- & ---- & 0,665 & 0,883 \\
\hline & 2 & ---- & --- & ---- & 0,335 & 0,117 \\
\hline \multirow[t]{3}{*}{ Nadhdh-2 } & 1 & ---- & ---- & ---- & 0,648 & 0,654 \\
\hline & 2 & ---- & ---- & ---- & 0,336 & 0,343 \\
\hline & 3 & ---- & --- & ---- & 0,017 & 0,003 \\
\hline
\end{tabular}

Em geral, as frequiências alélicas não foram extremamente diferentes entre populações, indicando que a divergência genética deve ser baixa entre estas e a diversidade genética dentro 
das populações deve ser alta. Frankel et al. (1995) afirmam ser a maior equidade nas frequiências alélicas de uma população um indicador de maior diversidade genética, estando estas populações mais protegidas dos efeitos da deriva genética se comparadas às que têm alelos muito menos freqüientes do que outros.

\subsubsection{Distribuição da diversidade genética entre e dentro de populações}

\subsubsection{Divergência genética entre populações}

Estimativas da divergência genética entre populações de adultos e progênies, com base em medidas de coancestria de Weir \& Cockerham (1984), são apresentadas na Tabela 8. A divergência genética entre as populações de adultos, ou o coeficiente de coancestria entre dois indivíduos dentro de populações $\left(\hat{\theta}_{p A}\right)$, foi de apenas 2,5\% (variação de 1,4 \% a 5,5\%), indicando que a maior parte da diversidade genética encontra-se distribuída dentro das populações $(97,5 \%)$. A divergência entre populações, estimada com base nas progênies $\left(\hat{\theta}_{p P}\right)$ foi ainda menor, de $1,4 \%(0,1$ a 3,5$)$, confirmando que a maior parte da diversidade genética reside dentro de populações. Contudo, apesar dos baixos valores, para as populações de adultos, estes foram significativamente diferentes de zero, a 99\% de probabilidade. Baixos valores de divergência genética eram esperados, visto que não foram observadas diferenças contrastantes nas frequiências alélicas entre populações.

A divergência genética entre progênies dentro de populações $\left(\hat{\theta}_{p p}\right)$, entre progênies

dentro da população natural $\left(\hat{\theta}_{p p 1}\right)$ e dentro da população explorada $\left(\hat{\theta}_{p p 2}\right)$ foram de 0,149 , 0,118 e 0,162, respectivamente. Em progênies perfeitamente de meios-irmãos, como anteriormente comentado na análise do sistema de reprodução, o coeficiente de coancestria assume o valor de 0,125. Assim, as coancestria estimadas para a média das populações e população explorada, indicam igualmente como detectado anteriormente, que as progênies não são exclusivamente formadas por meios-irmãos, sendo possivelmente misturas de meiosirmãos, irmãos-completos e irmãos de autofecundação. A diferença entre a coancestria estimada anteriormente e a atual está associada ao método de estimação, sendo esta baseada 
na análise de variância de frequiências alélicas e a anterior com base na probabilidade de identidade por descendência combinada com freqüências de ocorrência dos diferentes tipos de progênies.

Tabela 8. Divergência genética entre populações e progênies

\begin{tabular}{lc}
\hline \multicolumn{1}{c}{ Parâmetros } & Estimativa \\
\hline Divergência entre populações - adultos - $\hat{\theta}_{p A}$ & $0,025(0,014 \text { a } 0,055)^{\mathrm{a}}$ \\
Divergência entre populações - progênies - $\hat{\theta}_{p P}$ & $0,014(-0,001$ a 0,035) \\
Divergência entre progênies/populações - $\hat{\theta}_{p p}^{\mathrm{b}}$ & $0,140(0,104$ a 0,175) \\
Divergência entre progênies/população natural - $\hat{\theta}_{p p 1}^{\mathrm{b}}$ & $0,112(0,085 \mathrm{a} 0,139)^{\mathrm{b}}$ \\
Divergência entre progênies/população explorada - $\hat{\theta}_{p p 2}$ & $0,145(0,098 \mathrm{a} 0,193)^{\mathrm{b}}$ \\
\hline
\end{tabular}

a e b: Intervalo de confiança a $99 \%$ e $95 \%$ de probabilidade, respectivamente, obtido por 10.000 reamostragens (bootstrap) sobre locos.

\subsubsection{Distância genética entre populações}

A divergência genética entre pares de populações, calculada com base no método de Weir \& Cockerham (1984) e a distância genética de Nei (1978) são apresentadas na Tabela 9. Ambos os estimadores mostram que existe pouca diferença entre os pares de populações. Contudo, todas as divergências genéticas foram significativamente diferentes de zero a 95\% de probabilidade. É possível observar que as populações mais próximas geograficamente apresentaram menor distância genética do que populações distantes, sugerindo um agrupamento ao modelo de isolamento por distância de Wright (1943), embora a medida de divergência genética não confirme este padrão. Apesar de ser praticamente inexpressiva, notase ser a divergência genética entre a população explorada de Itaparica mais semelhante à população de Camarujipe do que da área vizinha (ITBA). Contudo, em geral, as distâncias e 
divergência foram todas baixas, confirmando que a maior parte da diversidade encontra-se dentro das populações.

Tabela 9. Matriz de distâncias genéticas não viesadas de Nei (1978) (diagonal superior) e divergência genética entre populações

\begin{tabular}{lccc}
\hline & CAN & ITE & ITBA \\
\hline CAN & - & 0,017 & 0,026 \\
ITE & $0,021 * *$ & - & 0,015 \\
ITBA & $0,034 * *$ & $0,024 *$ & - \\
\hline
\end{tabular}

* e **: Significativo a 95\% e $99 \%$ de probabilidade, respectivamente, a partir de 10.000 reamostragens bootstrap.

\subsubsection{Diversidade genética intrapopulacional}

E. ovata apresenta altos níveis de diversidade genética intrapopulacional (Tabela 10). O número médio de alelos por locos foi de 2,14 nos adultos e de 2,41 nas progênies. A porcentagem de locos polimórficos nas árvores adultas foi de 85,4\% e nas progênies de 81,8\%. A heterozigosidade esperada segundo as expectativas do EHW variaram de 0,354 (progênies da população explorada) a 0,431 (adultos da população de baixa antropização) e a heterozigosidade observada variou de 0,332 (progênies da população explorada) a 0,371 (adultos da população natural), sendo esta em todos os casos menor do que a heterozigosidade esperada, indicando que há mais homozigotos nas populações que o esperado pelas proporções do E.H.W. (Tabela 10), embora estes valores não sejam significativos, conforme observado na análise do sistema de reprodução.

Comparando os níveis de diversidade genética aqui obtidos com os observados por Hamrick \& Godt (1990) para o número médio de alelos por locos $(2,19)$, a porcentagem de locos polimórficos $(64,7 \%)$ e heterozigosidade esperada $(0,177)$ em espécies arbóreas, verifica-se que E. ovata apresenta níveis bem superiores a estes. A baixa ocorrência de alelos raros e freqüências alélicas equilitariamente distribuídas, provavelmente, contribuíram para a 
alta diversidade. Outro fator que provavelmente contribuí para esta diversidade foi a alta densidade populacional apresentada pela espécie. Hamrick \& Murawski (1991) compararam a diversidade genética em espécies arbóreas tropicais comuns e raras e observaram a tendência das espécies comuns em apresentar maiores níveis de diversidade relativamente às espécies raras. A maior densidade de indivíduos pode permitir maior número de recombinações e múltiplas paternidades nas progênies, favorecendo ao aumento dos níveis de diversidade genética.

Tabela 10. Índices de diversidade genética intrapopulacional e relação $\hat{N}_{e} / n *$ em populações de E. ovata

\begin{tabular}{lccccccc}
\hline População & $n$ & $\hat{A}$ & $\hat{P}(\%)$ & $\hat{H}_{e}$ & $\hat{H}_{o}$ & $\hat{N}_{e}$ & $\hat{N}_{e} / n^{*}$ \\
\hline Adultos & & & & & & & \\
CAN & 45,4 & 2,14 & 85,7 & 0,402 & 0,390 & 55,3 & 0,97 \\
ITE & 38,6 & 2,14 & 85,7 & 0,426 & 0,345 & 49,5 & 0,84 \\
ITBA & 46,6 & 2,14 & 85,7 & 0,431 & 0,379 & 49,0 & 0,89 \\
Média & 43,5 & 2,14 & 85,7 & 0,420 & 0,371 & 51,0 & 0,89 \\
& & & & & & & \\
Progênies & & & & & & & - \\
CAN & 177 & 2,45 & 81,8 & 0,380 & 0,353 & - & - \\
ITE & 179 & 2,36 & 81,8 & 0,354 & 0,332 & - & - \\
Média & 178 & 2,41 & 81,8 & 0,367 & 0,343 & - & - \\
\hline
\end{tabular}

$n *$ - tamanho da amostra.

O tamanho efetivo de endogamia foi próximo ao número de indivíduos amostrados. A maior diferença foi observada na população explorada, com uma relação entre o tamanho efetivo e o número senso de 0,84 . Este resultado pode ser um indicativo dos efeitos das ações antrópicas ocorridas nesta área. O maior valor dessa relação foi observado na população natural, sendo esta de 0,97 . Tomando estes valores e considerando a alta densidade da 
espécie (comum) e o tamanho das áreas estudadas, quando combinada com as altas heterozigosidades, número médio de alelos por locos e porcentagem de locos polimórficos, pode-se afirmar que as populações estudadas têm alto potencial para a conservação genética in situ da espécie, bem como para a coleta de germoplasma visando sua conservação ex situ e coleta de sementes para a restauração de áreas degradadas.

\subsection{Estrutura genética espacial}

Os resultados das análises de estrutura espacial nas populações de E. ovata em Camarugipe e na explorada de Itaparica são apresentados na Tabela 11 e 12, mostrando as estimativas do Índice de Moran para cada alelo nas dez classes de distância estabelecidas. Uma representação gráfica do comportamento médio dos coeficientes de autocorrelação espacial está na Figura 5 e 6.

As estimativas de autocorrelação espacial, obtidas pela correlação de Bonferroni, demostrou que $11,5 \%$ dos valores totais estimados do $I$ de Moran foram significativos na população natural de Camarugipe, enquanto que na população explorada de Itaparica esta significância foi em 34,6\% dos casos. De modo geral, estes resultados apontam haver indícios de estruturação na distribuição genética espacial nestas populações em parte dos alelos analisados, tendo a população de Itaparica apresentado uma estruturação um pouco mais pronunciada em relação a de Camarugipe. Os resultados não foram consistentes para todos os alelos e locos analisados em ambos os locais. O alelo 1 do loco Skdh na população de Camarugipe e o alelo 1 da PGI-2 na população de Itaparica, foram os que apresentam maior evidência à autocorrelação.

A população de Camarugipe apresenta dois valores positivos e significativos na primeira (0 a 26 m) e segunda classe (26 a 51 m) de distância, um na sétima (154 a 180 m) e na nona classe (205 a 231 m), e três na oitava (180 a 205 m). Quatro classes desta população apresentam valores negativos e significativos, sendo esta ocorrência observada nas classes mais distantes. Observando o comportamento dos alelos nos locos analisados (Tabela 11) nota-se que existe tendência dos indivíduos da primeira classe de distância apresentarem 
correlação, podendo ser esta considerada fraca. De modo geral, vê-se uma tendência à aleatoriedade ao invés de agregação. Porém, os resultados médios obtidos para esta população demostraram uma tendência maior de os indivíduos localizados mais distantes apresentarem genótipos mais divergentes do que os mais próximos. Isto pode ser observado através do correlograma (Figura 5). Neste, nota-se que a classe de distância na qual passa pelo eixo horizontal ocorre num raio próximo de $50 \mathrm{~m}$, reforçando a afirmação de que há uma pequena agregação dos genótipos parecido nesta classe de menor amplitude de distância.

$\mathrm{Na}$ população de Itaparica, todas as classes de distância apresentam valores significativos. Valores significativos e positivos são observados na primeira classe de distância enquanto que valores negativos também significativos expressam-se nas classes de maior distância, apresentando as classes intermediárias uma tendência à aleatoriedade. Isto implica em haver nesta população, uma tendência predominante das árvores mais próximas apresentarem genótipos mais parecidos do que as árvores que se encontram mais distantes. $\mathrm{O}$ correlograma demostra haver agregação de genótipos parecidos não apenas quando se considera as classes menores de distância como também nas intermediárias.

$\mathrm{Na}$ análise de estrutura espacial dos genótipos em populações, autocorrelações significativas podem ocorrer em resposta a diferentes fatores, tanto seletivos como aleatórios (Sokal \& Oden, 1978). Os gradientes de variação da frequência alélica ao longo de uma distância geográfica ocorrem frequientemente em resposta à gradientes ambientais, podendo a ação aleatória da deriva provocar o isolamento pela distância, sem que haja envolvimento de qualquer fator seletivo no processo.

Em espécies alógamas, a presença de autocorrelação pode ser atribuída muitas vezes à seleção, ou à dispersão de sementes nas vizinhanças das matrizes. Linhart \& Grant (1996) citados por Perecin (2000), explicam que o arranjamento espacial dos genótipos em estruturação de famílias pode ser causado por alguns fatores ecológicos como a restrita dispersão do pólen e sementes. Estes autores comentam, ainda, que o fluxo gênico e a dispersão de sementes, contrariamente à sua natureza homogeneizadora, podem operar como uma fonte importante de heterogeneidade local em curtas distâncias. A existência de 
autocorrelação entre os indivíduos mais próximos e a detecção de cruzamentos entre parentes em E. ovata, pressupõe a presença de uma certa estruturação genética espacial nas populações estudadas.

Uma observação importante obtida nas áreas estudadas, é a notória presença de sementes germinadas próximas às árvores mães. Não é possível inferir sobre o sucesso de estabelecimento destas progênies no local, porém, sendo a espécie bastante comum, cerca de 200 indivíduos por hectare, desde plântula a adulto (Assis \& Picollo, 2000), e havendo na amostragem dos indivíduos adultos representantes de várias gerações, é provável que essa eficiência de estabelecimento seja alta.

Cruzamentos entre parentes foi detectado na análise do sistema de reprodução em ambas as populações estudadas, sendo esta maior na população de Itaparica. O índice de fixação nas árvores adultas também se apresentou maior nesta última população $(0,193)$. Estes fatos podem explicar a presença de uma certa estruturação genética espacial nas populações, com maior expressão desta na população de Itaparica.

Fatores históricos de interferências antrópicas causadoras de distúrbios ambientais, como a exploração desordenada, devem interferir sobre os padrões de distribuição genotípica na população, porém, não é possível afirmar que esta maior autocorrelação na distribuição espacial dos genótipos na população de Itaparica está associada intrinsecamente ao manejo voltado à extração de caules de E. ovata para a confecção de berimbau, já que esta é uma atividade que vem se desenvolvendo a não mais de que 13 anos. Sabe-se, porém, que a extração seletiva de madeira na área ocorreu em proporções consideráveis, sendo a espécie em questão bastante utilizada. Esta forma de intervenção na população pode estar associada ao padrão de estruturação apresentado pelos indivíduos adultos atualmente estabelecidos. 
Tabela 11. Coeficientes de autocorrelação espacial (Índice $I$ de Moran) obtidos nos 13 alelos de sete locos polimórficos, para 10 classes de distâncias na população de Camarugipe, em E. ovata

\begin{tabular}{llllllllllll}
\hline & & & & \multicolumn{7}{c}{ Limite de distância } \\
& 26 & 51 & 77 & 103 & 128 & 154 & 180 & 205 & 231 & 257 & \\
$\mathrm{~N}^{\text {o }}$ pares & 211 & 266 & 221 & 217 & 175 & 145 & 128 & 86 & 67 & 80 & Prob \\
\hline Pgi-11 & 0,01 & $0,11^{* *}$ & $-0,10$ & $-0,09$ & $-0,12$ & $-0,04$ & $-0,07$ & $0,23^{* *}$ & $-0,00$ & $-0,03$ & 0,051 \\
Pgi-12 & $-0,01$ & $-0,09$ & 0,02 & $-0,07$ & 0,03 & 0,09 & $-0,12$ & $0,20^{*}$ & $-0,27 * *$ & 0,10 & 0,097 \\
Pgi-13 & 0,03 & $-0,05$ & 0,03 & 0,05 & $-0,07$ & $-0,09$ & 0,08 & $-0,12$ & $-0,01$ & $-0,12$ & 1,000 \\
Pgi-21 & 0,04 & $-0,10$ & $-0,04$ & $-0,01$ & 0,03 & $-0,07$ & $-0,03$ & $0,18^{*}$ & $-0,03$ & $-0,03$ & 0,211 \\
Pgi-22 & $0,14 * *$ & $-0,10$ & $-0,08$ & 0,00 & $-0,00$ & $-0,18^{*}$ & $-0,05$ & $0,26^{* *}$ & 0,00 & $-0,02$ & 0,021 \\
Pgi-23 & 0,04 & 0,05 & 0,03 & 0,05 & $-0,02$ & $-0,14^{*}$ & $-0,07$ & $-0,14$ & $-0,18$ & $-0,14$ & 0,418 \\
Po-11 & $-0,04$ & $-0,04$ & $-0,05$ & 0,02 & 0,02 & $-0,04$ & $-0,04$ & 0,07 & 0,01 & $-0,03$ & 1,000 \\
Acp-11 & $-0,03$ & $-0,04$ & $-0,05$ & 0,01 & $-0,02$ & 0,01 & $-0,01$ & $-0,02$ & $-0,01$ & 0,04 & 1,000 \\
Dia-11 & $-0,03$ & 0,00 & $-0,03$ & $-0,05$ & $-0,08$ & 0,03 & 0,06 & $-0,01$ & 0,06 & $-0,10$ & 1,000 \\
Skdh-11 & $0,12^{*}$ & $0,12^{* *}$ & $-0,02$ & $-0,08$ & $-0,03$ & $-0,04$ & $0,13^{*}$ & $-0,18^{*}$ & $-0,16$ & $-0,57 * *$ & 0,000 \\
6Pgdh-11 & $-0,03$ & $-0,02$ & 0,00 & 0,00 & 0,06 & $-0,16^{*}$ & 0,03 & $-0,09$ & $0,16^{*}$ & $-0,13$ & 0,334 \\
6Pgdh-12 & 0,08 & $-0,06$ & $-0,05$ & $-0,00$ & 0,09 & $-0,04$ & $-0,19^{*}$ & $-0,03$ & $-0,01$ & 0,01 & 0,183 \\
6Pgdh-13 & $-0,07$ & 0,00 & $-0,01$ & $-0,06$ & $-0,06$ & 0,10 & $-0,05$ & 0,00 & 0,03 & 0,01 & 0,697 \\
& & & & & & & & & & &
\end{tabular}

$P$ : Significância total do correlograma (aproximação de Bomferroni); **: $\mathrm{P}<0,01 ; * \mathrm{P}<0,05$.

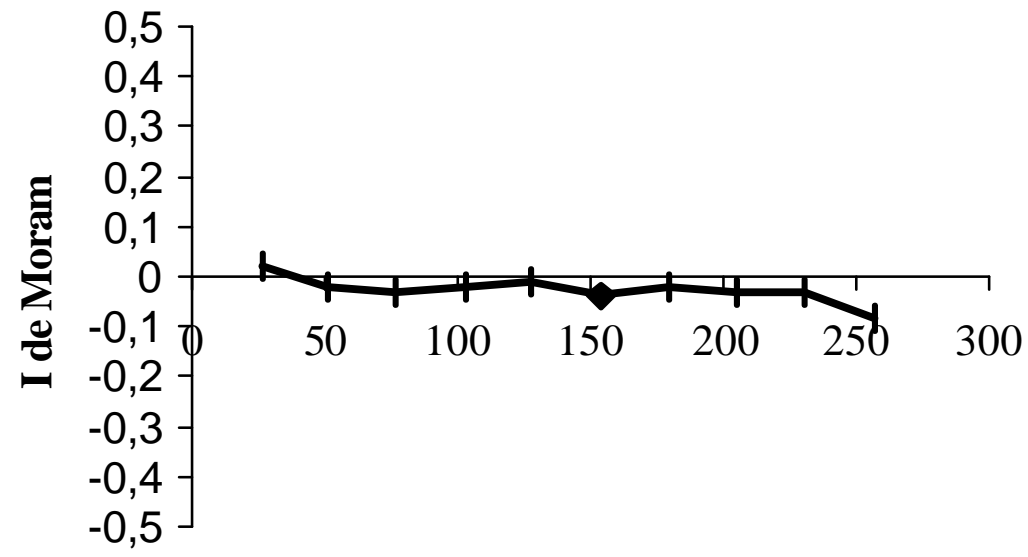

Classe de distâncias (m)

Figura 5. Correlograma para o índice $I$ de Moran para o método do vizinho mais próximo por classes de distância na população Camarugipe, em E. ovata 
Tabela 12. Coeficientes de autocorrelação espacial (Índice $I$ de Moran), obtidos nos 13 alelos de sete locos polimórficos, para 10 classes de distâncias na população de Itaparica, em E. ovata

\begin{tabular}{|c|c|c|c|c|c|c|c|c|c|c|c|}
\hline \multirow[b]{3}{*}{$\mathrm{N}^{\mathrm{o}}$ pares } & \multicolumn{11}{|c|}{ Limite de distância } \\
\hline & 25 & 50 & 75 & 100 & 125 & 150 & 175 & 200 & 225 & 250 & \\
\hline & 303 & 266 & 218 & 123 & 71 & 101 & 107 & 104 & 128 & 64 & \\
\hline Pgi11 & $0,07 * *$ & 0,01 & 0,03 & 0,00 & $-0,02$ & 0,02 & $-0,12^{*}$ & $-0,10$ & $-0,11^{*}$ & $\begin{array}{l}- \\
0,32 * *\end{array}$ & 0,001 \\
\hline Pgi12 & $0,34 * *$ & $0,20 * *$ & 0,03 & 0,07 & $-0,01$ & $-0,09$ & $-0,06$ & $\begin{array}{l}- \\
0,53 * *\end{array}$ & $\begin{array}{l}- \\
0,67 * *\end{array}$ & $0,62 * *$ & 0,000 \\
\hline Pgi13 & $0,09^{* *}$ & $-0,02$ & $0,10^{*}$ & $-0,11$ & $-0,07$ & $\begin{array}{l}- \\
0,23 * *\end{array}$ & $-0,07$ & $0,24 * *$ & $-0,03$ & 0,10 & 0,046 \\
\hline Pgi21 & $0,48 * *$ & $0,23 * *$ & $0,16^{* *}$ & $0,14^{*}$ & $\begin{array}{l}- \\
0,31 * *\end{array}$ & $\begin{array}{l}- \\
0,33 * *\end{array}$ & $\begin{array}{l}- \\
0,32 * *\end{array}$ & $\begin{array}{l}- \\
0,71 * *\end{array}$ & $\begin{array}{l}- \\
0,71 * *\end{array}$ & $\begin{array}{l}- \\
0,54 * *\end{array}$ & 0,000 \\
\hline Pgi22 & $0,11 * *$ & $-0,00$ & $-0,01$ & 0,11 & 0,03 & $-0,07$ & $-0,03$ & 0,04 & $\begin{array}{l}- \\
0,37 * *\end{array}$ & $\begin{array}{l}- \\
0,31 * *\end{array}$ & 0,000 \\
\hline Pgi23 & $-0,05$ & $-0,04$ & 0,06 & $-0,06$ & $-0,01$ & $-0,10$ & 0,07 & $-0,09$ & 0,09 & $-0,10$ & 0,655 \\
\hline Po11 & $-0,03$ & 0,03 & $-0,07$ & 0,04 & 0,01 & $-0,08$ & 0,07 & 0,12 & $-0,10$ & $-0,23^{*}$ & 0,258 \\
\hline Acp11 & $0,06^{*}$ & $-0,04$ & 0,02 & $-0,01$ & $-0,05$ & 0,01 & $-0,15$ & $-0,21^{*}$ & $-0,01$ & 0,00 & 0,159 \\
\hline Dia11 & $0,09 *$ & $-0,13^{*}$ & $-\overline{0,16 * *}$ & 0,08 & $0,19 *$ & $-0,11$ & 0,10 & $0,18^{*}$ & $-0,19^{*}$ & $-0,07$ & 0,097 \\
\hline Skdh11 & $-0,08$ & 0,00 & $-0,06$ & 0,07 & 0,01 & $-0,02$ & 0,03 & $-0,06$ & $-0,06$ & 0,15 & 0,599 \\
\hline 6Pgdh11 & 0,05 & $0,07^{*}$ & $-0,03$ & 0,04 & $-0,16$ & $-0,14$ & $-0,19 *$ & 0,03 & $-0,04$ & $-0,19$ & 0,236 \\
\hline 6Pgdh12 & $0,06^{*}$ & $-0,04$ & $-0,14 *$ & $-0,10$ & $-0,24^{*}$ & 0,10 & 0,10 & $-0,00$ & $0,17 * *$ & $-0,27^{*}$ & 0,084 \\
\hline 6Pgdh13 & $0,23^{* *} *$ & $-0,13^{*}$ & $0,33 * *$ & 0,06 & 0,06 & $-0,11$ & 0,05 & 0,09 & $-0,05$ & 0,02 & 0,000 \\
\hline Média & 0,11 & 0,01 & $-0,03$ & 0,03 & $-0,04$ & $-0,09$ & $-0,04$ & $-0,11$ & $-0,16$ & $-0,18$ & \\
\hline
\end{tabular}

$P$ : Significância total do correlograma (aproximação de Bomferroni); ${ }^{* *}: \mathrm{P}<0,01 ; * \mathrm{P}<0,05$.

Figura 6 - Correlograma para o índice $I$ de Moran para o método do vizinho mais próximo

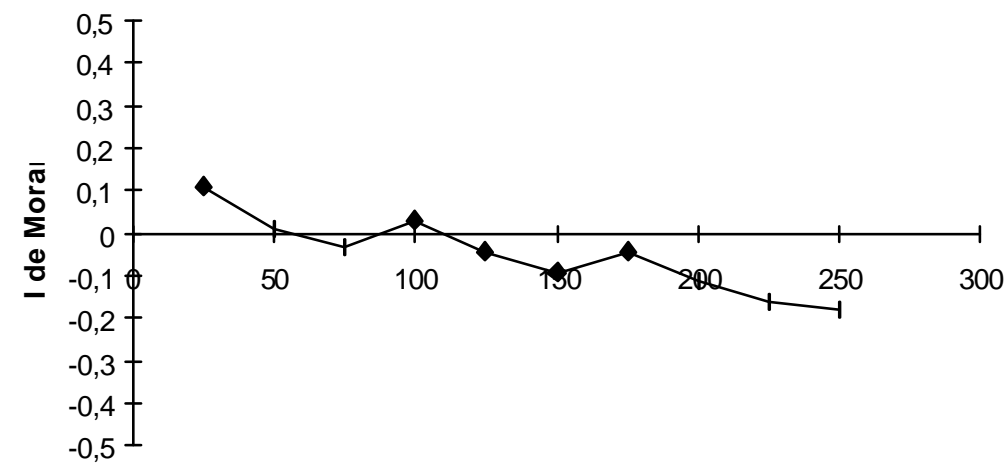

Classes de distâncias (m)

por classes de distância na população explorada de Itaparica, em E. ovata 
O reconhecimento da existência de um certo nível de estruturação genotípica nas populações da espécie, auxilia no estabelecimento de medidas de conservação genética, indicando formas de maximizar a diversidade genética na coleta de sementes para conservação ex situ, bem como inferir nos tamanhos mínimos de área para conservação in situ. Por exemplo, com base nos presentes resultados, a coleta de sementes não deve ser realizada em árvores localizadas dentro de distâncias inferiores a 50 m, para evitar amostrar sementes de árvores parentes, o que reduziria o tamanho efetivo da amostra. Além disso, notada a presença de maior agregação dos genótipo na população de Itaparica, o que possibilita afirmar que efeitos antrópicos podem ser geradores de estruturação, quando então na realização de práticas de manejo em áreas naturais, deve-se considerar essa característica de estruturação, devendo as extrações de indivíduos da espécie ser realizada de modo que reduzam o agrupamento de árvores aparentadas.

\subsection{Subsídios ao manejo e à conservação genética de populações naturais de $E$. ovata}

Com base nos conhecimentos ecológico e genético da espécie, a proposição de recomendações gerais à prática do manejo de E.ovata em área naturais torna-se possível, sendo esta importante como forma de subsidiar sua extração adquada por populações locais, bem como para determinar o uso de estratégias de conservação genética da espécie.

A capacidade de rebrota é de fundamental importância à sustentabilidade do manejo da espécie. A rebrota pode ser considerada uma estratégia evolutiva para a sobrevivência do indivíduo em caso de danos físicos como, por exemplo, a quebra por ventos, capacidade esta observada em diversas espécies. A rebrota é uma característica relevante à conservação da espécie, pois, teoricamente, os genótipos dos indivíduos que rebrotam mantêm-se nas populações. Sabe-se, porém, que em algumas espécies de Eucalyptus que apresentam rebrota após corte, esta condição ocorre em até cerca de 5 ciclos de corte, vindo a cepa a perder seu vigor de regeneração posteriormente, levando assim o indivíduo à morte. É possível que a mesma condição venha a ocorrer em E. ovata, devendo o manejador conhecer o número de cortes sucessivos que a espécie suporta, com o intuito de não excluir indivíduos da população. 
Por outro lado, deve-se considerar que alguns caules de rebrota deixam de apresentar características desejáveis para a confecção do instrumento, motivo pelo qual o manejador deixa de extraí-los, vindo a ser este indivíduo recrutado para a classe superior de diâmetro. Esses indivíduos, junto aos novos que se estabeleceram na área via sementes, passaram a compor um agrupamento que irá representar as futuras classes de adultos. Assim, o fato da espécie apresentar rebrota de cepas após seu corte faz com que a intervenção numa determinada área, apenas retarde o recrutamento desses indivíduos ao conjunto de adultos sexualmente ativos na população.

Outro fato importante a ser considerado é que alguns locais da floresta estudada são mantidas semintervenção de manejo, devido à dificuldade de retirada do material coletado em algumas destas áreas. Essss, assim, caracterizam pontos cruciais para conservação da espécie na área, servindo como fonte de propágulos na recolonização das áreas adjacentes à exploradas.

As estimativas dos parâmetros analisados do sistema reprodutivo e estrutura genética das populações natural e explorados de E. ovata abordadas neste estudo, de modo geral, demostram que o manejo tradicional da espécie nesta área, caracterizado pela extração de caules novos com a finalidade de obtenção de matéria-prima para a confecção do arco de berimbau, não apresentam, até o momento, diferenças significativas que possam estar associadas à influência desta atividade de exploração. $\mathrm{O}$ reconhe cimento da forma de atuação dos extratores e da dinâmica de recrutamento da espécie na área manejada, obtidos através do levantamento de informações etnobotânicas junto aos extratores locais, apontavam, de certa forma, para a obtenção desses resultados.

Pode-se considerar que a extração da espécie na área estudada, caracterizada por ser um contínuo florestal bastante extenso, apresenta peculiaridades singulares. A visitação das áreas pelos mesmos extratores, os quais possuem bom conhecimento da dinâmica desta floresta, faz com que haja boas perspectivas à conservação genética da espécie, ao menos, a curto e médio prazo. Esta atividade tradicional de extração deve ser reconhecida como uma condição ideal, caso não se altere o método de extração.

Não é esta, porém, a configuração apresentada na grande maioria das áreas utilizadas 
para a extração de biribas nos arredores de Salvador, onde a extração é comumente realizada em pequenos fragmentos, os quais se apresentam em níveis de conservação, muitas vezes, inferiores ao caso estudado, e apresentam intensidade de extração diferenciadas. É reconhecido que a alta intensidade de manejo nas populações, normalmente, reduz o número de indivíduos recrutados às classes superiores de diâmetro. Gentry (1978), porém, aponta que diferentes formas de distúrbios provocados por ações antrópicas podem determinar influências diferenciadas sobre as populações de plantas, muitas vezes favorecendo o aumento de densidade de certas espécies. Esta condição é observada na espécie E ovata, a qual apresenta expressiva regeneração assexuada nas áreas sob extração intensiva, conforme apresentado por Cunha et al. (1996). No estudo de áreas manejadas da espécie realizada por estes autores, foram encontradas elevadas quantidades de caules na classe inferior (2,5 a 5 $\mathrm{cm}$ ), o que de certa forma é bastante favorável para o manejo de biribas, porém, deve-se levar em conta que a grande maioria destes caules eram constituídos de rebrotas de um mesmo indivíduo.

Os brotamentos na espécie ocorrem tanto nas porções aéreas remanescentes após o corte, como da porção caulinar subterrânea que se apresenta disposta horizontalmente. Assis \& Picollo (2000), em estudo da populações da espécie sob exploração, observaram que apenas $15,7 \%$ dos indivíduos amostrados eram constituídos de um único caule, tendo praticamente todas os caules cortados apresentado brotações, em média, cinco brotações por indivíduo, constituindo touceiras. Este fenômeno de rebrota faz com que o número de caules presentes numa determinada área seja diferente do número efetivo de indivíduos, tendo na realidade uma grande proporção de caules que são de uma mesma árvore, o que implica em um menor tamanho efetivo populacional. Dessa forma, os caules que irão constituir as classes dos jovens na distribuição diamétrica em "J" invertido, apresentada pela espécie, possuirão a mesma composição genética. Em outros termos, não estará ocorrendo o recrutamento de novos indivíduos provindo de recombinação gênica.

Mesmo que indivíduos de menor diâmetro venham a participar deste processo de reprodução, a quantidade de sementes disponibilizadas por estes indivíduos será bastante inferior. 
Cunha et al. (1996) observaram também a inexistência de regeneração via sementes, fato este atribuído ao baixo número de indivíduos adultos na área por eles estudada. Estas condições não constituem boas perspectivas àmanutenção genética da espécie. A participação de poucos indivíduos no fenômeno de reprodução, dependendo da distribuição espacial destes, aumenta a possibilidade de cruzamentos entre aparentados ou a ocorrência de maior taxa de autofecundação pelo isolamento de indivíduos, tendo como consequiência o aumento na endogamia, levando à diminuição da diversidade genética. Esta perda de diversidade deve refletir diretamente na sustentabilidade da população alvo de manejo. Seria interessante que a manutenção dos estoques, ou a manutenção de grande número de indivíduos das classes de menor diâmetro, fosse composta não só de caules de rebrotas mas, principalmente, por indivíduos jovens provindos de regeneração via sementes, minimizando os problemas relacionados aos processos geradores de endogamia populacional.

Tendo sido observado que a espécie apresenta uma certa agregação espacial dos genótipos, e sendo os indivíduos mais próximos aparentados entre si, seria viável que no manejo de uma área fossem extraídos os caules próximos às árvores matrizes, reduzindo a estruturação familiar apresentada pela espécie. A espécie possui bom potencial ao manejo de produto madereiro devido sua distribuição diamétrica, conforme estudo realizado por Araújo et al. (1993) - citado por Cunha (1996). A mesma recomendação, de retirada de indivíduos espacialmente próximos, seria dada caso fosse o manejo voltado à obtenção de produto madereiro, prática esta não recomendada, devido à baixa representatividade dos remanescentes florestais da Mata Atlântica existente atualmente.

Com base nas informações levantadas, para que o manejo da espécie em populações naturais seja considerado viável e adequado, deve ser considerado não apenas o número de indivíduos dentro população mas também a conformação da distribuição espacial destes na área.

Considerando a relação $\hat{N}_{e} / n$ média observada nas populações estudadas de 0,89 , pode ser um equivoco considerar que uma área com uma população de 57 indivíduos adultos reprodutivos seja suficiente à manutenção genética da espécie a curto prazo, e 560 indivíduos para a manutenção a longo prazo. Deve-se pensar que, tendo as populações revelado uma 
certa agregação de genótipos em um raio de aproximadamente 50m, a simples determinação da existência de 57 indivíduos adultos dentro de uma população não garantiria a capacidade de manutenção do nível de diversidade genética nas gerações subsequentes, vindo possivelmente a ocorrer erosão genética nestas populações. Mais coerente seria, do ponto de vista da conservação, considerar a área de abrangência de um "agrupamento gênico" (conjunto de indivíduos próximos aparentados) de uma área, sendo este de aproximadamente 0,785 ha. Deve-se considerar que, quanto mais destes agrupamentos em uma população, menos ameaçadas estariam estas às perdas de sua diversidade genética.Visando a conservação a longo prazo da espécie, a população deve então ser consideravelmente maior.

Como forma de apontar indicadores do potencial de manejo e conservação em áreas florestais, um raciocínio possível de se desenvolver seria o de que uma área com aproximadamente 400 hectare e com adensamento populacional de ao menos 20 indivíduos por hectare, seja sufuciente para conter 500 desses agrupamentos gênicos, servindo para a conservação a longo prazo da espécie. Populações de cerca de 40 ha, seriam, então, suficientes à conservação a curto prazo. Estas estimativas não devem ser tomadas como números fixos que podem ser extrapolados a todas as condições, por haverem variáveis como, por exemplo, diferentes densidades demográficas e históricos de perturbação, que influenciam diretamente nesses valores. Porém, estas servem como um indicativo ao reconhecimento de populações viáveis ao manejo. A proposição de um plano de manejo da espécie deve ser realizado perante a determinação e acompanhamento da curva de distribuição diamétrica balanceada, para se quantificar a intensidade possível de manejo na área, no tempo e espaço.

Considerando a potencialidade da espécie nos processo de restauração/recuperação florestal, recomenda-se a coleta de sementes em árvores espaçadas por pelo menos $50 \mathrm{~m}$. Esta recomendação aplica-se também na formação de bancos de germoplasma para a conservação "ex-situ". Deve-se salientar que para estas finalidades, a coleta deve ser realizada de aproximadamente 23 árvores, para que se garanta um tamanho efetivo de 50. A coleta em matrizes próximas não assegura a obtenção deste tamanho efetivo, já que este banco estaria sob influência do efeito da endogamia, ocasionada devido ao sistema reprodutivo na 
população. E, ainda, o tamanho efetivo só é assegurado caso a coleta seja realizada em áreas com as mesmas características apresentadas pelas áreas de estudo, ou seja, áreas com grande número de indivíduos adultos na população, conforme comentado anteriormente. 


\section{CONCLUSÕES}

1. A reprodução em E. ovata ocorre predominantemente por cruzamentos.

2. Os cruzamentos nas populações de Eschweilera ovata não ocorrem de forma aleatória, podendo suas progênies serem constituídas de misturas de irmãos de autofecundação, irmãos-completos e meios-irmãos.

3. Para a coleta de sementes em populações de E. ovata para fins de conservação ex situ e recuperação de áreas degradadas são necessárias sementes de pelo menos 23 árvores para reter o tamanho efetivo de 50. Se o tamanho efetivo requerido for maior, este número deverá ser ampliado.

4. As árvores de E. ovata dentro das populações estudadas encontram-se espacialmente estruturadas, sendo que quanto mais próximos os indivíduos maior é probabilidade deles serem parentes.

5. As populações estudadas da espécie apresentam altos níveis de diversidade genética dentro e baixa entre populações. Os níveis de diversidade genética dentro são superiores aos apresentados pela maioria das espécies arbóreas tropicais estudadas.

6. O estudo do sistema reprodutivo e estrutura genética na população manejada de E. ovata, demostraram que o manejo tradicional da espécie na área estudada, caracterizado pela extração de caules novos com a finalidade de obtenção de matéria-prima para a confecção do arco de berimbau, não apresentaram diferenças significativas dos parâmetros analisados em relação às populações não exploradas, que possam ser atribuídas a esta atividade de exploração, não devendo esse resultado ser extrapolado para toda e qualquer área sob regime de exploração. 


\section{REFERÊNCIAS BIBLIOGRÁFICAS}

ALFENAS, A. C.; PETERS, I.; Brune, W.; Passsador, G.C. Eletroforese de proteínas e fungos em essências florestais. Viçosa: UFV, 1991. 242p.

ALFENAS, S.A. Eletroforese de isoenzimas e proteínas afins: fundamentos e aplicações em plantas e microrganismos.Viçosa: UFV, 1998. 574 p.

ALVES, R. M. Caracterização genética de populações de cupuaçuzeiro, Theobroma grandiflorum (Willd. ex. Spreng.) Schum., por marcadores microssatélites e descritores botânico-agronômicos. Piracicaba, 2002. 146p. Tese (Doutorado). Centro de Energia Nuclear na Agricultura, Universidade de São Paulo.

ALVES, R.M.; SEBBENN, A.M. FIGUEIRA, A. Mating system in natural population of Theobroma grandiflorum (Willd ex Spreng) Shumm genetics and molecular, Biology, v. 79, n.2, p. 20-31. 2003.

ARNOLD, J. E. M.; PÉREZ, M. R. Can non-timber forest products match tropical forest conservation and development objectives? Ecological Economics, v.39, p. 437-447, 2001.

ASSIS, M. A.; PICCOLO, P. R. Estruturas populacionais de Eschwelera ovata (Cambess.) Miers (Lecythidaceae) submetidas à ação de cortes seletivos. IN: SIMPÓSIO DE ECOSSISTEMAS BRASILEIROS, 5., Vitória, ES, 2000. Resumos. Vitória: Ed. ACIESP, 2000. p.152.

BALÉE, W. The culture of Amazonian forests. Advances in Economic Botany, v.7, p.1-21, 1989.

BARRET, S.C.H.; KOHN, J.R. Genetic and evolutionary consequences of small population size in plants: implications for conservation. In: FALK, D.A.; HOLSINGER, K.E., (Ed.). Genetics and conservation of rare plants. Oxford: Oxford University Press, 1991. p. 3-30. 
BAWA, K.S. Breeding systems of tree species for a lowland tropical community. Evolution v. 28, p. 85-92, 1974.

BAWA, K.S.; KRUGMAN, S.L. Reproductive biology and genetics of tropical trees in relation to conservation and management. In: GÓMEZ-POMPA, A.; WHITMORE, T.C.; HADLEY, M. (Ed.). Rain forest regenration and management. Paris: The Parthenon Publishing Group, 1994. 457p. (Man and the biosphere series, v.6)

BAWA, K.S.; PERRY, D.R.; BEACH, J.H. Reproductive biology of tropical lowland rain forest trees. 1. Sexual systems and incompatibility mechanisms. American Journal of Botany, v. 72, n. 3, p. 331-345, 1985.

BAZZAZ, F. A. E PICKETT, S. T. A. Physiological ecology of tropical sucession: a comparative. Annual Review of Ecology and Systematics, v. 11, p. 287-310, 1980.

BEGOSSI, A., HANAZAKI, N., PERONI, N. Knowledge and use of biodiversity in Brazilian hot spots. Environment, Development and Sustainability, v. 2, p.177-193, 2001.

BONATES, L. C. M.;ROCHA, J. S.; ABREU, F. J.; SILVA, A. J. P. Etnobotânica do Berimbau. I - Qualidade Instrumental. In: CONGRESSO NACIONAL DE BOTÂNICA, Salvador - BA, 1998. Resumos Salvador, 1998. p. 264.

BROOKFIELD, H.; PADOCH, C. Appreciating agrodiversity: a look at the dynamism and diversity of indigenous farming practices. Environment, v.36, n.5, p.6-45, 1994.

BUDOWSKI, G. distribuion of tropical american rain forest species in the light of sucessional progress. Turialba, v.15, p. 40-42, 1965.

CABALLERO, A. Developments in the prediction of effective population size. Heredity, v. 73, p 657-679, 1994.

CARVAlHO, M. G.;VELANDIA, R. J.; OLIVEIRA, L. F. E.; BEZERRA, F. B. Triterpenos isolados de Eschweilera longipes Miers ( Lecythidaceae). Pharmaceutical Biology, v. 37, n. 3, p. 208-215, 1999.

CHELIAK, W.M.; PITTEL, J.A. Techniques for starch gel eletrophoresis of enzymes from forest tree species. Information Report, v. 42, p. 1-49, 1984. 
CLAYTON, J.; TRETIAK, D. Amine-citrate buffers for $\mathrm{pH}$ control in starch gel electrophoresis. Journal Fisheries Research Board Canadian, v. 29, p. 11691172, 1972.

CLEGG, M.T. Measuring plant mating systems. Bioscience, v. 30, n. 12, p. 814-818, 1980.

COCKERHAM, C.C. Variance of gene frequencies. Evolution, n. 23, p. 72-84, 1969.

COCKERHAM, C.C.; WEIR, B.S. Covariances of relatives stemming a population undegoing mixed self and random mating. Biometrics, v. 40, p. 157-164, 1984.

CONSERVATION INTERNATIONAL. http///www.conservation. org.br/alianca/bioma/ htm. (2 sep. 2003)

CUNHA, R. P. P.; ASSIS, M. A.; PICCOLO, P. R.; CHIMICHAQUE, E. R.; SILVA, A J. P. Estudos dos fragmentos da mata atlântica e seu uso para fins comerciais e folclóricos na grande Salvador - Bahia, Salvador: FUNAMA, 1996. 1v. (Relatório Técnico, FUNAMA)

CUNNINGHAM, A.B. Applied ethnobotany: people, wild plant use \& conservation. Earthscan, London: WWF;UNESCO; Royal Botanic Gardens Kew, 2001. 300p. (People and plants conservation manual)

DEAN, W. A ferro e fogo: a história e a devastação da mata atlântica brasileira. São Paulo: Companhia das Letras, 1996. 484 p.

DENSLOW, J. S. Gap partioning among tropical rain forest trees. Biotropica, v. 12, p. $47-55.1980$.

DIEGUES, A. C.; VIANA, V. M (Org.). Alternativas de manejo sustentável de recursos naturais do vale do ribeira/sp - mata atlântica. São Paulo, NUPAUB/USP, 2000. 273 p.

EL-KASSABY, Y.A.; SZIKLAI, O. Effect of sample size on the precision of the estimate of allozyme frequencies in a natural stand of Douglas-Fir. Egyptian Journal of Genetics and Citology, v. 24, p. 345-360, 1983. 
ELLEN, R. Models of subsistence and ethnobiological knowledge: between extraction and cultivation in southeast Asia. IN: MEDLIN, D. L.; ATRAN, S. (Ed.). Folkbiology, Cambridge: Massachussets Institute of Technology, 1999. 504p.

ESTRADA, A.; FLEMING, T.H. Frugivores and seed dispersal. The Hague. W. JUNK, 1986. 346 p.

FORGET, P. M. Seed removal and seed fate in Gustavia superba (Lecythidaceae). Biotropica, v. 24, p. 408-414, 1992.

FRANKEL, O.H.; SOULÉ, M.S. Conservation and evolution. Cambridge: Cambridge University Press, 1981. 327 p.

FUCHS, E.J.; LOBO, J.A.; QUESADA, M. Effects of forest fragmentation and flowering phenology on the reproductive success and mating patterns of the tropical dry forest tree Pachira quinata. Conservation Biology, v. 17, n. 1, p. 149-157, 2003.

FUTUYMA, D.J. Biologia evolutiva. Ribeirão Preto: SBG, 1992. 646 p.

GALVÃO,A.P.M.; MEDEIROS,A.C.S. Restauração da Mata Atlântica em áreas de sua primitiva ocorrência natura 1. Colombo: EMBRAPA, 2002. 133p.

GANDARA, F. B. Diversidade genética, taxa de cruzamento e estrutura espacial dos génotipos em uma população de Cedrela fissilis Vell. ( Meliacea). Piraciciaba,1996. 83p. Dissertação (Mestrado) - Escola Superior deAgricultura “Luiz de Querioz”, Universidade de São Paulo.

GANDARA,F.B.; KAGEYAMA,P.Y. Indicadores de sustentabilidade de florestas naturais. Série Técnica IPEF, v.12, n.31, p.79-84, 1998.

GRENTY, A. H. Diversidade e regeneração da capoeira do INPA, com referência especial as bignoniaceae. Acta Amazonica v. 8, p. 67-70, 1978.

GÓMEZ-POMPA, A. Possible papel la vegetación secundaria de la flora tropical. Biotropica, v. 3, p. 125-135,1971.

HAMRICK, J. L. Isozymes and analyses of genetic structure of plant populations. In SOLTIS, D.; SOLTIS, P. (Ed.). Isozymes in Plant Biology. Portland Oregon: Discorides Press, 1989. p. 87-105. 
HAMRICK, J. L. Isozymes and analyses of genetic structure of plant populations. In: SOLTIS, D; SOLTIS, P. (Ed.). Isozymes in Plant Biology, Portland Oregon: Discorides Press, 1989.p. 87-105.

HAMRICK, J. L.;M. J. GODT. Allozyme diversity in plant species In: BROWN, A. H. D.; M. T. CLEGG, A. L.; KAHLER; WEIR, B. S. (Ed.). Plant population genetics, breeding and germplasm resources, Sunderland, Mass: Sinauer, 1989. p. 43-63.

HAMRICK, J.L. The distribution of genetic variation within and among natural plant population. In: SCHONE-WALD-COX, C.M.; CHAMBERS, S.H.; MacBYDE, B.; THOMAS, L. Genetics and conservation. Menlo Park: Benjamin Cummings, 1983. p. 335-348.

HAMRICK, J.L.; LOVELESS, M.D. The influence of seed dispersal mechanisms on the genetic structure of plant populations. In: ESTRADA, A.; FLEMING, T.H. (Ed.). Frugivores and seed dispersal. Athens: Junk Publishers, 1986. cap. 17, p. 124-145.

HIGUSHI, N.; HUMMEL A. C. Desenvolvimento sustentável: a experiência do setor madereiro. In: HIGUCHI, N. (Coord). BIONTE: Biomassa e Nutrientes. Manaus: INPA, 1997. p. 153-166.

HOEBEE, S.E.; YOUNG, A.G. Low neighbourhood size and hig interpopulation differentiation in the endangered shrub Grevillea iaspicula McGill (Proteacea). Heredity, v. 88, p. 489-496, 2001.

HUBBELL. S . P.; Foster, R. B. Commonness and rarityin a neotropical forest: implication for tropical tree conservation. In: SOULÉ, M. E. (Ed.). Conservation biology: science of sarcity and diversity, Massachusettes: Sinauer, 1986. p. 205-231.

KAGEYAMA, P. K.; GANDARA, F. B. Recuperação de áreas degradadas. In: RODRIGUES, R. R. ( Ed.).Matas ciliares: conservação e recuperação, São Paulo: Edusp, 2000. p. 249-269.

KAGEYAMA, P. K.; LEPSCH-CUNHA, N. M. Singularidade da biodiversidade nos trópicos. In: GARAY, I.; DIAS, B. F. S. ( Ed.). Conservação da biodiversidade em ecossistemas tropicais, Petrópolis: Editora Vozes, 2001. p. 199-214. 
KAGEYAMA, P. K. Uso e conservação de florestas tropicais: qual paradigma? In: SIMPÓSIO DE ECOSSISTEMAS BRASILIEIROS: Conservação, 5., Vitória - ES, 2000. Anais São Paulo: ACIESP, 2000. p.72-82.

KAGEYAMA, P. K.; SANTARELLI, E.; GANDARA, F. B.; GONÇALVES, J. C.; SIMIOVATO, J. L.; ANTIQUEIRA, L. R.; GERES, W.L. Restauração de áreas degradadas modelos de consorciação de alta densidade. In: SIMPÓSIO NACIONAL SOBRE RECUPERAÇÃO DE ÁREAS DEGRADADAS, Foz do Iguaçu, 1994. Anais Curitiba: FUPEF, 1994. p. 569-576.

KAGEYAMA, P. K.;GANDARA, F. B.; SOUZA, L. M. I. Conseqüências genéticas da fragmentação sobre populações de espécies arbóreas. Instituto de Pesquisas e Estudos Florestais, v. 12, n. 32, p. 65-70, 1998.

KAGEYAMA, P.Y.; GANDARA, F. B.; VENCOVSKY, R. Conservação in situ de espécies arbóreas nativas. ln: NASS, L.L.; VALOIS, A. C. C.; IVELO, I. S.; VALADARES-INGLIS, M.C. Recursos genéticos e melhoramento. Rondonópolis: Fundação MT, 2001. p. 149-159.

KNUDSEN, J. T.; MORI, S. A. Floral scents and pollination in neotropical Lecythidaceae. Biotropica, v. 28, n. 1, p. 42-60, 1996.

LEWIS, P.0.; ZAYKIN, D. GDA - Genetic date analysis: version 1.0(d12) for Windows. Albuquerque: The University of New Mexico, 1999. 39 p.

LINDGREN, D.; GEA, L.; JEFFERSON, P. Loss of genetic diversity by status number. Silvae Genetica. v. 45. p. 52-59, 1996.

LINDGREN, D.; MULLIN, T.J. Balancing gain and relatedness in selection. Silvae Genetica, v. 46, n. 2/3, p. 124-129, 1997.

LORENZI, H.. Árvores brasileiras: manual de identificação e cultivo de plantas arbóreas nativas do Brasil. Nova Odessa: Plantarum, 1998. v.2.

LOVELESS, M.D.; HAMRICK, J.L. Ecological determinants of genetic structure in plant populations. Annual Review of Ecology and Systematics, v. 15, p. 65-95, 1984. 
MAINIERI, C.; CHIMELO, J.P. Fichas de características das madeiras brasileiras. SãoPaulo: Instituto de Pesquisas Tecnológicas, 1989. 432p.

MARTIN, G. J. Ethnobotany: A Methods Manual. London: Chapman \& Hall, 1995. $268 p$.

MARTÍNEZ-RAMOS, M. Claros, ciclos vitales de los árboles tropicales y regeneracíon natual de las selvas altas perenifólias. In: GOMES-POMPA, A.; DEL AMO, S. Investigationes sobre la regeneracón de selvas altas em veracruz. México: Alhambra Mexicana, 1985. p. 191-239.

MENEZES, B. Berimbau Sim ? Berimbau Não? A TARDE, Salvador, Caderno 2, p. $08,1996$.

MITTON, J.B. The dynamic mating systems of conifers. In 'Population genetics of forest trees. In: INTERNATIONAL SYMPOSIUM ON POPULATION GENETICS OF FOREST TREES. ADAMS, W.T.; STRAUSS, S.H.; COPES, D.L.; GRIFFIN; A.R. (Ed.). Dordrecht, 1992. Proceeding Dordrecht: KLUWER VERLAG, 1992. p. 197-216.

MINISTÉRIO DO MEIO AMBIENTE, Primeiro relatório nacional para a convenção sobre diversidade biológica - Brasil, Brasília: MMA, 1998. 1v.

MONTAGNINI F. FANZERES, A.; DA VINHA, S.G. The potencials of 20 indigenous tree species for soil rehabilitation in the atlantic forest region of Bahia, Brazil. Journal of Applied Ecology, v. 32, p. 841-856, 1995.

MORAES, M.L.T.; KAGEYAMA, P.Y.; SEBBENN, A.M.. Correlated mating in dioecious tropical tree species, Myracrodruon urundeuva Fr. All. Forest Genetics, v. 16, p. 23, 2003.

MORI, S. A. Biologia da polinização em Lecythidaceae. Acta Botanica Brasileira, v.1, n. 2, p. 121-124, 1988.

MORI, S. A. Diversificação e conservação das Lecythidaceae Neotropicais. Acta Botânica Brasilieira, v. 4, p. 45-68, 1990.

MORI, S. A. Observações sobre as espécies de Lecythidaceae do leste do Brasil. Boletim de Botânica, v. 14, p. 1-31, 1995. 
MORI, S. A.; PRANCE., G. T. Relações entre a classificação genérica de Lecythidaceae do novo mundo e seus polinizadores e dispersadores. Revista Brasileira de Botânica, v. 4, p. 31-37, 1981.

MORI, S. A.; PRANCE, G.T. Lecitidáceas: família da castanha-do-pará. Rodovia Ilhéus Itabuna: CEPLAC, 1983. 35 p. (Boletim Técnico, 116)

MORI, S. A.; Prance, G.T. Flora Neotropica, Lecythidaceae. New York: Botanical Garden, 1990. 376 p. (Monograph 21).

MORI, S. A.; BOOM, B. M; CARVALHO, A. M.; SANTOS, T. S. Southern Bahian moist forests. The Botanicam Review, v.49, p. 155-288, 1983.

MURAWSKI, D.A. Reproductive biology and genetics of tropical trees from canopy perpective. In: LOWMAN, M.D.; NADKARNI, N.M. (Ed.). Forest canopies. New York: Academic Press, 1995. p. 457-493.

MURAWSKI, D.A.; HAMRICK, J.L. The effect of the density of flowering individuals on the mating systems of nine tropical tree species. Heredity, v. 67, p. 167-174, 1991.

MURAWSKI, D.A.; HAMRICK, J.L.; HUBBELL, S.P. FOSTER, R.B. Mating system of two Bombacaceous trees of a neotropical moist forest. Oecologia, v. 82, p. 501-506, 1990.

NEI, M. F -statistics and analysis of gene diversity in subdividid populations. Annals of Human Genetics, v. 41, p. 225-233, 1977.

NEVES, M. L. C.; PICOLLO, M. R.; ASSIS, M. A.; CHIMICHAQUE, E. R.; SILVA, A. J.; CUNHA, R. P. P. Estudos dos fragmentos da mata atlântica e seu uso para fins comerciais e folclóricos na grande Salvador - Bahia. In: SEMINÁRIO NACIONAL SOBRE RECURSOS FLORESTAIS DA MATA ATLÂNTICA. Sào Paulo, 1999. Anais São Paulo: Editora Gráfica, 1999. 169 p.

NOSS, R. F. Indicators for monitoring biodiversity: a hierachical approach. Conservation Biology, v.4, n.4, p.355-364, Dec.1990. 
O’MALLEY, D.M. ; BAWA, K.S. Mating system of a tropical rain forest tree species. American Journal of Botany, v. 74, n. 8, p. 1143-1149, 1987.

OLIVEIRA, A. M. de. Berimbau: o arco musical da capoeira. Salvador: Imprensa Oficial da Bahia, 1958. (Coleção Antônio Viana, 1).

PERECIN, M. B. Diversidade genética em populações naturais de espécies de espinheira-santa, Maytenus aquifolia MART. e M. ilicifolia Mart. ex Reiss. (Celastraceae). Piracicaba, 2000. 134 p. Tese (Doutorado) - Escola Superior de Agricultura "Luiz de Queiroz", Universidade de São Paulo.

PEREIRA, V. A. A. C. Diversidade genética de Miconia cinnamomifolia (D.C.) Naudin em áreas sob interferência antrópica na Mata Atlântica. Piracicaba, 2002. 84 p. Dissertação (Mestrado) - Escola Superior de Agricultura "Luiz de Queiroz", Universidade de São Paulo.

PERRY, D.J.; BOUSQUET, J. Genetic diversity and mating system of post-fire and porst-harvest black spruce: an investigation using codominat sequence-tagged-site (STS) markers. Canadian Journal Forest Research, v. 31, p. 32-40, 2001.

PRANCE, G. T. The history of INPA capoeira based on ecological studies of Lecythidaceae. Acta Amazônica v.5, n.3, p. 261-263, 1975.

PRANCE, G. T.; MORI, Scott A. Observations on the fruits and seeds of neotropical Lecythidaceae. Brittonia, v. 30, p. 21-33, 1978.

RATNAM; BOYLE, T; Effects of logging and other forms of harvesting on genetic diversity in humid tropical forests. In: YOUNG, A.; BOSHIER, D.; BOYLE, T (Ed.). Forest conservation genetics: principles and practice. AUSTRALIA: CSIRO/CABI, 2000. 352p.

REDFORD, K. H.; C. PADOCH (Ed.). Conservation of neotropical forests: Working From Tradicional Resource Use. Columbia: Columbia University Press, 1992. $476 \mathrm{p}$.

REDFORD, K. H.; RICHTER, B. D. Conservation of biodiversity in world of use. Conservation Biology, v.13.n.6,p.1246-1256, Dec. 1999. 
REIS,A.; FANTINI,A.C.; REIS,M.S.; NODARI,R.O.; GUERRA,M.P. Experiências

silviculturais para o manejo de rendimento sustentado dentro do domínio da Floresta Tropical Atlântica. IN:CONGRESSO FLORESTAL BRASILEIRO. 7., Curitiba 1993. Anais São Paulo: SBS/SBEF, 1993. v.3, p.197-201.

REIS, A.; ZAMBONIM, R. M.; NAKAZONO, E. M. Recuperação de áreas florestais degradadas utilizando a suceesão e as interações planta animal. Santa Catarina: Reserva da Biosfera, 1999. 42 p. (Caderno 14,)

REIS, M.S. Distribuição e dinâmica da variabilidade genética em populações naturais de palmiteiro (Euterpe edulis M.). Piracicaba, 1996. 210 p. Tese (Doutorado) - Escola Superior de Agricultura "Luiz de Queiroz", Universidade de São Paulo.

RIBAS, L. A. Diversidade genética e sistema de cruzamento em populações naturais de duas espécies pioneiras arbóreas. 2003, 102 p. Tese (Doutorado) - Escola Superior de Agricultura “Luiz de Queiroz”, Universidade de São Paulo.

RITLAND, K. Correlated matings in the partial selfer Mimulus guttatus. Evolution, v. 43, n. 4, p. 848-859, 1989.

RITLAND, K.; JAIN, S. A model for the estimation of outcrossing rate and gene frequencies using independent loci. Heredity, v. 47, p. 35-52, 1981.

RITLAND, K. Series of FORTRAN Computer programs for estimating plant mating systems. Journal of Heredity, v. 81, p. 235-237, 1990.

RITLAND, K. Multilocus mating system program MLTR. Version 1.1. Canada: University of Toronto, 1997. 1v.

RITLAND, K.; JAIN, S. A model for the estimation of outcrossing rate and gene frequencies using independent loci. Heredity, v. 47, p. 35-52, 1981.

SAMPSON, J.F. Multiple paternity in Eucalyptus rameliana (Myrtaceae). Heredity, v. 81, p 349-355, 1998.

SANTOS, M. S. S. Relação abelha-flor em comunidade de restinga tropical: sistemas polinizadores de flores melitófilas especializadas. Salvador, 2003. 150p. Dissertação (Mestrado) - Instituto de Biologia, Universidade Federal da Bahia. 
SEBBENN, A. M. Estudo em populações de jequitiba [Cariniana legalis (MART.) KTZE] em teste de progênie por cacacteres quantitativos e isoenzimas. Piracicaba, 2001. 191p. Tese ( Doutorado) - Escola Superior de Agricultura "Luiz de Queiroz", Universidade de São Paulo.

SEBBENN, A.M Depressão por endogamia em jequitiba rosa. Revista do Instituto Florestal, v.13, n.1, p. 61-81, 2001b.

SEBBENN, A.M. Número de árvores matrizes e conceitos genéticos na coleta de sementes para reflorestamentos com espécies nativas. Revista do Instituto Florestal. v. 14, n. 2, p. 115-132, 2002 a.

SEBBENN, A,M. Amostragem para estimativa de frequiências alélicas e índices de diversidade genética em espécies florestais. Revista do Instituto Florestal, v. 14, n. 1, p. 27-38, 2002 b.

SEBBENN, A. M.; SEOANE, C. E. S. KAGEYAMA, P. Y.; VENCOVSKY, R. Efeitos do manejo na estrutura genética de populações de caixeta (Tabebuia cassinoides). Scientia Forestalis, n. 58, 32p, 2000.

SEBBENN, A.M.; KAGEYAMA, P.Y.; SIQUEIRA, A.C.M.F.; ZANATTO, A.C.E. Taxa de cruzamento em populações de Cariniana legalis (Mart.) O. Ktze.: Implicações para a conservação e o melhoramento genético. Scientia Forestalis, n. 58 , p. $25-40,2000$ b.

SEBBENN, A.M.; SEOANA, C.E.S.; KAGEYAMA, P.Y. \& LACERDA, C.M.B. Estrutura genética em populações de Tabebuia cassinoides: Implicações para o manejo florestal e a conservaçao genética. Revista do Instituto Florestal, v. 13, n. 2, p. 93-113, 2001.

SEOANE, C.E.C; SEBBENN, A.M.; KAGEYAMA, P.Y Sistema reprodutivo em populações de Esenbeckia leiocarpa. Revista do Instituto Florestal, v. 13, n. 1, p. 19-26, 2001.

SERPA, A.S.P.; MOREIRA, P.R.; GRACA, P.N.L.; NINSSEN, E.; PASSOS, J.R.S.; VINHA, S.G. Estudo comparativo da vegetação em três estágios de sucessão e determinação da área mínima de amostragem para levantamento florístico na estação ecológica do pau-brasil, Bahia. Curitiba: UFPR, 1986. 24p. 
SHAFFER, K. O Berimbaude-barriga e seus toques. Rio de Janeiro: FUNARTE., 1977. (Monografias folclóricas 2). 1v.

SIMÕES,L.L.; LINO,C.F Sustentável mata atlântica: a exploração de seus recursos florestais. São Paulo: SENAC, 2002. 215p.

SOUZA, A. L., MEIRA-NETO, J. A. A.; SCHETTINO, S. Avaliação fitossociológica.

Viçosa: Convênio Sociedade de Investigação Florestais/ Bahia Sul Celulose S. A., Viçosa, MG, 1996. 1v. (Relatório final)

SOUZA,L.M.F.I.; KAGEYAMA,P.Y.; SEBBENN,A.M. Sistema de reprodução em população natural de Chorisia speciosa A. St.-Hil (Bombacaceae). Revista Brasileira de Botânica, v.26, n.1, p.113-121, 2003.

STEVENSON, P. R. The relathionship between fruit production and primate abundance in neotropical communities. Biological Journal of the Linnean Society, n. 72, p. 161-178, 2001.

SUN, M.; RITLAND, K. Mating system of yellow starthistle (Centaurea solstitialis), a successful colonizer in North America. Heredity, v. 80, p. 225-232, 1998.

SWOFFORD, D.L.; SELANDER, R.B. BIOSYS-1. A FORTRAN computer program for the analysis of allelic variation in population genetics and biochemical systematics. Journal of Heredity, v. 72, p. 282-283, 1989.

TEIXEIRA, C. S. Florestas Sociais - Uma resposta à destruição das florestas tropicais? Rio de Janeiro, 2001. 172 p. Dissertação ( Mestrado) - Instituto de Ciências Humanas e Sociais, Universidade Federal Rural do Rio de Janeiro.

VENCOVSKY R.;; BARRIGA, R., Genética biométrica no fitomelhoramento. Ribeirão Preto: Sociedade Brasileira de Genética, 1992. 486p.

WEIR, B.S. Intraspecific differentiation. In: HILLIS, D.M.; MORITZ, SINAUER, C. (Ed.). Molecular Systematics. Sunderland, MA: , 1990. p. 373-410.

WEIR, B.S. Genetic data analysis II. Methods for discrete population genetic data. Suderland: Sinauer, 1996. 445 p.

WEIR, B.S; REYNOLDS, J.; DODDS, K.G. The variance of sample heterozygosity.

Theoretical Population Biology, v. 37, p. 235-353, 1990. 
WORKMAN, P.; NISWANDER, J.L. Population studies on southwestern Indian Tribes.

II. Local genetic differentiation in the Papago. American Journal Human Genetic, v. 22, p. 24-49, 1970.

WRIGHT, S. Evolution and the genetics of populations . Variability within and among natural populations. Chicago: University of Chicago Press, v. 4, 1978, 423 p.

YEH, F. C. Isozyme analylis for revealing population struture for usoe in breeding strategies. In : GIBSON, G. L.; GRIFFIN, A. R.; MATHESON, A. C. (Ed.). Breeding tropical trees: population and genetic improvement strategy clonal and seedling forestry. Pattaya: Oxford Institute, 1988, p. 119-131.

ZUCCHI, M. I. Análise da Estrutura Genética de Eugenia dysenterica DC utilizando Marcadores RAPD e SSR. Piracicaba, 2002. 130p. Tese (Doutorado) Escola superior de Agricultura "Luiz de Queiroz", Universidade de São Paulo. 